
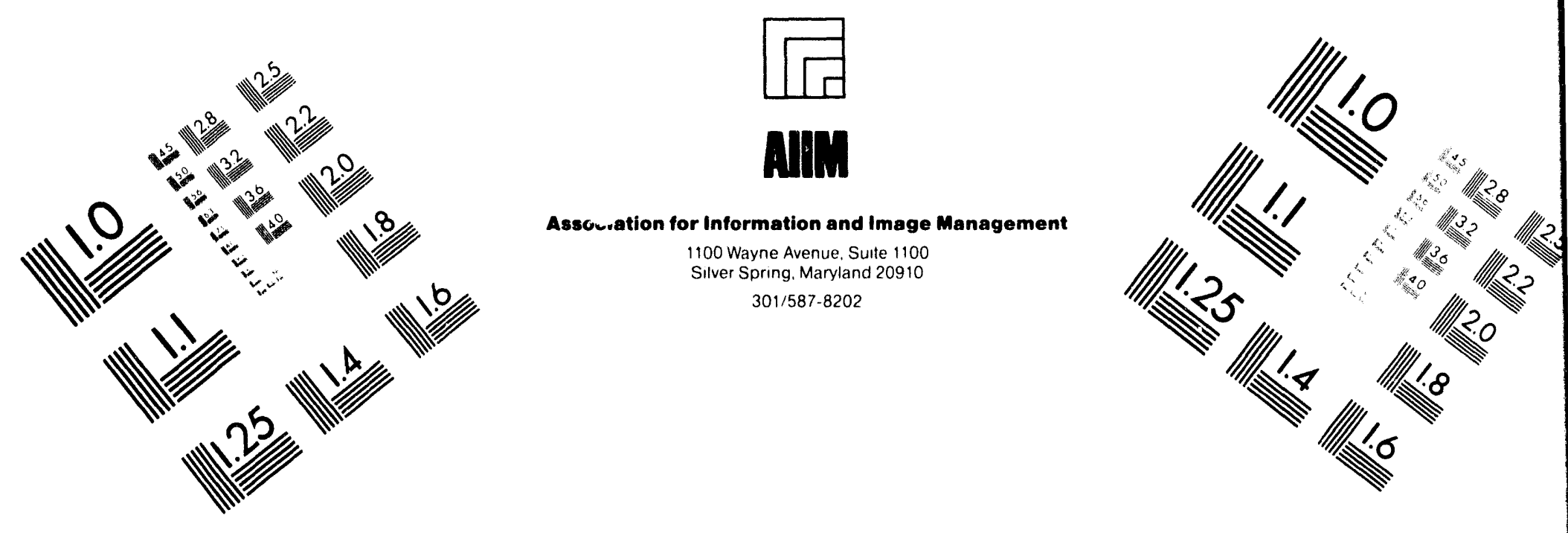

\title{
Centimeter
}

$\begin{array}{llllllllllllllll}1 & 2 & 3 & 4 & 5 & 6 & 7 & 8 & 9 & 10 & 11 & 12 & 13 & 14 & 15 & \mathrm{~mm}\end{array}$

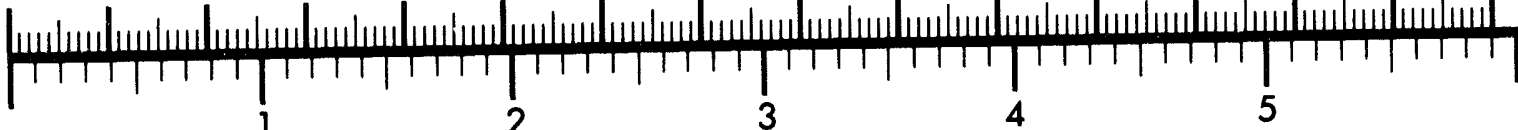
Inches
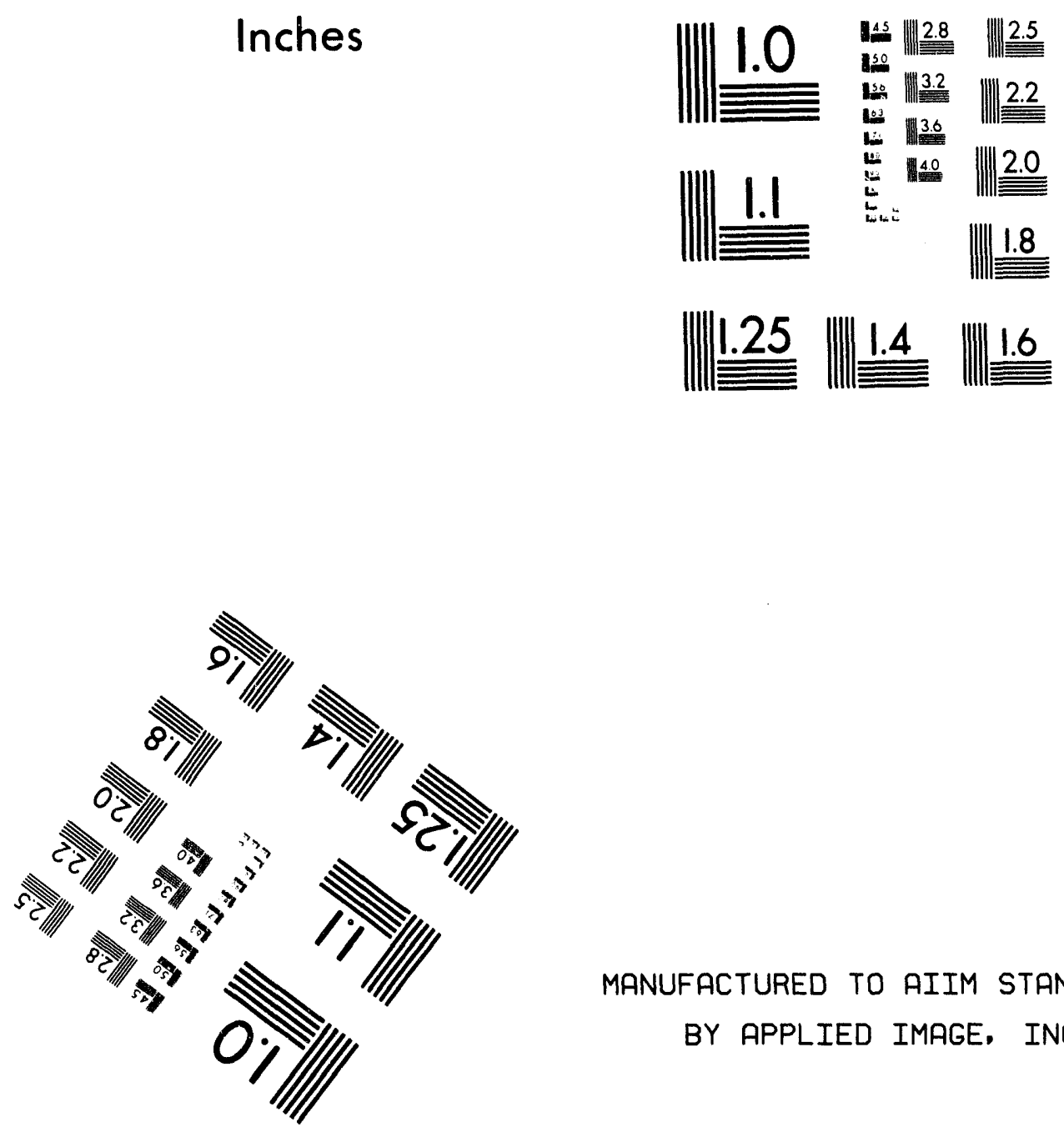

MANUFACTURED TO AIIM STANDARDS

BY APPLIED IMAGE, INC.

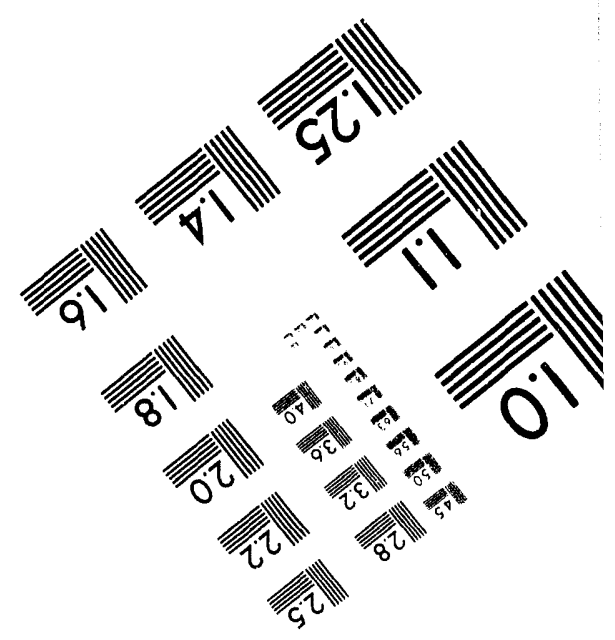



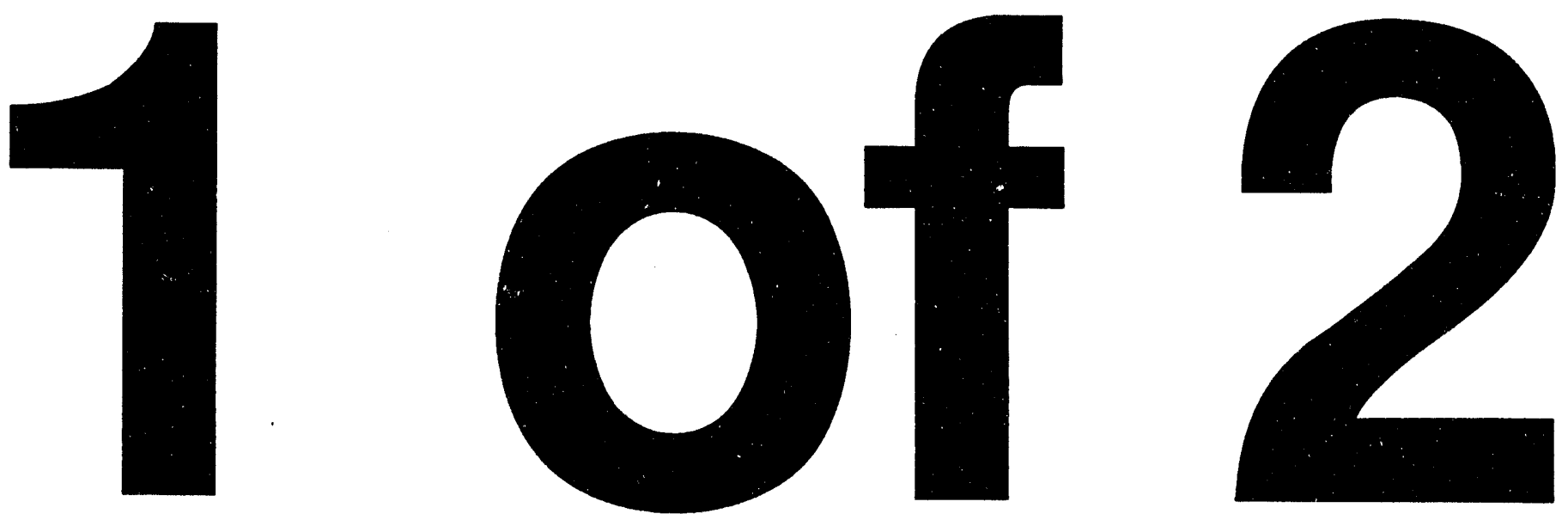


\title{
Volume I \\ Phase I of the North Site Cleanup: Definition of Product Streams
}

Topical Report

Susan Sorini

Norm Merriam

Work Performed Under Cooperative Agreement No.: DE-FC21-93MC30126

\author{
For \\ U.S. Department of Energy \\ Office of Fossil Energy \\ Morgantown Energy Technology Center \\ P.O. Box 880 \\ Morgantown, West Virginia 26507-0880
}

By
Western Research Institute
Box 3395
Laramie, Wyoming 82071

March 1994 
LIST OF TABLES.

Page

LIST OF FIGURES......................................................................................................... viii

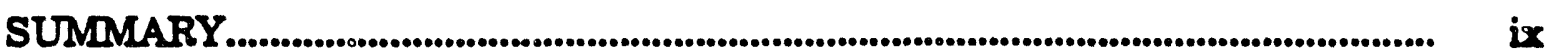

INTRODUCTION..................................................................................................................... 1

Background........................................................................................................ 1

North Site Materials........................................................................................................ 1

DESCRIPTION OF THE WORK...............................................................................

Phase I Objective................................................................................................................ 2

Phase I Plan....................................................................................................................... 2

North Site Product Streams and Composite Groups........................................... 2

North Site Sampling....................................................................................................... 5

Preparation of Composite Samples for A:alysis................................................... 18

Analysis of North Site Samples............................................................................... 23

Analytical Methods......................................................................................................... 32

North Site Materials Handling Data Base............................................................. 38

Photographs..................................................................................................................................... 38

RESULTS AND DISCUSSION................................................................................ 39

Results from TCLP Extractions of Composite and Individual

Samples................................................................................................................ 39

TCLP QA/QC Results................................................................................................. 48

Btu Characterization of the Unprocessed Tar Sand,

Unprocessed Coal, and Raw Oil Shale Streams...................................... $\quad 52$

Characterization of the North Site Waters....................................................... 52

Results from Analysis of the Tars, Oils, and Hydrocarbon Liquids............ 65

Analysis of the North Site Chemicals and Unknown Materials.................... $\quad 75$

Results frem Analysis of the Field Equipment Blanks.......................................... $\quad 77$

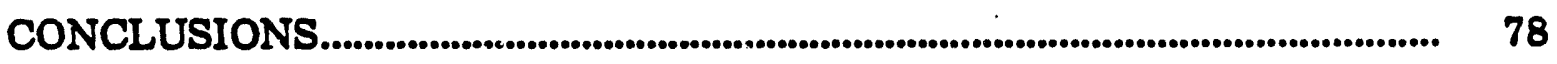

NORTH SITE MATERIALS HANDLING DATA BASE......................................... 87

North Site Materials File (HAZMAT.DBF) ............................................................ 87

Composite Group File (COMPGRP.DBF) ......................................................... 88

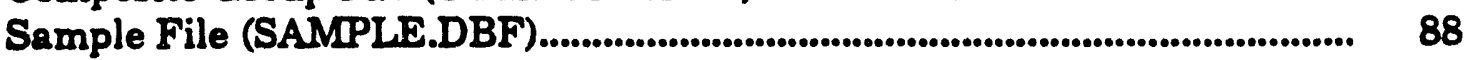

Analysis File (ANALYSIS.DBF) .......................................................................... 89

Results File (RESULTS.DBF)..................................................................................... 90

Regulatory Analyte File (REGLEVEL.DBF)..................................................... 91

Label File (POPUP.DBF)................................................................................ 91

Data Base Reports........................................................................................................... 91

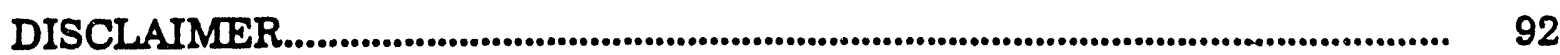

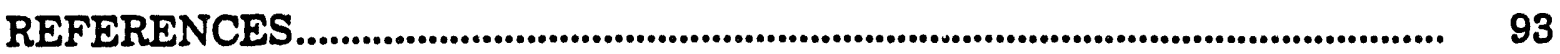




\section{TABLE OF CONTENTS \\ VOLUME II}

Appendix A. Inventory of North Site Materials Requiring Characterization

Appendix B. Copies of Phase I Project Logbooks

Appendix C. Copies of Sample Chain-of-Custody Forms

Appendix D. Photographs

Appendix E. Copies of Data Report Forms Received for Analysis of Phase I Samples

Appendix F. Examples of Data Base Reports 


\section{IST OF TABLES}

Table

$\underline{\text { Page }}$

1. North Site Cleanup Product Streams and Composite Groups.................. 3

2. Composite Groups, Containers Sampled, and Containers Represented in the North Site Unprocessed Tar Sand Stream.

3. Composite Groups, Containers Sampled, and Containers Represented in the North Site Unprocessed Coal Stream.

4. Composite Groups, Containers Sampled, and Containers Represented in the North Site Raw Oil Shale Stream.

5. Composite Groups, Containers Sampled, and Containers Represented in the North Site Spent Oil Shale, Processed Tar Sand, Activated Charcoal Stream

6. Composite Groups, Containers Sampled, and Containers Represented in the North Site Miscellaneous Material Stream

7. Composite Groups, Containers Sampled, and Containers Represented in the North Site Water Stream

8. Composite Groups, Containers Sampled, and Containers Represented in the North Site Tar, Oil, and Hydrocarbon Liquid Stream.

9. Composite Groups, Containers Sampled, and Containers Represented in the North Site Unknown Material Stream

10. Composite Groups, Containers Sampled, and Containers Represented in the North Site Chemical Stream.

11. Sampling Equipment Used in Phase I of the North Site Cleanup Project

12. North Site Sampling Field Trip Blanks and Composite Groups Sampled.

13. Composite Samples Prepared for Analysis in Phase I of the North Site Cleanup Project.

14. North Site Sample Characterization.

15. Composite Samples and Individual Samples Requiring Analysis in Phase I of the North Site Cleanup Project. 


\section{LIST OF TABLES}

(continued)

16. Toxicity Characteristic Constituents, Regulatory Levels, Analytical Method Numbers, and Hazardous Waste Numbers.................

17. Characterization of North Site Composite and Individual Samples by TCLP Extraction.

18. Concentrations of the Regulated Metals in the TCLP Extracts of the North Site Materials.

19. Analytical Detection Limits for Metals Analyses of the North Site TCLP Extracts.

20. Analytical Detection Limits for Semivolatile Organic Analyses of the North Site TCLP Extracts.

21. Analytical Detection Limits for Volatile Organic Analyses of the North Site TCLP Extracts.

22. Concentrations of the TCLP Regulated Analytes in TCLP Extracts of the Tar Sand Sludge Sample and Tar Sand Sludge Sample Split.

23. Concentrations of the TCLP Regulated Analytes in TCLP Extracts of the Crushed KC Rock Sample and Crushed KC Rock Sample Split........ $\quad 50$

24. Concentrations of the TCLP Regulated Analytes in TCLP Extracts of the Oil Pitch Composite and Oil Pitch Composite Split.

25. Btu Content of Unprocessed Tar Sand, Unprocessed Coal, and Raw Oil Shale Samples

26. pH Values of the North Site Waters...................................................................

27. Concentrations of the TCLP Regulated Analytes in the North Site Retort Water and Graham Water.

28. Concentrations of the TCLP Regulated Analytes in the North Site Tank Cleanout Water and Water Scavenger

29. Concentrations of the TCLP Regulated Analytes in the North Site Unidentified UCG Water and Hoe Creek Water.

30. Concentrations of the TCLP Regulated Analytes in the North Site Tank Bottom Water and Sludgy Water. 


\section{LST OF TABLES \\ (continued)}

\section{Table}

Page

31. Concentrations of the TCLP Regulated Analytes in the North Site Treolite Distillates and Free and Distilled Water.

32. Concentrations of the TCLP Regulated Analytes in the North Site

RMI Water and CROW Water.

33. Concentrations of the TCLP Regulated Analytes in the North Site Water, Coal Fines, Oil Sample.

34. TCLP Pass/Fail Resulto for the North Site Water Stream Based on Total Concentration of TCLP Regulated Analytes in the Water........

35. Composite Groups in the North Site Water Stream Failing

TCLP Regulatory Lovels.

36. Concentrations of Benzene in Composite and Individual Samples of the Tar, Oil, and Hydrocarbon Liquid Stream.

37. Concentrations of Benzene in Composite and Individual Samples of the Tar, Oil, and Hydrocarbon Liquid Stream Divided by

a Dilution Factor of 20

38. TCLP Regulated Metal Concentrations in the North Site

Tar, Oil, and Hydrocarbon Liquid Stream.

39. Metal Concentrations in the Dirty Oil and Sludge, Coal Tar, and Tank Cleanout Oil Composite Samples Determined by SVL Analytical and WRI.

40. Flash Point Values for the Shale Oil Distillate Samples and the Distillate Light Oil Composite Sample.

41. Hazard Classification for the Tars, Oils, and Hydrocarbon Liquids.

42. QA/QC Data from Analyses of a Coal Tar Composite and Its Blind Split.

43. Inorganic Characterization of the North Site Chemicals and Unknown Materials.

44. TCLP Regulated Metal Concentrations in the North Site

Unknown Materials and Chemicals.

45. Hazard Classification of the North Site Composite Groups 


\section{IST OF FIGURES}

Figure Page

1. North Site Material Characterization................................................................ 24 


\section{SUMAMARY}

Various materials and equipment have accumulated at the Western Research Institute (WRI) North Site Facility since its commissioning in 1968. This facility was built by the U.S. Bureau of Mines, transferred to the U.S. Energy Research Development Administration (ERDA) in 1976, and transferred once again to the U.S. Department of Energy (DOE) shortly thereafter. In 1983, the North Site Facility became part of WRI. The materials that have accumulated over the years at the site have been stored in drums, tanks, and open piles. They vary from oil shale, tar sand, and coal feedstocks to products and materials associated with in situ simulation and surface process developments associated with these feedstocks. The majority of these materials have been associated with DOE North Site activities and work performed at the North Site under DOE-WRI cooperative agreement contracts. In phase I of the North Site Facility cleanup project, these materials were sampled and evaluated to determine their chemical characteristics for proper disposal or use in accordance with current local, state, and federal regulations.

Phase I of the North Site Facility cleanup project involved dividing the stored materials into product streams and dividing each product stream into composite groups. Composite groups contain materials known to be similar in composition, source, and process exposure. For each composite group, materials, which are representative of the composite, were selected for sampling, compositing, and analysis.

Sampling was performed by WRI personnel. The sampling methods and equipment that were used varied depending upon the nature of the material. To reduce analytical costs, many of the samples were composited prior to analysis. Most of the sample composites and individual samples were characterized for toxicity by the Toxicity Characteristic Leaching Procedure (TCLP) or by direct analysis for the TCLP regulated analytes. Samples were analyzed at WRI. However, to verify WRI results and for Quality Assurance/Quality Control (QA/QC) purposes, many samples were also analyzed by a Contract Laboratory Program

(CLP) laboratory currently under contract with the U.S. Environmental Protection Agency (EPA).

In phase I, chain-of-custody procedures were followed to ensure the integrity of the samples from time of collection to data reporting. In addition, for QA/QC purposes, field trip blanks and equipment blanks were analyzed, as well as, TCLP equipment and method blanks. Split samples were also prepared and analyzed as a check on data quality. 
Data from analysis of the North Site samples provide information on the identity and composition of the materials in each of the product streams, as well as, their hazard classification. Sixty-nine composite or individual samples were characterized. Forty-one of these were determined to be nonhazardous, and 28 were determined to be hazardous based on the hazard characteristic of toxicity. Two of the composite groups that fail toxicity also fail the hazard characteristic of ignitability. Most of the composite groups that were determined to be hazardous are oily materials that contain high concentrations of benzene. This information will now be used in phases II and III of the North Site cleanup project, which involve disposal or use of the North Site materials.

To track materials in the North Site cleanup project, the North Site Materials Handling Data Base was created. This data base contains an inventory of the materials requiring disposal or use, as well as, the product stream to which the material belongs, composite information, sampling and analytical information, analytical data, and hazard classification. This data base allows tracking of a material listed in the North Site inventory through the sampling and analytical processes, to a decision on hazard classification, and finally, when the project is completed, it will contain information on disposal or use of the material. 


\section{INTRODUCTION}

\section{Background}

The Western Research Institute (WRI) North Site Facility was established in 1968 when the U.S. Bureau of Mines sought to conduct large-scale tests simulating underground retorting of oil shale. A 150-ton retort was constructed in 1968 on land leased from Upland Industries (the real estate arm of Union Pacific Railroad). A control room, shops, an office building, and a laboratory were also built during that first year. A 10-ton retort was relocated from the center to the North Site in 1969, and several small storage buildings have been added over the years.

In 1976, the facility was transferred to the U.S. Energy Research Development Administration (ERDA) as part of the Laramie Energy Research Center (LERC), and then shortly thereafter, it was transferred to the U.S. Department of Energy (DOE) and became the Laramie Energy Technology Center (LETC). In 1983, the North Site Facility became part of WRI as LETC was defederalized and became a corporation of the University of Wyoming. Over the years, a core storage building and an in situ processing laboratory were added to the North Site Facility, along with two buildings which were relocated from the LETC tar sand site near Vernal, Utah. One of these buildings is currently used as a coal processing laboratory, and the other is used for storage of materials. In 1989, the core storage building was converted to house the mild gasification pilot plant. Over the years, in addition to buildings being added to the North Site, various materials and equipment have accumulated and now require disposition or use as part of the North Site cleanup project.

\section{North Site Materials}

Materials that have accumulated over the years at the North Site are stored in crums, tanks, and open piles and are distributed throughout the site. They vary : om oil shale, tar sand, and coal feedstocks to products and materials associated with these feedstocks. Containers of the various materials range in size from less than one gallon to 55 gallons. Most of these are stored outside on pallets and are exposed to the weather. In addition, there are a storage tank containing approximately 13,000 gallons of oil/water mixture and four other storage/mixing tanks that do not contain liquid but their inner walls are coated with residue. Also, the 150-ton and 10-ton in situ simulation retorts remain on site and require decontamination and disposal. The majority of the materials described above have been associated with DOE North Site activities and work performed at the North Site under DOE-WRI cooperative agreement contracts. The WRI North Site was audited by the U.S. DOE Tiger Team in 1991 as part of an audit of DOE Fossil Energy test sites in Wyoming. Numerous questions were raised relating to storage and disposition of the materials. The Tiger Team emphasized the need to initiate a North Site cleanup activity. As a result, a five-phase project is being performed to cleanup the WRI North Site Facility. The subject of this report is phase I of the cleanup, which involves defining the North Site product streams. 
In 1991, the North Site materials were inventoried and each container, tank, pile, etc. was given a serial number, which was entered into a data base. At the start of phase I of this project, an inventory of the materials requiring disposition or use was prepared and entered into the North Site Materials Handling Date Base for tracking of the materials throughout the phases of this project.

\section{DESCRIPIION OF THE WORK}

\section{Phase I Objective}

The objective of phase I of the North Site cleanup project was to define the various product streams requiring disposal or use. This was accomplished by sampling and analyzing the materials to obtain information for: (1) use in determining which materials can be useful products and which can not be used; (2) use in determining which materials are hazardous and which are not hazardous; and (3) use in determining what methods of disposition can be used for each respective material.

\section{Phase I Plan}

The plan for phase I of the North Site Facility cleanup project (Merriam and Sorini 1993) called for the following activities to be performed.

1. Dividing the North Site materials inventory into product streams and composite groups

2. Sampling the product streams

3. Preparing composite samples

4. Analyzing composite samples and individual samples from the North Site product streams

5. Determining hazardous/nonhazardous classification for each of the materials

6. Developing and using a materials handling data base

\section{North Site Product Streams and Composite Groups}

The inventory of North Site materials requiring disposal or use is given in Appendix A (Appendices can be found in Volume II). The materials listed in this inventory were divided into product streams and composite groups. The composite groups contain materials known to be similar in composition, source, and process exposure. The North Site product streams and their composite groups are listed in Table 1. 
Table 1. North Site Cleanup Product Streams and Composite Groups

\begin{tabular}{|c|c|}
\hline Product Stream & Composite Groups \\
\hline Unprocessed Tar Sands & $\begin{array}{l}\text { Tar Sand } \\
\text { Tar Sand Sludge }\end{array}$ \\
\hline Unprocessed Conls & $\begin{array}{l}\text { Unprocessed Western Coal } \\
\text { Unprocessed Eastern Coal }\end{array}$ \\
\hline Raw Oil Shales & $\begin{array}{l}\text { Raw Western Oil Shale } \\
\text { Raw Eastern Oil Shale } \\
\text { Raw Shale Pile }\end{array}$ \\
\hline $\begin{array}{l}\text { Spent Oil Shale, Processed } \\
\text { Tar Sand, Activated Charcoal }\end{array}$ & $\begin{array}{l}\text { Spent Oil Shale-1 } \\
\text { Spent Oil Shale-2 } \\
\text { Spent Oil Shale Pile } \\
\text { Spent Tar Sand } \\
\text { Activated Charcoal } \\
\text { Unused Activated Charcoal } \\
\text { MG Fines, Char }\end{array}$ \\
\hline Miscellaneoun Materials & $\begin{array}{l}\text { Oily Insulation } \\
\text { Tank Bottom Liner } \\
\text { Evaporation Tank Bottom Dirt } \\
\text { Oily Dirt } \\
\text { Sulfur } \\
\text { Crushod KC Rock } \\
\text { Fly Ash }\end{array}$ \\
\hline Waters & $\begin{array}{l}\text { Retort Water } \\
\text { Graham Water } \\
\text { Tank Cleanout Water } \\
\text { Water Scavenger } \\
\text { Water, Coal Fines, Oil } \\
\text { Unidentified UCG Water } \\
\text { Hoe Creek Water } \\
\text { RM1 Water } \\
\text { CROW Water } \\
\text { Tank Bottom Water } \\
\text { Sludgy Water } \\
\text { Treolite Distillates } \\
\text { Free \& Distilled Water }\end{array}$ \\
\hline
\end{tabular}


Table 1. North Site Cleanup Product Streams and Composite Groups (continued)

Product Stream

Composite Groups

Tars, Oils, \& Hydrocarbon

Liquids

Unknown Materials

Pellets

Unknown Liquid

Unknown Material

SAI Comp Material-Liquid

SAI Comp Material-Solid

Artic 75/90

Chlorinated Solvents

Chemicals

Monoethanloamine

Tretolite

Ceustic Soda

Boiler Water Treatment

Dry Water Treatment-1

Dry Water Treatment-2

Soda Ash 


\section{North Site Sampling}

\section{Materials Sampled}

For each composite group, materials, which are representative of the composite, were selected for sampling. As shown in Appendix A, each container, tank, pile, etc. of material stored at the North Site has a serial number. Listed in Tables 2 through 10 are the serial numbers of the containers that were sampled for each composite group, along with the serial numbers of the containers that are represented by each composite group.

Table 2. Composite Groups, Containers Sampled, and Containers Represented in the North Site Unproceceed Tar Sand Stream

Composite Groups Containers Sampled Containers Represented

Tar Sand

$19,28,45,51,57,65$ 235,1159
$14-48,50-54,56-63,65$, 221-223, 226-240, 862-885, 1159,1160

Tar Sand Sludge

49

49

Table 3. Composite Grorps, Containers Sampled, and Containers Represented in the North Site Unprocessed Coal Stream

Composite Groups Containers Sempled Containers Represented

Unprocessed

Western Coal

Unprocessed

Eastern Coal
$83,213,217,372,1163$

83-94, 97-114, 116, 117, 119-138, 213-220, 372, 553-560, 567-569, 573, 574, 812-814, 939-942, 983, 988, $990,1070,1071,1161-1166$

$1-4,95,96,115,201-212$, $810,811,1212$ 
Table 4. Composite Groups, Containers Sampled, and Containers Represented in the North Site Raw Oil Shale Stream

\begin{tabular}{lll} 
Composite Groups & Containers Sampled & Containers Represented \\
\hline $\begin{array}{l}\text { Raw Western } \\
\text { Oil Shale }\end{array}$ & $139,247,395,460$ & $\begin{array}{l}139-161,241-277,374-406, \\
409-421,424-434,436-473, \\
547-549,815,816\end{array}$ \\
Raw Eastern & & $162-180,182,183,185-200$, \\
Oil Shale & $196,200,358,1167$ & $337-343,354-362,407,408$, \\
& & $855,856,1167$
\end{tabular}

Table 5. Composite Groups, Containers Sampled, and Containers Represented in the North Site Spent Oil Shale, Processed Tar Sand, Activated Charcoal Stream

Composite Groups Containers Sampled Containers Represented

Spent Oil Shale-1

$330,367,541,546,818$

818

Spent Oil Shale-2

1080,1081

1080,1081

Spent Oil

1259,1261

1259,1261

Shale Pile

Spent Tar Sand

370,373

368-371, 373

Activated

$684,690,700,826,830$,

Charcoal

$835,840,845,850,1170$

684-702, 826-838, 840-852,

$1170,1226,1227$

Unused Activated

859

859,860

Charcoal

MG Fines, Char

$1204,1205,1217,1223$, 1257

1204-1211, 1213-1219, 1221-1225, 1257 
Table 6. Composite Groups, Containers Sampled, and Containers Represented in the North Site Miscellaneous Material Stream

\begin{tabular}{lll}
\hline Composite Groups & Containers Sampled & Containers Represented \\
\hline Oily Insulation & 948 & 948,949 \\
Tank Bottom Liner & 820,823 & $820,821,823$ \\
Evaporation & 1244,1245 & $933,1244,1245$ \\
Tank Bottom Dirt & & \\
Oily Dirt & $645,655,999$ & $645-655,999$ \\
Sulfur & 950 & 950 \\
Crushed KC Rock & 1121 & 1121 \\
Fly Ash & $891-912$ & $891-912$ \\
\hline
\end{tabular}

Table 7. Composite Groups, Containers Sampled, and Containers Represented in the North Site Water Stream

\begin{tabular}{lll}
\hline Composite Groups & Containers Sampled & Containers Represented \\
\hline Retort Water & $350,1079,1122$ & $350,1079,1122$ \\
Graham Water & 1113,1120 & $1113-1120$ \\
Tank Cleanout Water: & 931,944 & 931,944 \\
Water Scavenger & 494 & $493-495$ \\
Water, Coal Fines, Oil & 1198 & 1198 \\
Unidentified UCG Water & 1271 & 1271 \\
Hoe Creek Water & 1273 & 1273 \\
RM1 Water & 1272 & 1272 \\
CROW Water & 1267,1268 & 1267,1268 \\
Tank Bottom Water & $824,889,947$ & $824,825,889,947$ \\
Sludgy Water & 550 & 550 \\
Treolite Distillates & 618 & 618 \\
Free \& Distilled Water & 1201 & 1201 \\
\hline
\end{tabular}


Table 8. Composite Groups, Containers Sampled, and Containers Represented in the North Site Tar, Oil, and Hydrocarbon Liquid Stream

Composite Groups

Tank Bottom

Heavy Oil Solid

Oil Pitch

Shale Cil-1

Shale Oil-2

Shale Oil-3

Shale Oil Distillates

Tar Sand Heavy Oil

Heavy Oil Plus Coal

Dirty Oil \& Sludge

Coal Tar.

Heavy Oil

Heavy Fuel Oil

Heavy Crude Oil

Tank Bottom

Tank Water

Tank Oil

Distillate Light Oil

Tank Cleanout

Tank Cleanout Oil

Oily Material Plus Water

Tank Bottom Heavy Oil
Containers Sempled

$55,643,890$

953, 975, 976, 1258

279, 282, 293, 298, $301,319,322$

344,346

776, 777, 779, 781, 783

$614,615,656$

$64,498,577,599$, 1139,1141

$474,476,500,502$

$785,795,858$

$482,959,961,963,965$, $967,969,973,1135-1138$

$66,305,489,490,937$

$6,7,9,10,11,12$

787, 792, 793

943, 957, 958, 978

1265

1266

1199,1200

623

619

$600,602,604,606,609$

$627,888,929$
Containers Represented

$55,643,890$

951-956, 975, 976, 1258

$279,282,293,294,295$, 298, 299, 301, 319, 320, 322

$344,346-348$

776-784

$614,615,656$

64, 498, 577-599, 1139,1141

474-477, 500-502

$785,794,795,858$

$482,959-974,1135 \cdot 1138$

$66,305,489,490,491,937$

$6,7,9,10,11,12$

787, 792, 793

943, 957, 958, 978

1265

1266

1199, 1200

623

619,620

600-610, 945

627-642, 886-888, 929, 930 
Table 8. Composite Groups, Containers Sampled, and Containers Represented in the North Site Unknown Material Stream

\begin{tabular}{lll}
\hline Composite Groups & Containers Sampled & Containers Represented \\
\hline Pellets & $518,519,620$ & $518,519,520,552$ \\
Untenown Liquid & 496 & 496 \\
Untenown Material & 992,993 & 992,993 \\
SAI Comp & 1067 & 1067,1068 \\
Material-Liquid & & 1140 \\
SAI Comp & & \\
Material-Solid & 1140 & 853,854 \\
Artic 75/90 & 853 & 1074 \\
Chlorinated & Not Sampled & \\
Solvents & & \\
\hline
\end{tabular}

Table 10. Composite Groups, Containere Sampled, and Containers Represented in the North Site Chomical Stream

\begin{tabular}{lll}
\hline Composite Groups & Containers Sampled & Containers Represented \\
\hline Monoethanolamine & 487 & 487 \\
Tretolite & 852,617 & 352,617 \\
Caustic Soda & 808 & 803,804 \\
$\begin{array}{l}\text { Boiler Water } \\
\text { Treatment }\end{array}$ & 805 & 805 \\
$\begin{array}{l}\text { Dry Water } \\
\text { Treatment-1 }\end{array}$ & 806 & 806 \\
$\begin{array}{l}\text { Dry Water } \\
\text { Treatment-2 }\end{array}$ & 807 & 807,808 \\
Soda Ash & 92 & 92 \\
\hline
\end{tabular}




\section{Sempling Methods and Equipment}

A variety of physical forms of materials required sampling as part of phase I of this cleanup project. These included liquids, viscous liquids, multiphasic liquids, and solids stored in a variety of ways (i.e., various sized drums, piles, tanks, etc.). The first step in preparing for sampling was to visually inspect the materials to determine the type of sampling method and type of equipment to be used. Sampling equipment and methods were selected or designed based on specific site and material conditions. Information presented in Chapter 9 of SW-846 (U.S. EPA 1986) was used as guidance for selecting appropriate sampling equipment, and guidance given in American Society for Testing and Materials (ASTM) methods for sampling various matrices was used in sampling the North Site materials.

If possible, contents of containers were mixed prior to sampling. Some of the materials were difficult to mix, such as hard or sticky materials packed in 55-gallon irums. The sampling devices used to collect individual samples and samples used to prepare composite samples for the various North Site product streams are listed in Table 11. Copies of the pages from the sampling logbook describing the sampling activities are contained in Appendix B.

Disposable glass coliwasas and disposable, sterile sampling scoops were the sampling equipment that was most often used. These were very suitable because of their appropriateness to the material matrices and storage containers, ease of use under the environmental sampling conditions, and disposable characteristic, which prevents cross-contamination from one sample to the next.

The coliwasa is a device for sampling free-nlowing liquids and slurries contained in drums, shallow tanks, pits, and similar containers. It is especially useful for sampling materials consisting of several immiscible liquid phases (Chapter 9, SW-846, U.S. EPA 1986). Disposable glass coliwasas were used to sample many of the materials listed in Table 11. In addition, Teflon liquid/sludge coliwasa tubes were used for some of the viscous and sludgy materials listed under the tar, oil, and hydrocarbon liquid stream. A coliwase consists of a tube equipped with an end closure that can be opened and closed while the tube is submerged in the material.

Disposable scoops were used to sample most of the dry, sticky, and sludgy materials; however, a grain sampler (thien) was used to sample the fly ash materials. This device consists of two slotted concentric tubes, with the outer tube having a pointed tip to penetrate the material being sampled. The inner tube is rotated to open and close the sampler. These devices are best for sampling dry granules or powdered material having a very small particle size. 
Table 11. Sampling Equipment Used in Phase I of the North Site Cleanup Project

$\begin{array}{lll}\text { Product Stream Sample Sampling Equipment } & \text { Sam }\end{array}$

\begin{tabular}{|c|c|c|}
\hline $\begin{array}{l}\text { Unprocessed } \\
\text { Tar Sands }\end{array}$ & $\begin{array}{l}\text { Tar Sand } \\
\text { Tar Sand Sludge }\end{array}$ & $\begin{array}{l}\text { Disposable Scoop } \\
\text { Disposable Scoop }\end{array}$ \\
\hline $\begin{array}{l}\text { Unprocessed } \\
\text { Cosls }\end{array}$ & $\begin{array}{l}\text { Unprocessed Western } \\
\text { Coal } \\
\text { Unprocessed Enstorn } \\
\text { Coal }\end{array}$ & $\begin{array}{l}\text { Disposable Scoop } \\
\text { Disposable Scoop }\end{array}$ \\
\hline Raw Oil Shales & $\begin{array}{l}\text { Raw Western Oil Shale } \\
\text { Raw Eastern Oil Shale } \\
\text { Raw Shale Pile }\end{array}$ & $\begin{array}{l}\text { Disposable Scoop } \\
\text { Disposable Scoop } \\
\text { Gloved Hand as Scoop }\end{array}$ \\
\hline $\begin{array}{l}\text { Spent Oil Shale, } \\
\text { 'rocessed Tar Sand, } \\
\text { Activatod Chareoal }\end{array}$ & $\begin{array}{l}\text { Spent Oil Shale-1 } \\
\text { Spent Oil Shale-2 } \\
\text { Spent Oil Shale Pile } \\
\text { Spent Tar Sand } \\
\text { Activated Chareoal } \\
\text { Unused Activated } \\
\text { Charcoal } \\
\text { MG Fines, Char }\end{array}$ & $\begin{array}{l}\text { Disposable Scoop } \\
\text { Disposable Scoop } \\
\text { Disposable Scoop } \\
\text { Disposable Scoop } \\
\text { Disposable Scoop } \\
\text { Disposable Scoop } \\
\text { Disposable Scoop }\end{array}$ \\
\hline $\begin{array}{l}\text { Miscellanoous } \\
\text { Materials }\end{array}$ & $\begin{array}{l}\text { Evaporation Tank } \\
\text { Bottom Dirt } \\
\text { Oily Dirt } \\
\text { Sulfur } \\
\text { Crushod KC Rock } \\
\text { Fly Ash }\end{array}$ & $\begin{array}{l}\text { Disposable Scoop } \\
\text { Disposable Scoop } \\
\text { (Sample was in large } \\
\text { sheets, which were } \\
\text { lifted out of the drum } \\
\text { with the scoop and then } \\
\text { cut into strips for } \\
\text { addition to the sample } \\
\text { bottle. } \\
\text { Disposable Scoop } \\
\text { Disposable Scoop } \\
\text { Disposable Scoop } \\
\text { Disposable Scoop } \\
\text { Grain Sampler (Thien) }\end{array}$ \\
\hline
\end{tabular}


Table 11. Sampling Equipment Uned in Phase I of the North Site Cleanup Project (oontinued)

\begin{tabular}{|c|c|c|}
\hline Product Stream & Sample & Sampling Equipment \\
\hline Waters & $\begin{array}{l}\text { Retort Water } \\
\text { Graham Water } \\
\text { Tank Cleanout Water } \\
\text { Water Scavenger } \\
\text { Water, Coal Fines, Oil } \\
\text { Unidentified UCG Water } \\
\text { Hoe Creek Water } \\
\text { RM1 Water } \\
\text { CROW Water } \\
\text { Tank Bottom Water } \\
\text { Sludgy Water } \\
\text { Treolite Distillates } \\
\text { Free \& Distilled Water }\end{array}$ & $\begin{array}{l}\text { Disposable Glass Coliwasa } \\
\text { Disposable Glass Coliwasa } \\
\text { Disposable Glass Coliwasa } \\
\text { Disposable Glass Coliwasa } \\
\text { Disposable Glass Coliwasa } \\
\text { Composite, Mix, \& Pour } \\
\text { Composite, Mix, \& Pour } \\
\text { Composite, Mix, \& Poura } \\
\text { Disposable Glass Coliwasa } \\
\text { Disposable Glass Coliwasa } \\
\text { Disposable Glass Coliwasa } \\
\text { Disposable Glass Coliwasa } \\
\text { Drain from Drum Valve }\end{array}$ \\
\hline $\begin{array}{l}\text { Tars, Oils, and } \\
\text { Hydrocarbon Liquids }\end{array}$ & $\begin{array}{l}\text { Tank Bottom Heavy } \\
\text { Oil Solid } \\
\text { Oil Pitch } \\
\text { Shale Oil-1 } \\
\text { Shale Oil-2 } \\
\text { Shale Oil-9 } \\
\text { Shale Oil Distillates } \\
\text { Tar Sand Heavy Oil }\end{array}$ & $\begin{array}{l}\text { Disposable Scoop } \\
\text { Gloved Hand as Scoop } \\
\text { (very hard material) } \\
\text { Disposable Glass Coliwasa } \\
\text { Disposable Glass Coliwasa } \\
\text { Disposable Glass Coliwasa } \\
\text { Disposable Glass Coliwasa } \\
\text { Sludgy Samples- } \\
\text { Disposable Scoop } \\
\text { Liquid Samples- } \\
\text { Teflon Coliwasa } \\
\text { Disposable Scoop } \\
\text { Teflon Coliwasa } \\
\text { Sludey Samples- } \\
\text { Disposable Scoop } \\
\text { Liquid Samples- } \\
\text { Disposable Glass } \\
\text { Coliwasa } \\
\text { Sticky Samples- } \\
\text { Disposable Scoop } \\
\text { Viscous Samples- } \\
\text { Teflon Coliwasa } \\
\text { Disposable Glass Coliwasa }\end{array}$ \\
\hline
\end{tabular}

- There are only small quantities of these, and they were contained in several small containers. 
Table 11. Sampling Equipment Used in Phace I of the North Site Cleanup Project (continued)

\begin{tabular}{|c|c|c|}
\hline Product Stream & Sample & Sampling Equipment \\
\hline $\begin{array}{l}\text { Tars, Oils, and } \\
\text { Hydrocarbon Liquids } \\
\text { (continued) }\end{array}$ & $\begin{array}{l}\text { Tank Water } \\
\text { Tank Oil } \\
\text { Distillate Light Oil } \\
\text { Tank Cleanout } \\
\text { Tank Cleanout Oil } \\
\text { Oily Material Plus } \\
\text { Water }\end{array}$ & $\begin{array}{l}\text { Sticky Samples - Large } \\
\text { Scoop } \\
\text { Viscous Samples- } \\
\text { Teflon Coliwasa } \\
\text { Sludgy Samples- } \\
\text { Disposable Scoop } \\
\text { Liquid Samples- } \\
\text { Disposable Glass } \\
\text { Coliwasa } \\
\text { Drain from Spigot } \\
\text { Stainless Steol Tube } \\
\text { Pour from Drum Spigot } \\
\text { Disposable Glass Coliwasa } \\
\text { Long-Handled Scoop } \\
\text { Solid Samr les- } \\
\text { Long-Handled Scoop } \\
\text { Liquid Samples- } \\
\text { Disposable Gless } \\
\text { Coliwasa } \\
\text { Disposable Scoop }\end{array}$ \\
\hline Unknown Materials & $\begin{array}{l}\text { Pellets } \\
\text { Untenown Liquid } \\
\text { Untnown Material } \\
\text { SAI Comp Material-Liquid } \\
\text { SAI Comp Material-Solid } \\
\text { Artic 75/90 }\end{array}$ & $\begin{array}{l}\text { Disposable Scoop } \\
\text { Disposable Glass Coliwasa } \\
\text { Disposable Glass Coliwasa } \\
\text { Dispcsable Glass Coliwasa } \\
\text { Disposable Scoop } \\
\text { Disposable Glass Coliwasa }\end{array}$ \\
\hline Chemicals & $\begin{array}{l}\text { Monoethanolamine } \\
\text { Tretolite } \\
\text { Caustic Soda } \\
\text { Boiler Water Treatment } \\
\text { Dry Water Treatment-1 } \\
\text { Dry Water Treatment-2 } \\
\text { Soda Ash }\end{array}$ & $\begin{array}{l}\text { Disposable Glass Coliwasa } \\
\text { Disposable Glass Coliwasa } \\
\text { Disposable Glass Coliwasa } \\
\text { Disposable Glass Coliwasa } \\
\text { Disposable Scoop } \\
\text { Pour from Container } \\
\text { Disposable Scoop }\end{array}$ \\
\hline
\end{tabular}




\section{Sempling QARQC}

To prevent cross contamination from one sample to the next, disposable sampling equipment (e.g., disposable glass coliwasas and disposable scoops) was used whenever possible. Sample equipment which was reused was thoroughly cleaned between uses. The following procedure was used to wash sampling equipment prior to reuse.

1. Wash with soapy water

2. Rinse with type II water

3. Rinse with $10 \%$ nitric acid

4. Rinse with typa II water

5. Repeat steps 3 and 4 three times

6. Rinse with methanol or other appropriate solvent and dry

Sample storage containers were I-Chem Series 200 precleaned bottles, which are cleaned to meet U.S. Environmental Protection Agency (EPA) specifications. Samples for metals analysis were placed in I-Chem precleaned polyethylene containers; samples for analysis of semivolatile organic compounds were added to IChem precleaned glass containers; and samples for analysis of volatile organic compounds were placed in I-Chem precleaned vials having Teflon-lined septum caps. Samples requiring compositing prior to metals analysis were added to I-Chem precleaned polyethylene containers, and samples requiring compositing prior to organic analyses were added to I-Chem precleaned glass containers. The only exception to the activities described above is that because of the difficulty in sampling and collecting the oils, tare, and hydrocarbon liquids during the winter, many times a single I-Chem glass container of the material was collected. Samples for Toxicity Characteristic Leaching Procedure (TCLP) extraction were also placed

$\therefore$ I-Chem precleaned glass containers. The composition of the sampling equipment ind sample containers was selected to minimize loss of analytes due to adsorption or contamination caused by leaching. Precautions were also taken during sampling to prevent loss of volatile components from the samples.

An indelible label identifying the sample was filled out and secured to each sample container at the time of sampling. Each sample label contained the following information:

- Date and time of sampling (month/day/yr;time)

: Location of sampling (area)

- Description of sample

- Sample identification number (This includes material inveritory seria) number, WRI sampling logbook number, and sampling logbook page number where the information on the eample can be found.)

- Name of sample collector

- Type of preservation, if any

- Analytical requirements (i.e., TCLP, BNA, VOC, Metals)

Chain-of-custody procedures were used to ensure the integrity of the samples from collection to data reporting. This was accomplished by creating a paper trail 
that identified the specific individuals responsible for the custody of a given sample at any point in time. The component of chain-of-custody, sample seals, a field (sampling) logbook, a chain-of-custody record, and a sample analysis request sheet, were used to document the history of each sample. Once a sample container was filled, a chain-of-custody seal was attached to the container in a manner such that the sample container could not be opened without breaking the seal. Each chain-ofcustody seal contained the following information:

- Sample number (This was identical to the number on the sample label.)

- Name of collector

- Date and time of sampling

All information pertinent to sampling was recorded in a logbook. Sample documentation in the sample logbook was initiated at the time a sample was taken and includes the following:

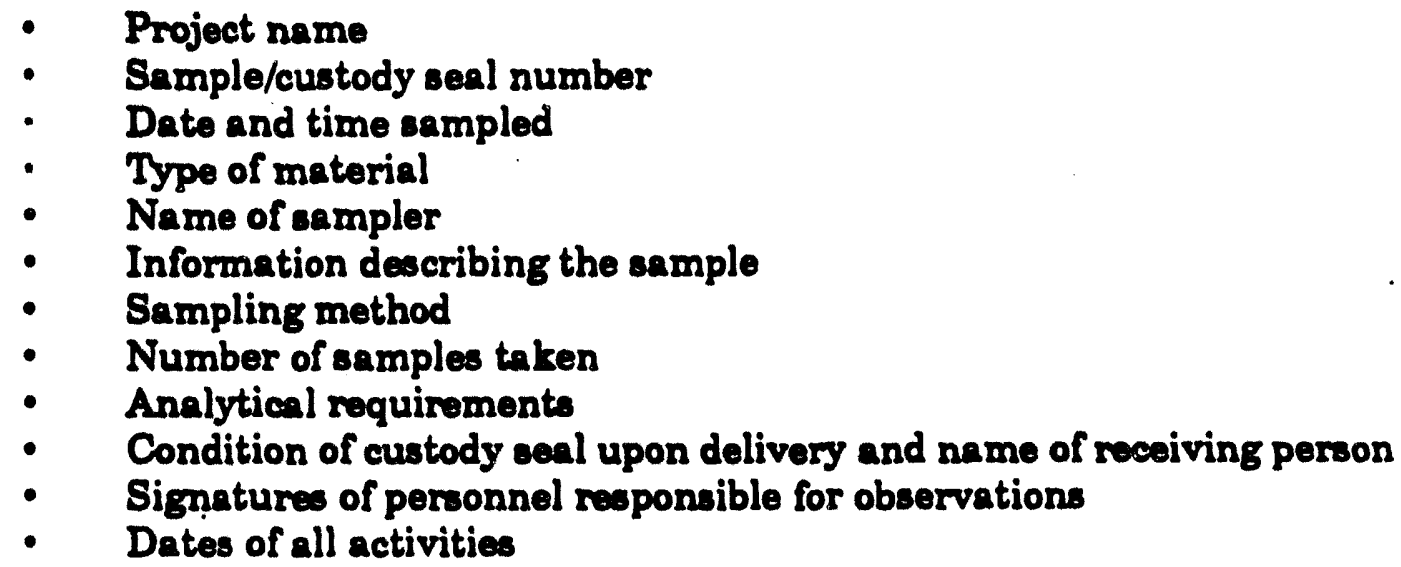

When not in use, the sample logbook is securely and safely stored. All information is recorded in the sample logbook using ink.

To establish the documentation necessary to trace sample possession from the time of collection, a chain-of-custody record was filled out and accompanied the samples. The chain-of-custody record is a triplicate form. The original and yellow sheets accompanied the samples to the analytical laboratory; and the pink shoet was retained by the sampling personnel and placed in a permanent project file. The yellow sheet was returned by the laboratory personnel to the document coordinator to verify sample receipt, and the original was returned by the laboratory personnel with the remaining samples after analyses were completed. The chain-of-custody record contains the following information:

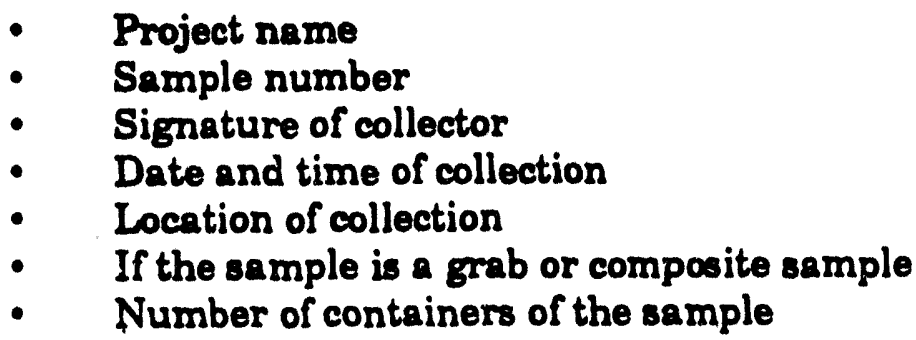


- Signature of persons involved in the chain-of-possession

- Inclusive dates of possession

For samples requiring compositing after they were collected, two chain-ofcustody records were prepared. One was prepared in the field by the sample collector and lists the samples that were collected at the North Site. A second chain. of-custody record was prepared when samples were composited in the laboratory to give a single sample for analysis. The pink sheet of the sacond form and original and yellow sheets of the first form document sample compositing for chain-of. custody purposes and were placed in the permanent project file. The original and yellow sheets of the second form were sent to the laboratory personnel and handled as described above.

A sample analysis request sheet was also sent with the samples to the laboratory. This lists the samples for analysis, sample description and source, and the analysis requested. A chain-of-custody form and sample analysis request form accompanied all samples to WRI's laboratory and to the outside laboratories. Copies of the chain-of-custody records and sample analysis request forms for the samples involved in phase I of this project are provided in Appendix C.

After the samples were collected, they were stored in a locked, refrigerated storage area until being extracted, analyzed, or shipped for analysis. Storage time was limited to meet analytical holding times.

Field trip blanks were prepared for the sampling activities. Each set of trip blanks consisted of deionized, distilled water added to the appropriate precleaned I. Chem container for metals, semivolatile organic, and volatile organic analyses. The trip blanks were taken to the North Site sampling areas by the sampling team. They were exposed to the same sampling and storage conditions as the actual samples and accompanied the samples to the laboratory for analysis. Analysis of the trip blanks verifies that none of the analytes of interest measured in the samples result from contamination of the samples in the field or during storage.

During the course of sampling, five sets of trip blanks were prepared and taken to the North Site. One set was for sampling some of the North Site water composite groups; one set was for sampling some of the tars, oils, and hydrocarbon liquids composite groups; a third set was for sampling materials requiring TCLP extraction; a fourth set was taken to the field for sampling the North Site chemical stream; and a fifth set of trip blants was for sampling the oil pitch composite group for TCLP extraction. Table 12 lists the trip blank numbers and the corresponding composite groups that were sampled.

In addition to field trip blanks, two sets of field equipment blanks were also prepared. Glass coliwasa and plastic scoop equipment blanks were to show any contamination of the samples contributed by these sampling devices. The equipment blanks consisted of deionized, distilled water poured appropriately over or through the sample collection device, collected in an appropriate sample container for analysis of metals, semivolatile organic compounds, and volatile organic compounds, and submitted blind to the laboratory for analysis. 
Table 12. North Site Sampling Field Trip Blanks and Composite Groups Sampled

Field Trip Blanks

Set 1

Set 2

Set 3

Set 4

Set 5
Composite Groups Sampled

Graham W: ter

Tank Bottom Water

Retort Water

Sludey Water

Tank Cleanout Water

Water Scavenger

Treolite Distillate

Free \& Distilled Water

Tank Bottom Heavy Oils

Tank Water.

Tank Bottom

Heavy Oil Plus Coal

Tar Sand Heavy Oil

Coal Tars

Heavy Oils

Heavy Fuel Oils

Shale Oil Distillates

Crushed KC Rock

Rew Eastern Oil Shale

Raw Oil Shale Pile

Tank Bottom Heavy Oil Solid

Pellets

Monoethanolamine

Tretolite

Caustic Soda

Boiler Water Treatment

Soda Ash

Dry Water Treatment-1

Dry Water Treatment-2

Oil Pitch 
Preparation of Composite Samples for Analysis

\section{Composite Samples}

To reduce analytical costs, many samples of the North Site materials were composited prior to analysis. Composite samples were prepared by mixing samples of materials in the composite groups listed in Table 1. As previously mentioned, the composite groups contain materials known to be similar in composition, source, and process exposure. Table 13 shows the composite samples that were prepared for each product stream and the serial numbers of the materials that were mixed to prepare them.

Table 13. Composite Samples Prepared for Analysis in Phase I of the North Site Cleanup Project

\begin{tabular}{|c|c|c|}
\hline Product Stream & Composite Sample & Materials in Composite Sample \\
\hline $\begin{array}{l}\text { Unprocessed } \\
\text { Tar Sands }\end{array}$ & Tar Sand & $19,28,45,51,57,65,235,1159$ \\
\hline \multirow[t]{2}{*}{$\begin{array}{l}\text { Unprocessed } \\
\text { Coals }\end{array}$} & $\begin{array}{l}\text { Unprocessed } \\
\text { Western Coal }\end{array}$ & $83,213,217,372,1163$ \\
\hline & $\begin{array}{l}\text { Unprocessed } \\
\text { Eastern Coal }\end{array}$ & $2,115,810$ \\
\hline \multirow[t]{3}{*}{ Raw Oil Shales } & $\begin{array}{l}\text { Raw Western } \\
\text { Oil Shale }\end{array}$ & $139,247,395,460$ \\
\hline & $\begin{array}{l}\text { Raw Eastern } \\
\text { Oil Shale }\end{array}$ & $196,200,358,1167$ \\
\hline & Raw Shale Pile & $1260,1262-1264$ \\
\hline \multirow{6}{*}{$\begin{array}{l}\text { Spent Oil Shale, } \\
\text { Processed Tar } \\
\text { Sand, Activated } \\
\text { Charcoal }\end{array}$} & Spent Oil Shale-1 & $330,367,541,546,818$ \\
\hline & Spent Oil Shale-2 & 1080,1081 \\
\hline & Spent Oil Shale Pile & 1259,1261 \\
\hline & Spent Tar Sand & 370,373 \\
\hline & Activated Charcoal & $\begin{array}{l}684,690,700,826,830 \\
835,840,845,850,1170\end{array}$ \\
\hline & MG Fines, Char & $1204,1205,1217,1223,1257$ \\
\hline
\end{tabular}


Table 13. Composite Samples Prepared for Analysis in Phase I of the North Site Cleanup Project (continued)

\begin{tabular}{|c|c|c|}
\hline Product Stream & Composite Sample & Materials in Composite Sample \\
\hline \multirow{4}{*}{$\begin{array}{l}\text { Miscellaneous } \\
\text { Materials }\end{array}$} & Tank Bottom Liner & 820,823 \\
\hline & $\begin{array}{l}\text { Evaporation Tank } \\
\text { Bottom Dirt }\end{array}$ & 1244,1245 \\
\hline & Oily Dirt & $645,655,999$ \\
\hline & Fly Ash & $891-912$ \\
\hline \multirow[t]{5}{*}{ Waters } & Retort Water & $350,1079,1122$ \\
\hline & Graham Water & 1113,1120 \\
\hline & $\begin{array}{l}\text { Tank Cleanout } \\
\text { Water }\end{array}$ & 931,944 \\
\hline & CROW Water & 1267,1268 \\
\hline & Tank Bottom Water & $824,889,947$ \\
\hline \multirow{9}{*}{$\begin{array}{l}\text { Tars, Oils, \& } \\
\text { Hydrocarbon } \\
\text { Liquids }\end{array}$} & $\begin{array}{l}\text { Tank Bottom Heavy } \\
\text { Oil }\end{array}$ & $627,888,929$ \\
\hline & $\begin{array}{l}\text { Tank Bottom Heavy } \\
\text { Oil Solid }\end{array}$ & $55,643,890$ \\
\hline & Oil Pitch & $953,975,976,1258$ \\
\hline & Shale Oil-1 & $279,282,293,298,301,319,322$ \\
\hline & Shale Oil-2 & 344,346 \\
\hline & Shale Oil-3 & $776,777,779,781,783$ \\
\hline & $\begin{array}{l}\text { Shale Oil } \\
\text { Distillates }\end{array}$ & $614,615,656$ \\
\hline & $\begin{array}{l}\text { Tar Sand Heavy } \\
\text { Oil-1 (liquid) }\end{array}$ & $599,1141,498$ \\
\hline & $\begin{array}{l}\text { Tar Sand Heavy } \\
\text { Oil-2 (mucky solid) }\end{array}$ & $64,1139,577$ \\
\hline
\end{tabular}


Table 13. Composite Samples Prepared for Analysis in Phase I of the North Site Cleanup Project (continued)

\begin{tabular}{|c|c|c|}
\hline Product Stream & Composite Sample . & Materials in Composite Sample \\
\hline \multirow{13}{*}{$\begin{array}{l}\text { Tars, Oils, \& } \\
\text { Hydrocerbon } \\
\text { Liquids (continued) }\end{array}$} & $\begin{array}{l}\text { Heavy Oil Plus } \\
\text { Coal-1 (mucky solid) }\end{array}$ & 474,476 \\
\hline & $\begin{array}{l}\text { Heavy Oil Plus } \\
\text { Coal-2 (mucky solid) }\end{array}$ & 500,502 \\
\hline & Dirty Oil \& Sludge & $785,795,858$ \\
\hline & Coal Tar-1 (liquid) & $\begin{array}{l}482,959,961,963,965,967 \\
969,973\end{array}$ \\
\hline & $\begin{array}{l}\text { Coal Tar-2 (mucky } \\
\text { solid) }\end{array}$ & $\begin{array}{l}482,959,961,963,965,967 \\
969,973\end{array}$ \\
\hline & Coal Tar-3 & $1135-1138$ \\
\hline & Heavy Fuel Oil & $6,7,9,10,11,12$ \\
\hline & Heavy Crude Oil & $787,792,793$ \\
\hline & $\begin{array}{l}\text { Tank Bottom-1 } \\
\text { (liquid) }\end{array}$ & 978,957 \\
\hline & $\begin{array}{l}\text { Tank Bottom-2 } \\
\text { (mucky solid) }\end{array}$ & 958,943 \\
\hline & $\begin{array}{l}\text { Distillate } \\
\text { Light Oil }\end{array}$ & 1199,1200 \\
\hline & $\begin{array}{l}\text { Oily Material } \\
\text { Plus Water-1 (liquid) }\end{array}$ & $604,606,609$ \\
\hline & $\begin{array}{l}\text { Oily Material } \\
\text { Plus Water-2 (hard solid) }\end{array}$ & 600,602 \\
\hline \multirow[t]{2}{*}{ Unknown Materials } & Pellets & $518,519,520$ \\
\hline & Unknown Material & 992,993 \\
\hline Chemicals & Tretolite & 352,617 \\
\hline
\end{tabular}




\section{Compositing Procedures}

Composite samples were prepared in the laboratory with care to prevent lose of volatile constituents from the samples. Beceuse all of the samples were refrigerated during storage, the materials were cold at the time of compositing, which helped provent lose of volatile maturials.

Materials in the unprocessed tar sand, unprocessed coal, raw oil shale, spent oil shale, processed tar sand, activated charcoal, and miscellaneous material streams that required compositing are all solids, as are the tank bottom heavy oil solid and oil pitch in the tar, oil, and hydrocarbon liquid stream and the pellets in the unknown material stream (Table 13). All of these materials were to be extracted by TCLP, which requires a particle size of $9.5 \mathrm{~mm}$ or less. The cold samples having a particle size greater than $9.5 \mathrm{~mm}$ were placed between shoets of Teflon-lined paper and crushed to reduce their particle size prior to compositing. One exception was the tank bottom liner, which consists of reinforced, rubber-like sheets. This material required cutting with sciesors. Also, the pellets can be broken into smaller warticles using a spatula. Solids requiring particle size reduction by crushing were $\therefore$..ee of the tar sand materials, the western and eastern raw oil shales, materials rom the oil shele pile, and the oil pitch. For the materials requiring particle size reduction, the entire sample was reduced prior to compositing. To prepare the solid composite samples, equal masses of material were added to a large, cold, glass container. The container was sealed, and the material was thoroughly mixed. The mass of each solid material used to prepare a composite sample ranged from approximately 100 to $700 \mathrm{~g}$. After mixing, the composite sample was added to an IChem precleaned glass container and submitted to WRI's laboratory for TCLP extraction.

Water samples for compositing were collected in l-liter I-Chem polyethylene containers for metals analysis and in 1-liter I-Chem glass containers for semivolatile and volatile organic analyses. Water composite samples were prepared by mixing equal volumes of the waters from the polyethylene bottles $(\sim 800 \mathrm{~mL})$ in a large, sealed, polyethylene container to give a composite for metals analysis, and by mixing equal volumes of the waters from the glass bottles $(-800 \mathrm{~mL})$ in a cold, sealed, glass container (i.e., volumetric/Erlenmeyer flask) to give a composite for organic analyses. After mixing, the composite for metals analysis was divided between two 1-liter I-Chem polyethylene bottles, one for analysis by WRI and one for analysis by a second laboratory. After the organic composite was prepared, it was divided between two 1-liter I-Chem glass bottles and four $40-\mathrm{mL}$ I-Chem vials for semivolatile organic and volatile organic analysis, respectively. One 1-liter container and two of the $40-\mathrm{mL}$ vials were submitted to WRI, and the other three containers were for analysis by an outside laboratory. 
Oils, tars, and hydrocarbon liquid samples were to be collected in I-Chem polyethylene containers for metals analysis and in I-Chem glass containers for organic analysis. However, because of the difficulty in sampling and collecting these types of materials during the winter, many times a single I-Chem glass container of the material was provided for compositing. Oily liquid composite samples were prepared by mixing equal volumes of the liquids (generally 150 to $250 \mathrm{~mL}$ ) in a cold, sealed, glass container, such as a volumetric or Erlenmeyer flask, and dividing the composite sample between appropriate sample containere for metals and organic analysos. Solid composite samples were propared by mixing equal masses of the materials (generally $10.30 \mathrm{~g}$ for sticky solids, which were extremely difficult to remove from the sample container, and $150 \mathrm{~g}$ for mucky solids) in a cold, sealed, glass beaker and dividing the composite sample between appropriat sample containers for metals and oryanic analyses.

The oily material plus water composite sample was divided into two samples because materials 600 and 602 (soe Table 13) required heating to remove them from their sample containers. As shown in Table 13, multiple composite samples were aiso prepared for some of the other composite groups in the tar, oil, and hydrocarbon iquid stream. This was due to the difficulty in sampling these materials, causing them to be sampled at different times, and because some of the materials that were to be mixed were solids and liquids.

There are three coal tar composite samples listed in Table 13 because solid and liquid phases of the coal tar materials were separated (for analytical purposes) to give two composite samples, and materials 1135-1138 were sampled at a later time to give a third composite. There are also two composites for the heavy oil plus coal composite sample because sampling was performed at different times. Three shale oil sample composites were prepared because of the large number of shale oil materials.

The unknown material composite sample listed in Table 13 under the unknown material stream was prepared by mixing $1000 \mathrm{~mL}$ of each material in a cold, 2-liter, capped volumetric nesk. The composite sample was divided between a 1-liter I-Chem glass container for semivolatile organic analysis, a 1-liter I-Chem polyethylene bottle for metals analysis, and two I-Chem vials for volatile organic analysis. Analyses of this composite sample were performed by WRI only.

The tretolite composite sample listed in Table 13 under the chemical stream was prepared by mixing $1,500 \mathrm{~mL}$ of each material in a cold, $4000-\mathrm{mL}$, sealed Erlenmeyer flask. The composite sample was then divided between the appropriate sample containers and submitted for analyses by WRI. 
In proparing the composite samples, contents of the sample containers, which had been refrigerated, were well mixed prior to removing material for the composite. This was done in a manner to prevent loss of volatile constituents. An exception to this was for the oily matorial plus water samples, 600 and 602 , which as mentioned above required heating to remove the materials from thoir sample containers. This activity was noted for roforence in evaluating data from analysis of the resulting composite aumple. After the materials comprising a composite sample were added to the compositing container, they were thoroughly mixed. Sufficient mixing was performud to onsurn that atratification did not occur and to give as homogeneous a sample as possible. For liquid matrices, the materials were swirled or shaken in cold, sealed containers to mix them and prevent loss of volatile organic constituents. For solid and semi-solid materials, mixing was accomplished by stirring the materials in cold, sealed containers, with care to prevent loss of volatile compounds. Compositing containers and any utensils used in preparing the composites were thoroughly cleaned between preparation of composite samples to prevent cross contamination. Information concerning preparation of composite samples is irsorded in a WRI projoct notebook, which references the sample logbook and page r:umber where specific sample collection is described. Copies of WRI notebook pages providing information on sample compositing are included in Appendix B.

\section{Analveis of North Site Samplea}

Materials stored at the North Site were analyzed for their hazard classification using the Resource Conservation and Recovery Act (RCRA) (1984) definition for wastes. Some of these materials will be furthor identified as not being needed for additional research and may be reclassified as wastes depending on their potential for industrial use. RCRA controls disposal of wastes (liquids, solids, semisolids, and containerized gases), and requires that wastes destined for land disposal be evaluated for their potontial hazard to the environment. Wastes are divided into two classifications, nonhazardous and hazardous. Hazardous wastes are defined by the EPA (40 CFR 261, Subpart C, 1992) as wastes that demonstrate the characteristic of ignitability, corrosivity, reactivity, or toxicity, and they also include wastes listed in 40 CFR 261, Subpart D (listed wastes) (1992).

\section{Analytical Approach}

The analytical approach to this project is shown in Figure 1 and summarized in Table 14. Each material type was evaluated for exemption as a hazardous waste under 40 CFR 261, Subpart A (1992). Materials falling into one of the categories for an exempt waste are nonhazardous. If a North Site material was not exempt, it was evaluated based on being listed under 40 CFR 261, Subpart D (1992). Any listed waste is hazardous and requires no sampling or analyses. Materials that were not listed wastes were then evaluated for the hazard characteristic they were most likely to exhibit. The composite samples and individual samples for each product stream that required analysis in phase I are listed in Table 15. 


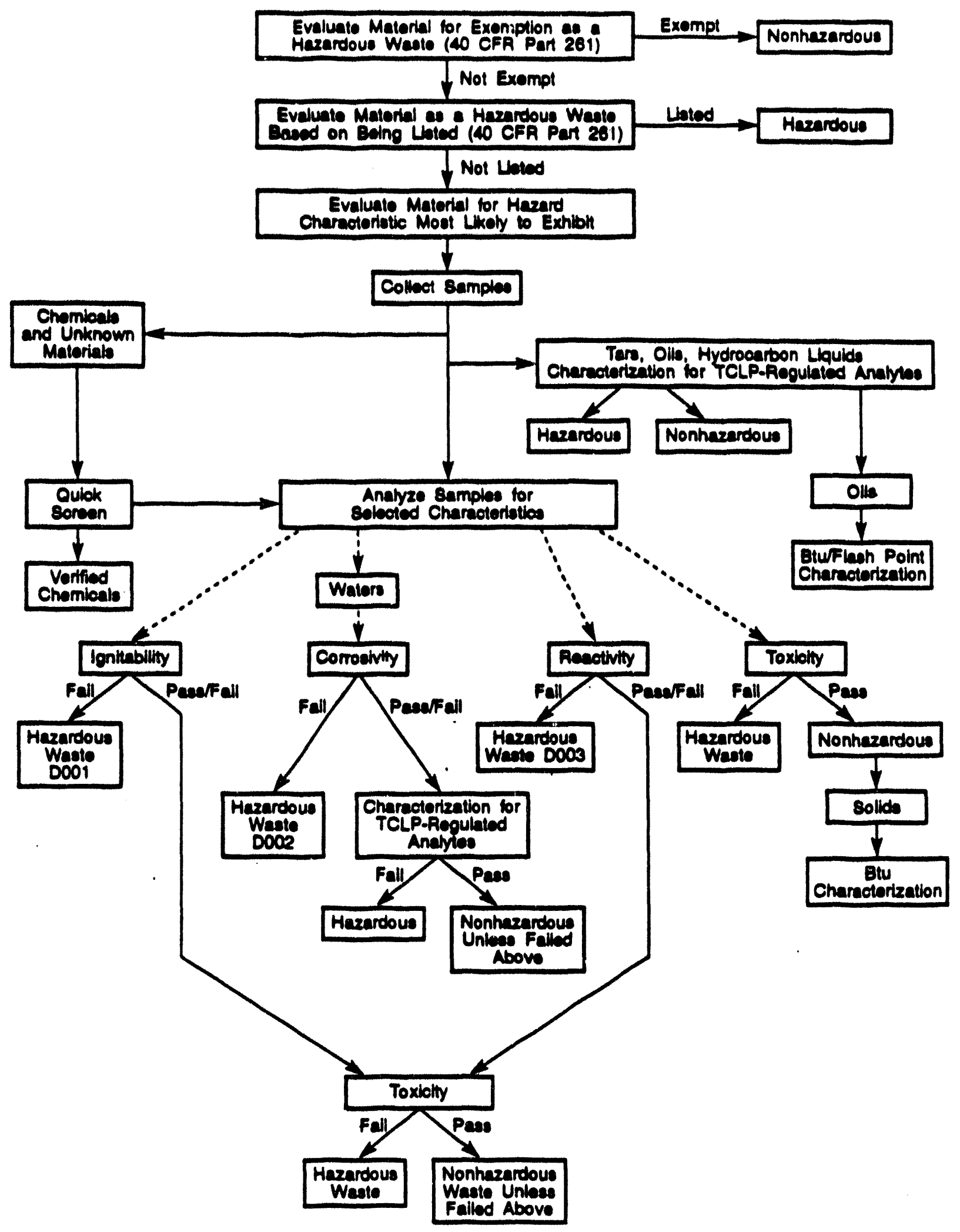

Figure 1. North Site Material Characterization 
Table 14. North Site Sample Characterization

Product Stroam

Unknown Matoriale
Rocommended Analyois

Quick scroon

EPA Methode 3580,8000

EPA Mothods 3010/3050 \&

6010

EPA Mothod 300.2

Evaluate hazard

charactoriatic:

Total characterization

for TCLP regulatod analytes

Chemicals

Tars, Oils, and

Hydrocarbon Liquids

Some Oils

Distillates
Quick scroen

EPA Methods 3580,8000

EPA Mothods 3010/3050 \& 6010

EPA Mothod 900.2

Evaluate hazard

characteristic:

Total characterization

for TCLP regulatod analytes

Evaluate hazard characteristic: Total characterization for TCLP regulatod analytos

Btu analysis-ASTM D-240

Evaluate hazerd characteristic:

Flash Point-ASTM D.93
Rationale

Information on composition/ identity

Classify as hazardous or nonhazardous

Information on composition/ identity

Classify as hazardous or nonhazardous

Classify as hazardous or nonhazardous

Evaluate use as fuel

Classify as hazardous or nonhazardous 
Table 14. North Site Sample Charactorizatton (continued)

Product Stroam

Recommended Analyeis

Rationale

Unproceased Tar Sands

Unprocesesed Cosls

Raw Oil Shales

Spent Tar Sands

Spent Oil Shales

Activated Chareoal

Miscollanoous Matorials

Evaluate hazand

charactoriatic:

Toxicity-EPA Method 1311

Classify as

hazardous or

nonhazardous

Unprocessed Tar Sands

Unprocessed Coals

Raw Oil Shales

passing TCLP

Btu analyois-ASTM D-2015

Determine heat

capacity for

disposal

Waters

Evaluate hazard

charactoristic:

Corrosivity-EPA Mathod 9040

or Reactivity-EPA 7.8.3.2

7.3.4.2 (SW-846, U.S. EPA

1986)

Evaluate hazard

characteristic:

Total characterization

for TCLP regulated analytes

Classify as

hazerdous or

nonhazardous

Classify as

hezardous or

nonhazardous 
Table 16. Compoalte Samples and Individual Samplee Requiring Analyeis in Phave I of the North Bite Cleanup Project

Product Btream

Componito Sample

Individual Sample

Unproceessed

Tar Sands

Tar Sand

Tar Sand Sludge

Unprocessed

Unprocessed

Coals

Westorn Coal

Unprocesesed

Eastorn Coal

Raw Oil Shales

Raw Weatorn

Oil Shale

Raw Eastorn

Oil Shale

Raw Shalo Pile

Spont Oil Shale, Procesesed Tar

Sand, Activated

Charcoal

Spent Oil Shalo-1

Spont Oil Shalo-2

Spont Oil Shale Pile

Spont Tar Sand

Activated Charcoal

MG Fines, Char

Miscellaneous

Materials

Tank Bottom Liner

Evaporation Tank

Bottom Dirt

Oily Dirt

Unused Activated

Chareoal

Fly Ash

Waters

Rotort Wator

Graham Water

Tank Cleanout

Wator

Tank Bottom Wator

CROW Water

Wator Souvonger

Wator, Coal Fines,

Oil

Unidentifiod UCG Water

Hoo Creok Wator

RM1 Water

Sludgy Wator

Treolite Distillates

Froe \& Diatilled Water 
Table 18. Composite Samples and Individual Samples Requiring Analysis in Phase I of the North Site Cleanup Project (continued)

\begin{tabular}{|c|c|c|}
\hline Product Stroam & Composite Sample & Individual Sample \\
\hline $\begin{array}{l}\text { Tare, Oils, } \\
\text { Hydrocarbon Liquids }\end{array}$ & $\begin{array}{l}\text { Tank Bottom Heavy } \\
\text { Oil Solid } \\
\text { Oil Pitch } \\
\text { Shale Oil-1 } \\
\text { Shale Oil-2 } \\
\text { Shale Oil-s } \\
\text { Shale Oil Distillates } \\
\text { Tar Sand Heavy Oil } \\
\text { Heavy Oil Plus Coal } \\
\text { Dirty Oil \& Sludge } \\
\text { Coal Tar } \\
\text { Heavy Oil } \\
\text { Heavy Fuel Oil } \\
\text { Heavy Crude Oil } \\
\text { Tank Bottom } \\
\text { Distillate Light Oil } \\
\text { Oily Material Plus Water } \\
\text { Tank Bottom Heavy Oil }\end{array}$ & $\begin{array}{l}\text { Tank Water } \\
\text { Tank Oil } \\
\text { Tank Cleanout } \\
\text { Tank Cleanout Oil } \\
\end{array}$ \\
\hline Unknown Mntorialo & $\begin{array}{l}\text { Pollots } \\
\text { Untenown Material }\end{array}$ & $\begin{array}{l}\text { Untonown Liquid } \\
\text { SAI Comp Material-Liquid } \\
\text { SAI Comp Material-Solid } \\
\text { Artic 75/90 }\end{array}$ \\
\hline Chemicals & Tretolite & $\begin{array}{l}\text { Monoethanolamine } \\
\text { Caustic Soda } \\
\text { Boiler Water } \\
\text { Treatment } \\
\text { Dry Water Treatment-1 } \\
\text { Dry Water Treatment-2 } \\
\text { Soda Ash }\end{array}$ \\
\hline
\end{tabular}




\section{Analyais of Unknown Materials and Chemicals}

The unknown materials and chemicals were analyzed using quick screening methods to provide information on their composition and identity. EPA Method 3580 for waste dilution (U.S. EPA 1986) was used to prepare the untenown materials and chemicals for organic analysis by gas chromatography using EPA Method 8000 (U.S. EPA 1986). EPA Method 3010 or 3050 (U.S. EPA 1986) was used to digest the materials for metals analysis, and EPA Mothod 6010 (U.S. EPA 1986) was used to analyze the digestates. Some of these materials were also screened for anions using EPA Method 800.2 (U.S. EPA 1989). Materials that were not positively identified or determined to be hazardous were analyzed for their concentrations of the toxicity characteristic regulated analytes (U.S. EPA 1990). These analytes and the analytical methods required for their measurement are listed in Table 16 (U.S. EPA 1990). EPA Method 1311, the Toxjcity Cherecteristic Leaching Procedure (TCLP) (U.S. EPA 1990) is most often used to determine toxicity. However, for cost and time effectiveness, it was decided to measure the levels of the regulated analytes in these materials, rather than perform both TCLP extraction and analysis.

\section{Analysis of Tars, Oils, and Hydrocarbon Liquids}

Tars, oils, and hydrocarbon liquids were to be analyzed by a total characterization to determine the levels of the toxicity characteristic regulated analytes present in these materials. As mentioned above, these analytes are listed in Table 16 and are used to evaluate the characteristic of toxicity. The TCLP is most often used to determine toxicity; however, there are many difficulties encountered when trying to apply this procedure to oily-type materials. The method is not designed for applicability to these types of materials. The TCLP states that if a total analysis of the material demonstrates that individual contaminants are not present, or that they are present, but in such low concentrations that the appropriate regulatory thresholds could not possibly be exceeded, the TCLP need not be run. This approach was to be taken for the tars, oils, and hydrocarbon liquids using the methods listed in Table 16 for the specific analytes. Any of these materials not meeting one of the criteria given above would be considered hazardous. However, difficulties were encountered in analyzing some of these materials. Because the tars and oils require high levels of dilution for total characterization of the TCLP regulated analytes, the method detection limits for the first set of samples analyzed were found to be higher than the TCLP regulatory levels. To handle this problem, the following approach was used. Samples from this product stream were analyzed first for regulated TCLP volatile compounds, specifically benzene, using the procedure described below. Those samples for which the procedure did not give TCLP volatile compounds greater than the action limits were then analyzed for their cresol content using SW-846 gas chromatography/mass spectrometry (GC/MS) methods. Gel permeation chromatography, SW-846 Method 3640 (U.S. EPA 1986), was used to cleanup the samples by removing high molecular weight compounds before GC/MS analysis. 
Table 16. Toxiclty Characteristic Constituents", Regulatory Levels, Analytical Method Numbers, and Hezandous Waste Numbers

\begin{tabular}{|c|c|c|c|}
\hline EPA HW No.b & Constituent & $\begin{array}{c}\text { Regulatory Lovel, } \\
m \& /\end{array}$ & $\begin{array}{c}\text { SW-846 } \\
\text { Method No. }\end{array}$ \\
\hline $\begin{array}{l}\text { D004 } \\
\text { D005 } \\
\text { D018 } \\
\text { D006 } \\
\text { D019 } \\
\text { D021 } \\
\text { D022 } \\
\text { D007 } \\
\text { D023 } \\
\text { D024 } \\
\text { D025 } \\
\text { D026 } \\
\text { D027 } \\
\text { D028 } \\
\text { D029 } \\
\text { D030 } \\
\text { D032 } \\
\text { D033 } \\
\text { D034 } \\
\text { D008 } \\
\text { D009 } \\
\text { D035 } \\
\text { D036 } \\
\text { D037 } \\
\text { D038 } \\
\text { D010 } \\
\text { D011 } \\
\text { D039 } \\
\text { D040 } \\
\text { D041 } \\
\text { D042 } \\
\text { D043 }\end{array}$ & $\begin{array}{l}\text { Arsenic } \\
\text { Barium } \\
\text { Benzene } \\
\text { Cadmium } \\
\text { Carbon Tetrachloride } \\
\text { Chlorobenzene } \\
\text { Chloroform } \\
\text { Chromium } \\
\text { o-Cresol } \\
\text { m-Cresol } \\
\text { p-Cresol } \\
\text { Cresol } \\
\text { 1,4-Dichlorobenzene } \\
\text { 1,2-Dichloroethane } \\
\text { 1,1-Dichloroehtylene } \\
\text { 2,4-Dinitrotoluene } \\
\text { Hexachlorobenzene } \\
\text { Hexachloro-1,3,butadiene } \\
\text { Hexachloroethane } \\
\text { Lead } \\
\text { Mercury } \\
\text { Methyl ethyl ketone } \\
\text { Nitrobenzene } \\
\text { Pentachlorophenol } \\
\text { Pyridine } \\
\text { Selenium } \\
\text { Silver } \\
\text { Tetrchloroethylene } \\
\text { Trichloroethene } \\
\text { 2,4,5-Trichlorophenol } \\
\text { 2,4,6-Trichlorophenol } \\
\text { Vinyl chloride }\end{array}$ & $\begin{array}{l}5.0 \\
100.0 \\
0.5 \\
1.0 \\
0.5 \\
100.0 \\
6.0 \\
5.0 \\
200.0^{\circ} \\
200.0^{\circ} \\
200.0^{\circ} \\
200.0^{\circ} \\
7.5 \\
0.5 \\
0.7 \\
0.13 \\
0.13 \\
0.5 \\
3.0 \\
5.0 \\
0.2 \\
200.0 \\
2.0 \\
100.0 \\
5.0 \\
1.0 \\
5.0 \\
0.7 \\
0.5 \\
400.0 \\
2.0 \\
0.2\end{array}$ & $\begin{array}{c}6010^{\circ} / 7060,7061^{d} \\
6010 / 7080,7081 \\
8020 / 8024 \\
6010 / 7130,7131 \\
8010,8240 \\
8020,8240 \\
8010,8240 \\
8010 / 7190,7191 \\
8040,8250 \\
8040,8250 \\
8040,8250 \\
8040,8250 \\
8010,8120 \\
8010,8240 \\
8010,8240 \\
8090,8250 \\
8090,8250 \\
8120,8250 \\
8010,8240 \\
6010 / 7420,7421 \\
-7470,7471 \\
8015,8240 \\
8090,8250 \\
8040,8250 \\
8090,8250 \\
6010 / 7740,7741 \\
6010 / 7760,7761 \\
8010,8240 \\
8010,8240 \\
8040,8250 \\
8040,8250 \\
8010,8240\end{array}$ \\
\hline
\end{tabular}

- Regulated pesticides and herbicides are not listed.

b EPA hazardous waste number

c Method in 3rd edition of SW-846

d Method in 2nd edition of SW-846

- If $0-, \mathrm{m}-$, and p-cresol concentrations can not be differentiated, the total cresol (D026) concentration is used. The regulatory level for total cresol is $200 \mathrm{mg} / \mathrm{L}$. 
Volatile Analysis of the Tars, Oils, and Hydrocarbon Liquids. These materials were treated as high-level samples. Extraction and analysis were ky EPA Method 8240 (U.S. EPA 1986). One gram of sample, instead of four grams, was used in the extraction procedure. $A 10 \mu \mathrm{l}$ aliquot of the extract was added to $5 \mathrm{~mL}$ of blank water, along with the internal standard. If results from this analysis did not show TCLP compounds greater than the action limits, a $100 \mu$ laliquot was analyzed.

Metals Analysis of the Tars, Oils, and Hydrocarbon Liquids. For metals determination, the samples were combusted prior to analysis using ASTM Method D-3684, Standard Test Method for Total Mercury in Coal by the Oxygen Bomb Combustion/Atomic Absorption Method (ASTM 1983). Following sample preparation, the combusted materials were analyzed by SW-846 Method 7470 for mercury, SW-846 Method 7060 for arsenic, and SW-846 Method 7740 for selenium (U.S. EPA 1986). EPA digestion Method 3050 and EPA Method 6010 were used to determine the concentrations of lead, cadmium, chromium, silver, and barium in the samples (U.S. EPA 1986).

Additional Characterization of the Tars, Oils, and Hydrocarbon Liquids. Some of the oils being stored at the North Site may be useful as fuels and were tested for their Btu (British thermal unit) content using ASTM Method D-240 (ASTM 1988), which is described in the Analytical Methods section of this report. Materials from the containers that were sampled for preparation and characterization of the heavy fuel oil composite were analyzed individually for their Btu content.

The three materials comprising the shale oil distillate composite and the distillate light oil composite were analyzed for their flash point using ASTM Method D-93, Standard Test Method for Flash Point by Pensky-Marten Closed Tester (ASTM 1988). This analysis was performed for ignitability testing.

\section{Characterization of the North Site Waters}

Waters were tested for $\mathrm{pH}$ (corrosivity) using EPA Method 9040 (U.S. EPA 1986). They were also analyzed for their total concentrations of the TCLP regulated analytes using the methods listed in Table 16. In most cases, the TCLP extract of a water sample is a filtrate of the water. In this project, to save the expense of performing solid content determinations and filtrations, the waters were analyzed and judged as hazardous or nonhazardous based on total concentrations.

\section{Characterization of the Other North Site Product Streams}

The remaining North Site materials were analyzed for toxicity using EPA Method 1311 (U.S. EPA 1990), which is described in the following Analytical Methods section. The unprocessed tar sand, unprocessed tar sand sludge, unprocessed western coal, unprocessed eastern coal, raw western oil shale, raw eastern oil shale, and material from the raw oil shale pile were also analyzed for their Btu content. ASTM Method D-2015 (ASTM 1983), which is also described in the Analytical Methods section, was used for this characterization. 


\section{Toxicity Testing}

For toxicity testing, regulated pesticides and herbicides were not analyzed because of process knowledge. None of the North Site materials requiring disposal were associated with any agricultural processes, and as a result, analyses for regulated pesticides and herbicides were not required.

Originally, the planned North Site material characterization included semiquantitative screening of some materials for regulated volatile compounds prior to TCLP extraction. However, it was decided that full-scale TCLP characterization should be performed to provide information for proper disposal of the materials as wastes, if they are not needed for future research.

\section{Analytical Methods}

\section{Characteristic of Imnitability}

A solid waste exhibits the characteristic of ignitability if a representative sample of the waste has any of the following properties (40 CFR 261.21, 1992):

1. It is a liquid, other than an aqueous solution containing less than $24 \%$ alcohol by volume and has a flash point less than $60^{\circ} \mathrm{C}\left(140^{\circ} \mathrm{F}\right)$, as determined by a Pensky-Martens Closed Cup Tester, using the test method specified in ASTM Standard D-93 (ASTM 1988), or a Setaflash Closed Cup Tester, using the test method specified in ASTM Standard D-3278 (ASTM 1988), or as determined by an equivalent test method approved by the EPA administrator under procedures set forth in 40 CFR 260.20 and 260.21 (1992).

2. It is not a liquid and is capable, under standard temperature and pressure, of causing fire through friction, absorption of moisture, or spontaneous chemical changes and, when ignited, burns so vigorously and persistently that it creates a hazard.

3. It is an ignitable compressed gas as defined in 49 CFR 173.300 (1992) and as determined by the test methods described in that regulation or equivalent test methods approved by the EPA administrator under 40 CFR 260.20 and 260.21 (1992).

4. It is an oxidizer as defined in 49 CFR 173.151 (1992).

The characteristic of ignitability was tested using ASTM Method D-93, Standard Test Method for Flash Point by Pensky-Martens Closed Tester (ASTM 1988). In this test, the sample is heated at a slow, constant rate with continual stirring. A small flame is directed into the cup at regular intervals with simultaneous interruption of stirring. The flash point is the lowest temperature at which application of the test flame causes the vapor above the sample to ignite. As specified in 40 CFR 261.21 (1992), a waste exhibits the characteristic of ignitability if it has a flash point less than $60^{\circ} \mathrm{C}\left(140^{\circ} \mathrm{F}\right)$. Criteria for judging the acceptability of results are given in the precisiou and bias statements in the ASTM method. A solid waste that exhibits the characteristic of ignitability has the EPA Hazardous Waste Number D001. 
The testing described above was used to examine the flash point of suspected materials that inay be classified as wastes. The North Site materials were also considered for the applicability of the other ignitability properties listed above; however, based on knowledge of the materials, these were determined to be nonapplicable.

\section{Characteristic of Corrosivity}

A solid waste exhibits the characteristic of corrosivity if a representative sample of the waste has either of the following properties (40 CFR 261.22, 1992):

1. It is aqueous and has a $\mathrm{pH}$ less than or equal to 2 or greater than or equal to 12.5, as determined by a pH meter using either an EPA test method or an equivalent test method approved by the EPA administrator under the procedures given in 40 CFR 260.20 and 260.21 (1992). The EPA test method for pH is specified as Method 9040 in "Test Methods for Evaluating Solid Waste, Physical/Chemical Methods," EPA Publication SW-846 (U.S. EPA 1986).

2. It is a liquid and corrodes steel (SAE 1020) at a rate greater than $6.35 \mathrm{~mm}$ $\left(0.250\right.$ inch) per year at a test temperature of $55^{\circ} \mathrm{C}\left(130^{\circ} \mathrm{F}\right)$ as determined by the test method specified in NACE (National Association of Corrosion Engineers) Standard TM-01-69. (NACE 1972) as standardized in "Test Methods for Evaluating Solid Waste, Physical/Chemical Methods," EPA Publication SW-846 (Method 1110-U.S. EPA 1986) or an equivalent test method approved by the EPA administrator under the procedures set forth in 40 CFR 260.20 and 40 CFR 260.21 (1992).

For the North Site materials in the water stream, the characteristic of corrosivity was tested by measuring their pH values using SW-846 Method 9040 (U.S. EPA 1986). In this method, the pH of the sample is determined electrometrically using either a glass electrode in combination with a reference potential or a combination electrode. The measuring instrument is calibrated using a series of standard solutions of known pH. Information on the accuracy of the method at various $\mathrm{pH}$ units is given in the method performance section of the procedure. If a material has a pH less than or equal to 2 or greater than or equal to 12.5, it exhibits the characteristic of corrosivity and is given the EPA Hazardous Waste Number D002.

\section{Characteristic of Reactivity}

A solid waste exhibits the characteristic of reactivity if a representative sample of the waste has any of the following properties (40 CFR 261.23, 1992):

1. It is normally unstable and readily undergoes violent change without detonating.

2. It reacts violently with water. 
3. It forms potentially explosive mixtures with water.

4. When mixed with water, it generates toxic gases, vapors or fumes in a quantity sufficient to present a danger to human health or the environment.

5. It is a cyanide or sulfide bearing waste which, when exposed to $\mathrm{pH}$ conditions between 2 and 12.5, can generate toxic gases, vapors or fumes in a quantity sufficient to present a danger to human health or the environment.

6. It is capable of detonation or explosive reaction if it is subjected to a strong igniting source or if heated under confinement.

7. It is readily capable of detonation or explosive decomposition or reaction at standard temperature and pressure.

8. It is a forbidden explosive as defined in 49 CFR 173.51 (1992), or a Class A explosive as defined in 49 CFR 173.53 (1992), or a Class B explosive as defined in 49 CFR 173.88 (1992).

The various North Site materials were considered for reactivity testing based on the properties listed above. However, knowledge of the materials indicated that these reactive properties were not applicable to them.

Characteristic of Toxicity: Method 1311 Toxicity Characteristic Leaching Procedure

To test a material for the characteristic of toxicity, an extract from a representative sample of the material was generated using EPA Method 1311, the Toxicity Characteristic Leaching Procedure (TCLP) (U.S. EPA 1990). Materials for which their TCLP extracts contain any of the regulated contaminants listed in Table 16 at a concentration equal to or greater than the regulatory level, are classified as hazardous based on toxicity. Method $1311 \mathrm{can}$ be found in Appendix II of 40 CFR 261 (1992). As mentioned, the methods specified for analysis of TCLP extracts are listed in Table 16 and can also be found in Tables 1 and 2 of Appendix III of 40 CFR 261 (1992). The method detection limits for analyzing TCLP extracts are given in the specific methods and are all well below the TCLP regulatory thresholds. The following QA/QC activities were performed for the North Site TCLP extractions.

- All data, including quality assurance data, are available for reference or inspection.

- A method blank for each batch of extraction fluid used was performed.

- A minimum of one blank (extraction fluid \#1) for every ten extractions that were performed in an extraction vessel was employed as a check for memory effects from the extraction equipment. 
- For each analytical batch (up to 20 samples), a matrix spike was performed to monitor the adequacy of the analytical method used on the TCLP extract and for determining any matrix interferences in analyte detection.

- All quality control messures described in the appropriate analytical methods were followed.

- TCLP extraction was performed within the following time period after sample collection: volatiles, 14 days; semivolatiles, 14 days; mercury, 28 days; and other metals, 180 days. Extraction of the samples was initiated as soon as possible. TCLP extracts were analyzed after generation and preservation within the following periods: volatiles, 14 days; semivolatiles, 40 days; mercury, 28 days; and other metals, 180 days. Preparative extraction for semivolatile organic compounds in the TCLP extracts was performed within 7 days after extract generation.

\section{Heat of Combustion}

Btu content of the heavy fuel oils was determined using ASTM Method D-240, Standard Test Method for Heat of Combustion of Liquid Hydrocarbon Fuels by Bomb Calorimeter (ASTM 1988). This ASTM method provides procedures for determining heat of combustion and is applicable to a variety of substances, but particularly to liquid hydrocarbon fuels of both low and high volatility. Heat of combustion is determined by burning a weighed sample in an oxygen bomb calorimeter under controlled conditions. The heat of combustion is calculated from temperature observations before, during, and after combustion, with proper allowance for thermochemical and heat transfer corrections. According to the method, duplicate results by the same operator should be considered suspect if they differ by more than $55 \mathrm{Btu} / \mathrm{hb}$.

Btu determinations on the unprocessed coal, tar sand, and oil shale materials were performed to provide information necessary for their disposal. ASTM Method D-2015, Standard Test Method for Gross Calorific Value of Solid Fuel by the Adiabatic Bomb Calorimeter (ASTM 1983), which involves burning a weighed sample in an adiabatic oxygen bomb calorimeter under controlled conditions, was used for these determinations. The calorific value is calculated from temperature measurements as described above. Duplicate results by the same laboratory on different days, using the same operator and equipment, should not be considered suspect unless they differ by more than 50 Btu/b on a dry weight basis.

\section{Analytical QA/QC}

Inorganic and organic Contract Laboratory Program (CLP) laboratories were used in phase I of this project to analyze samples and extracts of the North Site materials for verification of WRI's analytical results. CLP certification indicates that a high quality of data can be expected from the laboratory. The inorganic CLP laboratory was SVL Analytical, which is located in Kellogg, Idaho, and the organic CLP laboratory was Pace Laboratory, which is located in Lenexa, Kansas. There are no laboratories located in the nearby area that are both an inorganic and organic 
CLP laboratory. For CLP verification, composite samples and individual samples were split; one portion was analyzed by WRI, and one portion was analyzed by the CLP laboratory. For samples requiring TCLP extractions, samples were split and extracted at WRI; extract from one split was analyzed by WRI, and the extract from the other split was analyzed by the CLP laboratory. Splits of samples were also sent to Pace Laboratory for flesh point determinations.

The CLP laboratories encountered the same analytical problems as WRI in analyzing the oils and tars (i.e., dilution factors raising the method detection levels above regulatory values). Because analysis of these materials involved extensive analytical work and testing, many of the tars and oils were not analyzed by the CLP laboratories; however, materials, which were determined to contain levels of benzene exceeding the regulatory level, were sent to Pace Laboratory for verification of WRI's benzene data. Pace Laboratory and SVL Analytical also had similar difficulties in analyzing some of the materials that are listed under the water stream. Originally, it was planned that for decisions on classifying the North Site materials as hazardous or nonhazardous, WRI data and the CLP data must be in agreement (i.e., both showing the material to be hazardous or nonhazardous based on EPA criteria); however, due to the analytical difficulties, in some cases, only WRI data are available.

Splits of samples and extracts for the CLP laboratories were stored in a locked, refrigerated storage area until being shipped for analysis. Samples were shipped as soon as possible to meet analytical holding times. A chain-of-custody record and sample analysis request sheet accompanied the samples to the outside laboratories. Coolers containing ice substitute and packing material were used for shipping the samples. The chain-of-custody form and analytical request form were placed in a Ziplock bag and taped to the inside surface of the top of the cooler. A signed and dated custody seal was placed across the interface of the main body of the cooler and the cooler lid. Coolers were shipped to the laboratories via Federal Express. The person receiving the cooler at the CLP laboratory was requested to open the cooler, remove the enclosed sample documents, and record any problems on the chain-ofcustody form. Items that were checked are:

- Presence/absence of the chain-of-custody record(s)

- Presence/absence of the analytical request form(s)

- Condition of samples (intect, broken, lenking, etc.)

- Presence/absence of sample labels

Consistency of information between the following documents was also checked:

- Chain-of-custody records

- Sample labels

- Analytical request forms

The sample receiver contacted the sample shipper if damaged samples or discrepancies were found. Yellow chain-of-custody forms were to be sent to WRI as verification of sample receipt, and after analyses were completed, the original copy of the chain-of-custody form was to be returned with the samples. In some cases, the 
CLP laboratories deviated from these specifications of returning yellow copies at the time of sample receipt and original copies with the samples after analyses; however, during sample shipment, there was continuous communication with the laboratories by telephone to verify sample receipt and discuss any problems or discrepancies. After samples were received back from the CLP laboratory, they were added to their original product streams for appropriate disposal. Copies of the chain-of-custody records and sample analysis requeet forms for the samples and extracts, which were sent to the CLP laboratories, are included in Appendix C.

Analysis of Split Samples and Method Blanks. After preparation of the coal tar composite sample, the sample was split into four subsamples. Two of these were submitted to WRI for analysis, and two were submitted to the CLP laboratories for analysis. The splits were labeled such that the laboratories could not identify them as splits.

The tar sand sludge sample, crushed KC rock sample, and oil pitch composite sample were split, and each split was given to WRI extraction personnel for TCLP extraction as a blind sample. The extracts that resulted were also submitted blindly to WRI and the CLP laboratories for analysis.

In addition, as part of TCLP QAQC, a method blank was performed for each batch of TCLP extraction fluid that was used. Method blanks are performed to show any contamination of the extract from the reagents, water, or extraction equipment. To save on shipping costs, the method blanks were analyzed by WRI. Also, during the TCLP extractions, two sets of TCLP equipment blanks were generated using the extraction vessels used in phase I TCLP testing. Equipment blantes provide a check for memory effects from the extraction equipment. In addition to these QA/QC activities, specific QA/QC requirements outlined in the analytical methods for TCLP extracts were performed as specified.

Analytical Chain-of-Custody Procedures and Notebooks. As mentioned earlier, chain-of-custody procedures are being used in this cleanup project to ensure the integrity of samples from the time of collection through analysis and final disposition. For WRI TCLP extractions and analyses, chain-of-custody procedures, as previously described, were followed. Chain-of-custody seals, chain-of-custody forms, and analytical request forms were used. After their preparation, composite samples, split samples and blanks for QA/QC, and TCLP extracts were sealed with a custody seal. For chain-of-custody forms, the original and yellow sheets accompanied samples to the extraction and analytical personnel. Then the yellow sheet was returned to the project coordinator to verify sample receipt, and the original sheet was returned by the laboratory personnel with the remaining samples after the extractions or analyses were completed. Custody forms and analytical request forms were prepared and handled in a similar manner for analysis of TCLP extracts. Copies of the WRI sample analysis request forms and chain-of-custody forms are also included in Appendix C.

All information concerning preparation of composite samples, split samples for QA/QC, and TCLP extracts, as well as information on their analyses, was recorded in WRI project notebooks. These notebooks cross reference each other and the 
sampling logbook and page number deccribing sampling of the material. Copies of the notobook pagee documenting sample compositing, splitting, and TCLP extraction are also included in Appendix B.

\section{North Site Material Fandline Data Base}

To track materials in the North Site cleanup project, the North Site Materials Handling Data Base was created. This data base provides a quick and accurate means for producing reports on the status of the cleanup project. The materials handling data base currently contains an inventory of the materials requiring disposal or use, as well as, the product stream to which the material belongs, composite information, sampling and analytical information, analytical data, and hazard classification. This data base allows tracking of a material listed in the North Site inventory through the sampling and analytical processes, to a decision on hazard classification, and finally, when the project is completed, it will contain information on disposal or use of the material.

The data base aystem is written in FoxPro 2.0. Five primary and two helper data base files were developed. At the beginning of phase I, information, such as location, quantity, container size and type, storage environment, date accumulated, and date lest inspected, was entered into the data base for each of the materials. Then as the materials were divided into product streams and composite groups and sampling, compositing, and analysis started, information concerning these activities was added, along with results from the analyses. Based on the analytical results that are entered into the data base, hazard classifications are assigned to the materials. As the cleanup project proceeds, the data base will be expanded to include information concorning the activities in phases $\mathrm{I}, \mathrm{III}, \mathrm{N}$, and V.

\section{Photorraphs}

Photographs are a very useful record of field and laboratory activities. During phase I of this project, containers of the materials being stored at the North Site and the various activities involved in characterizing them were photographed. These photographs, which are included as Appendix D, show material storage, sampling activities, various steps involved in generating TCLP extracts, and various analytical activities and instrumentation involved in analyzing the North Site TCLP extracts and samples. 


\section{RESULTS AND DISCUSSION}

\section{Benulte from TCLP Extmotion of Componite and Individual Samples}

Composite and individual samples of materials from the North Site product streams were extrected using the TCLP (U.S. EPA 1990) to determine their hazard classification based on toxicity. The materials giving TCLP extracts that do not contain concentrations of any of the regulated analytes above their regulatory levels (listed in Table 16) pass the TCLP and are classified as nonhazardous based on toxicity. Conversely, any of the North Site materials that give TCLP extracts containing concentrations of one or more of the regulated analytes above their regulatory levels fail the TCLP and are classified as hazardous. Pass/ fail results for the materials that were characterized by TCLP extraction are listed in Table 17. Results based on both data from WRI analyses of TCLP extracts and data from the CLP laboratory analyoes are given. As shown in Table 17, all of the North Site materials tested by TCLP extraction pass and are nonhazardous based on toxicity. In addition, for all cases, WRI and CLP laboratory date give the same passing results.

Shown in Table 18 are the concentrations of the regulated metals in the TCLP extracts of the North Site materials, which were characterized by TCLP extraction (Table 17). Many of the concentrations of the regulated metals in the extracts are below the analytical detection limits; and the concentrations of those elements that are above the analytical detection limits are well below their TCLP regulatory values. In most cases, barium concentrations of approximately $0.04 \mathrm{mg} / \mathrm{L}$ wore detected in the TCLP method blanks, indicating a small of amount of barium contamination. This contamination is believed to originate from the chemicals used in preparing the TCLP extraction fluid and is not a problem for hazard classification because the action level for barium is $100 \mathrm{mg} / \mathrm{L}$. There is generally good agreement between WRI date and the data generated by SVL Analytical. In some cases, SVL had a lower detection limit than WRI, and more elements were detected in the extracts at very low concentrations. The minimum attainable detection limit can vary from sample-to-sample because of concentration/dilution action that may be necessary for analysis. As a result, analytical detection limits vary between WRI and SVL and also between samples. Listed in Table 19 are the WRI and SVL analytical detection limits that were in effect for metals analysis of the majority of the North Site TCLP extracts. All metals data generated by WRI and SVL Analytical in analyzing the TCLP extracts of the North Site samples can be found in Appendix $\mathbf{E}$.

As shown in Tables 17 and 18, the Ily ash composite sample was not characterized by TCLP for the regulated organic compounds. This is because the materials comprising this composite group are to be disposed in a landfill, and because of process knowledge concerning their generation, only TCLP metals data are required. The fly ash materials were added to the disposal list at the end of phase I, and to save time, their TCLP extract was analyzed by WRI only. 
Table 17. Characterization of North site Composite and Individual Samples by TCLP Extraction

Product Stroam/ Charactorization WRI Data CLP Data
Matorial

Unprocessed Tar Sand

Tar Sand

TCLP Motals

TCLP BNA's"

TCLP Volatiles

Pass

Pass

Pass Pass

Pass Pass

Tar Sand Sludge

TCLP Metals

TCLP BNA's

Pass

Pass

TCLP Volatiles

Pass

Pass

Pass Pass

Tar Sand Sludge

TCLP Metals

Split

TCLP BNA's

TCLP Volatiles

$\begin{array}{ll}\text { Pass } & \text { Pass } \\ \text { Pass } & \text { Pass } \\ \text { Pass } & \text { Pass }\end{array}$

Unprocessed Coals

$\begin{array}{llll}\text { Unprocessed Westorn } & \text { TCLP Motals } & \text { Pass } & \text { Pass } \\ \text { Coal } & \text { TCLP BNA's } & \text { Pass } & \text { Pass } \\ & \text { TCLP Volatiles } & \text { Pass } & \text { Pass } \\ \text { Unprocessed Eastern } & \text { TCLP Metals } & \text { Pass } & \text { Pass } \\ \text { Coal } & \text { TCLP BNA's } & \text { Pass } & \text { Pass } \\ & \text { TCLP Volatiles } & \text { Pass } & \text { Pass }\end{array}$

Raw Oil Shales

Raw Western Oil Shale

TCLP Motals

TCLP BNA's

TCLP Volatiles

Pass

Pass

Pass

Pass

Pass

TCLP Metals

Pass Pass

Rew Eastern Oil

TCLP BNA's

TCLP Volatiles

Pess

Pass

Shale.

Pass

Pass

Raw Oil Shale Pile

TCLP Metals

TCLP BNA's

Pess

Pass

TCLP Volatiles

Pass

Pass

Pass Pass

- Regulated semivolatile organic compounds, base, neutral, and acid (BNA's) 
Table 17. Characterisation of North Site Composite and Individual Samples by TCLP Extraction (continued)

\begin{tabular}{l}
$\begin{array}{l}\text { Product Stream/ Charactorization } \\
\text { Matorial }\end{array}$ \\
\hline
\end{tabular}

Spent Oil Shale, Processed Tar Sand, Activatod Chareoal

\begin{tabular}{|c|c|c|}
\hline Spent Oil Shale-1 & $\begin{array}{l}\text { TCLP Motals } \\
\text { TCLP BNA's" } \\
\text { TCLP Volatiles }\end{array}$ & $\begin{array}{l}\text { Pass } \\
\text { Pass } \\
\text { Pass }\end{array}$ \\
\hline Spent Oil Shale-2 & $\begin{array}{l}\text { TCLP Motals } \\
\text { TCLP BNA's } \\
\text { TCLP Volatiles }\end{array}$ & $\begin{array}{l}\text { Pass } \\
\text { Pass } \\
\text { Pass }\end{array}$ \\
\hline Spent Oil Shale Pile & $\begin{array}{l}\text { TCLP Motals } \\
\text { TCLP BNA's } \\
\text { TCLP Volatiles }\end{array}$ & $\begin{array}{l}\text { Pass } \\
\text { Pass } \\
\text { Pass }\end{array}$ \\
\hline Spont Tar Sand & $\begin{array}{l}\text { TCLP Metals } \\
\text { TCLP BNA's } \\
\text { TCLP Volatiles }\end{array}$ & $\begin{array}{l}\text { Pass } \\
\text { Pass } \\
\text { Pass }\end{array}$ \\
\hline Activated Chareoal & $\begin{array}{l}\text { TCLP Motals } \\
\text { TCLP BNA's } \\
\text { TCLP Volatiles }\end{array}$ & $\begin{array}{l}\text { Pass } \\
\text { Pass } \\
\text { Pass }\end{array}$ \\
\hline $\begin{array}{l}\text { Unused Activated } \\
\text { Charcoal }\end{array}$ & $\begin{array}{l}\text { TCLP Metals } \\
\text { TCLP BNA's } \\
\text { TCLP Volatiles }\end{array}$ & $\begin{array}{l}\text { Pass } \\
\text { Pass } \\
\text { Pass }\end{array}$ \\
\hline MG Fines, Char & $\begin{array}{l}\text { TCLP Metals } \\
\text { TCLP BNA's } \\
\text { TCLP Volatiles }\end{array}$ & $\begin{array}{l}\text { Pass } \\
\text { Pass } \\
\text { Pass }\end{array}$ \\
\hline
\end{tabular}

Miscellaneous Materials

\begin{tabular}{|c|c|c|}
\hline Oily Insulation & $\begin{array}{l}\text { TCLP Motals } \\
\text { TCLP BNA's } \\
\text { TCLP Volatiles }\end{array}$ & $\begin{array}{l}\text { Pass } \\
\text { Pass } \\
\text { Pass }\end{array}$ \\
\hline Tank Bottom Liner & $\begin{array}{l}\text { TCLP Metals } \\
\text { TCLP BNA's } \\
\text { TCLP Volatiles }\end{array}$ & $\begin{array}{l}\text { Pass } \\
\text { Pass } \\
\text { Pass }\end{array}$ \\
\hline $\begin{array}{l}\text { Evaporation Tank } \\
\text { Bottom Dirt }\end{array}$ & $\begin{array}{l}\text { TCLP Metals } \\
\text { TCLP BNA's } \\
\text { TCLP Volatiles }\end{array}$ & $\begin{array}{l}\text { Pass } \\
\text { Pass } \\
\text { Pass }\end{array}$ \\
\hline
\end{tabular}

- Regulated semivolatile organic compounds, base, neutral, and acid (BNA's) 
Table 17. Charaoterization of North site Composite and Individual Samples by TCLP Extraction (continued)

Product Stream/ Charactorization WRI Data CLP Data
Matorial

Miscellanoous Materials (continued)

Oily Dirt

TCLP Motals
TCLP BNA':
TCLP Volatiles

Pass

Pass

Pass

Pass

Pass

Pass

Sulfur

TCLP Motalo

TCLP BNA':

Pass

Pass

TCLP Volatiles

Pass

Pass

Pass

Pass

Crushed KC Rock

TCLP Motals

TCLP BNA's

TCLP Volatilee

Pass

Pass

Pass

Pass

Pass

Pass

Crushed KC Rock

TCLP Metals

TCLP BNA's

TCLP Volatiles

Pass

Pass

Split

TCLP Matals

Fly Ash

TCLP BNA':
TCLP Volatiles

Pass

Pass

Pass

Pess

Pass

Tars, Oils, end Hydrocarbon Liquids

Tank Bottom Heavy

Oil Solid

Oil Pitch

Oil Pitch Split

Unknown Materials

Pellets
TCLP Motals

TCLP BNA's

TCLP Volatiles

TCLP Metals

TCLP BNA's

TCLP Volatiles

TCLP Metals

TCLP BNA's

TCLP Volatiles
Pess

Pass

Pass

Pass

Pass

Pass

Pass

Pass

Pass

TCLP Motals

TCLP BNA's

TCLP Volatiles
Pass

Pass

Pass

Pass

Pass

Pass

Pess

Pass

Pass

\begin{tabular}{ll} 
Pass & Pass \\
\hline$d$ & -
\end{tabular}

- Regulated semivolatile organic compounds, base, neutral, and acid (BNA's)

Sample not submitted for analysis

c Analysis not required for landfill disposal due to process knowledge

d Sample not submitted for analysis-Organic screening shows that the sample does not contain any organic compounds that are amenable to GC analysis. 
Table 18. Concentrations of the Regulated Metals in the TCLP Extracts of the North Site Matoriale

\begin{tabular}{|c|c|c|c|c|c|c|c|}
\hline $\begin{array}{l}\text { Compoaite/ } \\
\text { Individual } \\
\text { Sample }\end{array}$ & $\begin{array}{l}\text { As } \\
(\overline{6} .0)^{a}\end{array}$ & $\underset{(100)}{\mathbf{B a}}$ & $\begin{array}{c}\text { Cd } \\
(1.0)\end{array}$ & $\underset{(6.0)}{\mathbf{C r}}$ & $\begin{array}{c}\mathrm{Pb} \\
(\mathbf{b} .0)\end{array}$ & $\underset{(0.2)}{\mathbf{H}_{\mathbf{g}}}$ & $\begin{array}{c}\text { Se } \\
(1.0)\end{array}$ \\
\hline
\end{tabular}

\section{Tar Sand}

WRI

SVL.

$\begin{array}{llllllll}\text { BDL } & 0.25 & \text { BDL } & 0.01 & \text { BDL } & \text { BDL } & \text { BDL } & \text { BDL } \\ \text { BDL } & 0.41 & \text { BDL } & 0.01 & \text { BDL } & \text { BDL } & \text { BDL } & \text { BDL }\end{array}$

Tar Sand Sludge

WRI

SVL

BDL 0.04 BDL BDL BDL BDL BDL BDL

BDL 0.03 BDL BDL BDL BDL BDL BDL

Tar Sand Sludge Split

WRI

SVL

BDL

0.04 BDL BDL BDL BDL BDL BDL

BDL 0.04 BDL BDL BDL BDL BDL BDL

Unprocessed

Western Coal

WRI

SVL

BDI

0.73

BDL · BDL

BDL BDL BDL BDL

BDL 0.80 BDL BDL BDL BDL BDL BDL

Unprocessed

Eastern Coal

WRI

SVL

$\begin{array}{llllllll}\text { BDL } & 0.05 & 0.02 & \text { BDL } & \text { BDL } & \text { BDL BDL BDL }\end{array}$

$\begin{array}{lllllll}\text { BDL } & 0.05 & 0.02 & \text { BDL } & \text { BDL } & \text { BDL BDL BDL }\end{array}$

Raw Weatern

Oil Shale

WRI

SVL

BDL 1.23 BDL BDL BDL BDL BDL BDL BDL 1.20 BDL BDL BDL BDL BDL BDL

Raw Eastern

Oil Shale

WRI

SVL

BDL 0.26

BDL 0.24

0.05

BDL BDL

BDL BDL BDL

$0.03 \quad 0.004$ BDL BDL $0.14 \quad$ BDL

Raw Oil Shale Pile

WRI

SVL

BDL $\quad 1.57$

BDL BDL BDL BDL BDL BDL $\begin{array}{llllll}\text { BDL } & 1.50 & \text { BDL } & 0.007 & \text { BDL } & \text { BDL }\end{array}$

Spent Oil Shale-1

WRI

SVL

BDL

BDL

0.14

0.17

BDL BDL

BDT BDI

BDL BDL BDL BDL BDL BDL

- The value given in parentheses is the regulatory level in $\mathrm{mg} / \mathrm{L}$ for each analyte.

b Below analytical detection limit

- SVL Analytical is the inorganic CLP laboratory that was used in phase I to verify WRI's analytical results. 
Table 18. Concentratione of the Regulited Metals in the TCLP Extracts of the North Site Materials (conitinued)

\begin{tabular}{lcccccccc}
\hline $\begin{array}{l}\text { Compositol } \\
\text { Individual }\end{array}$ & $\mathrm{As}_{\mathrm{s}}$ & $\mathrm{Ba}$ & $\mathrm{Cd}$ & $\mathrm{Cr}$ & $\mathrm{Pb}$ & $\mathrm{Hg}$ & $\mathrm{Se}$ & $\mathrm{Ag}$ \\
Sample & $(5.0)^{\circ}$ & $(100)$ & $(1.0)$ & $(5.0)$ & $(6.0)$ & $(0.2)$ & $(1.0)$ & $(\mathbf{( 5 . 0 )})$
\end{tabular}

Spent Oil Shale-2

WRI

SVLC

BDL 0.20 BDL BDL BDL BDL BDL BDL

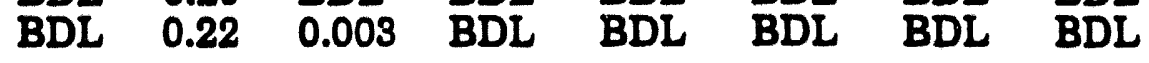

Spent Oil Shale Pile

WRI

SVL

BDL 0.10 BDL BDL BDL BDL BDL BDL

BDL 0.09 BDL 0.005 BDL BDL BDL BDL

Spent Tar Sand

WRI

SVL

BDL 0.48 BDL BDL BDL BDL BDL BDL

BDL 0.50 BDL BDL BDL BDL BDL BDL

Activated Charcoal

WRI

SVL

BDL 0.39 BDL BDL BDL BDL BDL BDL $\begin{array}{lllllll}\text { BDL } & 0.36 & \text { BDL } & 0.004 & \text { BDL } & \text { BDL } & \text { BDL }\end{array}$

Unused Activated Charcoal

$\begin{array}{lllllllll}\text { WRI } & \text { BDL } & 0.41 & \text { BDL } & \text { BDL } & \text { BDL } & \text { BDL } & \text { BDL } & \text { BDL } \\ \text { SVL } & \text { BDL } & 0.36 & \text { BDL } & \text { BDL } & \text { BDL } & \text { BDL } & \text { BDL } & \text { BDL }\end{array}$

MG Fines, Char

$\begin{array}{llllllll}\text { WRI } & \text { BDL } & 1.18 & \text { BDL BDL BDL BDL BDL BDL }\end{array}$ SVL BDL 1.28 BDL BDL BDL BDL BDL BDL

Oily Insulation

WRI

SVL

BDL 0.04 BDL BDL BDL BDL BDL BDL BDL 0.04 BDL BDL BDL BDL BDL BDL

Tank Bottom Liner

wR

SVI

BDL 0.10

BDL BDL BDL BDL BDL BDL

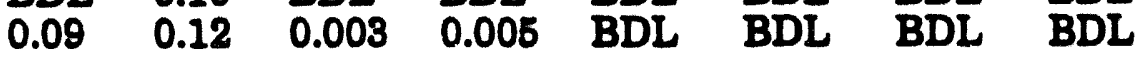

Evaporation

Tank Bottom Dirt

WRI.

SVL

BDL 0.09

$0.01 \quad 0.04$

BDL

BDL BDL BDL

0.63

0.08

0.0040 .04

BDL

$0.00050 .33 \quad$ BDL

Oily Dirt

WRI

BDL $\quad 0.06$

SVL

$0.20 \quad 0.07$

0.01

BDL BDL BDL BDL BDL 0.01 BDL 0.0003 BDL BDL

- The value given in parentheses is the regulatory level in $\mathrm{mg} / \mathrm{L}$ for each analyte.

b Below analytical detection limit

- SVL Analytical is the inorganic CLP laboratory that was used in phase I to verify WRI's analytical results. 
Table 18. Concentrations of the Regulated Metals in the TCLP Extracts of the North Site Materials (continued)

\begin{tabular}{|c|c|c|c|c|c|c|c|c|}
\hline $\begin{array}{l}\text { Composite/ } \\
\text { Individual } \\
\text { Semple }\end{array}$ & $\underset{(\bar{B} .0)^{\mathbf{a}}}{\text { ss }^{\mathrm{n}}}$ & $\underset{(100)}{B a}$ & $\underset{(1.0)}{C d}$ & $\begin{array}{c}\text { Cr } \\
(5.0)\end{array}$ & $\begin{array}{c}\mathrm{Pb} \\
(5.0)\end{array}$ & $\begin{array}{c}\mathrm{Hg}_{\mathbf{g}} \\
(0.2)\end{array}$ & $\begin{array}{c}\text { Se } \\
(1.0)\end{array}$ & $\begin{array}{c}A g \\
(5.0)\end{array}$ \\
\hline $\begin{array}{c}\text { Sulfur } \\
\text { WRI } \\
\text { SVIc }\end{array}$ & $\begin{array}{l}\text { BDL' } \\
\text { BDL }\end{array}$ & $\begin{array}{l}0.09 \\
0.10\end{array}$ & $\begin{array}{l}\text { BDL } \\
\text { BDL }\end{array}$ & $\begin{array}{l}0.03 \\
0.04\end{array}$ & $\begin{array}{l}\text { BDL } \\
\text { BDL }\end{array}$ & $\begin{array}{l}\text { BDL } \\
\text { BDL }\end{array}$ & $\begin{array}{l}\text { BDL } \\
\text { BDL }\end{array}$ & $\begin{array}{l}\text { BDL } \\
\text { BDL }\end{array}$ \\
\hline $\begin{array}{l}\text { Crushed KC Rock } \\
\text { WRI } \\
\text { SVL }\end{array}$ & $\begin{array}{l}\text { BDL } \\
\text { BDL }\end{array}$ & $\begin{array}{l}0.10 \\
0.10\end{array}$ & $\begin{array}{l}\text { BDL } \\
\text { BDL }\end{array}$ & $\begin{array}{l}\text { BDL } \\
\text { BDL }\end{array}$ & $\begin{array}{l}\text { BDL } \\
\text { BDL }\end{array}$ & $\begin{array}{l}\text { BDL } \\
\text { BDL }\end{array}$ & $\begin{array}{l}\text { BDL } \\
\text { BDL }\end{array}$ & $\begin{array}{l}\text { BDL } \\
\text { BDL }\end{array}$ \\
\hline $\begin{array}{l}\text { Crushed KC } \\
\text { Rock Split } \\
\text { WRI } \\
\text { SVL }\end{array}$ & $\begin{array}{l}\text { BDL } \\
\text { BDL }\end{array}$ & $\begin{array}{l}0.10 \\
0.10\end{array}$ & $\begin{array}{l}\text { BDL } \\
\text { BDL }\end{array}$ & $\begin{array}{l}\text { BDL } \\
\text { BDL }\end{array}$ & $\begin{array}{l}\text { BDL } \\
\text { BDL }\end{array}$ & $\begin{array}{l}\text { BDL } \\
\text { BDL }\end{array}$ & $\begin{array}{l}\text { BDL } \\
\text { BDL }\end{array}$ & $\begin{array}{l}\text { BDL } \\
\text { BDL }\end{array}$ \\
\hline $\begin{array}{c}\text { Fly Ash } \\
\text { WRI } \\
\text { SVLd }^{d}\end{array}$ & BDL & 0.90 & BDL & 0.01 & 0.20 & BDL & 0.10 & 0.02 \\
\hline $\begin{array}{l}\text { Tank Bottom } \\
\text { Heavy Oil Solid } \\
\text { WRI } \\
\text { SVL }\end{array}$ & $\begin{array}{l}0.41 \\
0.51\end{array}$ & $\begin{array}{l}0.11 \\
0.11\end{array}$ & $\begin{array}{l}0.02 \\
0.01\end{array}$ & $\begin{array}{l}\text { BDL } \\
0.009\end{array}$ & $\begin{array}{l}\text { BDL } \\
\text { BDL }\end{array}$ & $\begin{array}{l}\text { BDL } \\
0.0005\end{array}$ & $\begin{array}{l}\text { BDL } \\
0.09\end{array}$ & $\begin{array}{l}\text { BDL } \\
\text { BDL }\end{array}$ \\
\hline $\begin{array}{l}\text { Oil Pitch } \\
\text { WRI } \\
\text { SVL }\end{array}$ & $\begin{array}{l}\text { BDL } \\
\text { BDL }\end{array}$ & $\begin{array}{l}0.48 \\
0.51\end{array}$ & $\begin{array}{l}\text { BDL } \\
\text { BDL }\end{array}$ & $\begin{array}{l}\text { BDL } \\
\text { BDL }\end{array}$ & $\begin{array}{l}\text { BDL } \\
\text { BDL }\end{array}$ & $\begin{array}{l}\text { BDL } \\
\text { BDL }\end{array}$ & $\begin{array}{l}\text { BDL } \\
\text { BDL }\end{array}$ & $\begin{array}{l}\text { BDL } \\
\text { BDL }\end{array}$ \\
\hline $\begin{array}{l}\text { Oil Pitch Split } \\
\text { WRI } \\
\text { SVL }\end{array}$ & $\begin{array}{l}\text { BDL } \\
\text { BDL }\end{array}$ & $\begin{array}{l}0.40 \\
0.46\end{array}$ & $\begin{array}{l}\text { BDL } \\
\text { BDL }\end{array}$ & $\begin{array}{l}\text { BDL } \\
\text { BDL }\end{array}$ & $\begin{array}{l}\text { BDL } \\
\text { BDL }\end{array}$ & $\begin{array}{l}\text { BDL } \\
\text { BDL }\end{array}$ & $\begin{array}{l}\text { BDL } \\
\text { BDL }\end{array}$ & $\begin{array}{l}\text { BDL } \\
\text { BDL }\end{array}$ \\
\hline $\begin{array}{l}\text { Pellets } \\
\text { WRI } \\
\text { SVL }\end{array}$ & $\begin{array}{l}\text { BDL } \\
\text { BDL }\end{array}$ & $\begin{array}{l}0.72 \\
0.64\end{array}$ & $\begin{array}{l}\text { BDL } \\
\text { BDL }\end{array}$ & $\begin{array}{l}\text { BDL } \\
\text { BDL }\end{array}$ & $\begin{array}{l}\text { BDL } \\
\text { BDL }\end{array}$ & $\begin{array}{l}\text { BDL } \\
\text { BDL }\end{array}$ & $\begin{array}{l}\text { BDL } \\
\text { BDL }\end{array}$ & $\begin{array}{l}\text { BDL } \\
\text { BDL }\end{array}$ \\
\hline
\end{tabular}

a The value given in parentheses is the regulatory level in $\mathrm{mg} / \mathrm{L}$ for each analyte.

b Below analytical detection limit

- SVL Analytical is the inorganic CLP laboratory that was used in phase I to verify WRI's analytical results.

d Extract was not analyzed by SVL. 
Table 18. Analytical Detection Limits for Metals Analyses of the North Site TCLP Extracts, mg/L

\begin{tabular}{lll}
\hline Regulated Metal & WRI Detection Limit & SVL Detection Limit \\
\hline Arsenic & 0.10 & 0.04 \\
Barium & 0.01 & 0.01 \\
Cadmium & 0.01 & 0.002 \\
Chromium & 0.008 & 0.003 \\
Lead & 0.10 & 0.04 \\
Mercury & 0.002 & 0.0002 \\
Selenium & 0.10 & 0.04 \\
Silver & 0.02 & 0.002 \\
\hline
\end{tabular}

- SVL Analytical is the inorganic CLP laboratory that was used in phase I to verify WRI's analytical results.

None of the semivolatile organic compounds, which are regulated under the toxicity characteristic, were detected in the TCLP extracts of the North Site materials at levels above their analytical detection limits. The detection limits that were generally in effect for WRI and CLP analyses are listed in Table 20. WRI's detection limits were well below the TCLP action levels, while Pace chose to set their detection limits at the regulatory levels. None of the regulated semivolatile organic compounds were detected in the TCLP method blanks. Semivolatile organic data from analysis of the North Site TCLP extracts are included in Appendix E.

The general WRI and Pace analytical detsction limits for analysis of the TCLP regulated volatile organic compounds in the North Site TCLP extracts are listed in Table 21. As for the semivolatile organic analyses, WRI's detection limits were well below the TCLP action values, while Pace's detection limits were at the regulatory levels. As a result, WRI detected very low concentrations of some volatile compounds in the extracts, which were not reported by Pace. Methyl ethyl ketone, at concentrations less than $0.2 \mathrm{mg} / \mathrm{L}$, was detected by WRI in extracts of the evaporation tank bottom dirt, oily dirt, MG fines, char, western raw oil shale, eastern raw oil shale, raw oil shale pile, and oil pitch; and concentrations of benzene, at levels less than $0.2 \mathrm{mg} / \mathrm{L}$, were detected by WRI in extracts of the MG fines, char and oil pitch. These levels for both compounds are well below their regulatory values (Table 16). None of the regulated volatile organic compounds were detected in the TCLP method blanks. Volatile organic data from analysis of the North Site TCLP extracts are included in Appendix E. 
Table 20. Analytical Detection Limits for Semivolatile Organic Analyses of the North Site TCLP Extracts, mg/L

\begin{tabular}{lcc}
\hline Semivolatile Compound & WRI Detection Limit & Pace Detection Limit \\
\hline Pyridine & 0.10 & 5.0 \\
1,4-Dichlorobenzene & 0.04 & 7.5 \\
2-methylphenol & 0.04 & 200.0 \\
4-methylphenol/3-methyl & 0.04 & 200.0 \\
phenol & & \\
Hexachloroethane & 0.04 & 3.0 \\
Nitrobenzene & 0.04 & 2.0 \\
Hexachlorobutadiene & 0.04 & 0.5 \\
2,4,5-Trichlorophenol & 0.10 & 400.0 \\
2,4,6-Trichlorophenol & 0.04 & 2.0 \\
2,4-Dinitrotoluene & 0.04 & 0.13 \\
Hexachlorobenzene & 0.04 & 0.13 \\
Pentachlorophenol & 0.10 & 100.0 \\
\hline
\end{tabular}

- Pace Laboratory is the organic CLP laboratory that was used in phase I to verify WRI's analytical results.

Table 21. Analytical Detoction Limits for Volatile Organic Analyses of the North Site TCLP Extracts, mg/L

\begin{tabular}{lcc}
\hline Volatile Compound & WRI Detection Limit & Pace Detection Limit* \\
\hline Vinyl Chloride & 0.01 & 0.20 \\
1,1-Dichloroethene & 0.005 & 0.70 \\
Methyl ethyl ketone & 0.01 & 200.0 \\
Carbon Tetrachloride & 0.005 & 0.50 \\
Chlorobenzene & 0.005 & 100.0 \\
Trichloroethene & 0.005 & 0.50 \\
Chloroform & 0.005 & 6.0 \\
1,2-Dichloroethane & 0.005 & 0.50 \\
Tetrachloroethene & 0.005 & 0.70 \\
Benzene & 0.005 & 0.50 \\
\hline
\end{tabular}

- Pace Laboratory is the organic CLP laboratory that was used in phase I to verify WRI's analytical results. 


\section{TCLP QAQC Results}

TCLP QA/QC included TCLP method blanks, TCLP extraction of split samples, TCLP equipment blanks, field trip blanks for sampling materials for TCLP extraction, and analytical blank and matrix spike analyses. As mentioned above, none of the regulated TCLP analytes were detected above their analytical detection limits in any of the North Site TCLP method blanks, with the exception of barium at very low concentrations $(-0.04 \mathrm{mg} / \mathrm{L})$. This low level barium contamination is believed to originate from the chemicals used in preparing the TCLP extraction fluid. Because the action level for barium is $100 \mathrm{mg} / \mathrm{L}$, this low level contamination does not pose a problem.

Blind splits of the tar sand sludge sample, crushed KC rock sample, and oil pitch composite sample were extracted by WRI, and the resulting TCLP extracts were analyzed by WRI and the CLP laboratories. Results from those analyses are listed in Tables 22, 23, and 24. As shown in Tables 22 and 23, barium is the only TCLP regulated analyte that was detected in any of the extracts of the tar sand sludge and crushed $\mathrm{KC}$ rock at a concentration above the analytical detection limits. This was due to contamination as discussed above. In the extracts of the oil pitch composite, only barium, methyl ethyl ketone, and benzene were detected above the analytical detection limits (Table 23). Because Pace used such high detection limits, they did not report the low levels of organics detected in the oil pitch TCLP extracts by WRI. The metals data that were generated by WRI and SVL are in close agreement, as are the data for the extracts from the original samples and their splits.

Two sets of TCLP equipment blanks were run in the .raction vessels used for the North Site TCLP testing. These were perform _- check for any memory effects due to the extraction equipment. The equipment blanks consisted of TCLP extraction fluid rotated in the extraction vessels and filtered as specified in the TCLP. They were analyzed by WRI for the TCLP regulated analytes (Table 16). The equipment blanks generated in the zero-headspace extractors, which were used to generate TCLP extracts for analysis of volatile organic compounds, contained none of the TCLP regulated volatile organic compounds at levels above the detection limits given in Table 21. Blanks were also generated in the borosilicate glass bottles, which were used to generate TCLP extracts for analysis of metals and semivolatile organic compounds. These blanks contained none of the regulated metals or semivolatile organic compounds at levels above the detection limits given in Tables 19 and 20, with the exception of barium, which was present in all of the equipment blanks at levels of 0.03 to $0.04 \mathrm{mg} / \mathrm{L}$. This correlates with the barium contamination that was detected in the TCLP method blanks.

As shown in Table 12, a field trip blank was taken to the field for sampling the crushed KC rock, raw eastern oil shale, raw oil shale pile, tank bottom heavy oil solid, and pellets for TCLP extraction. A second field trip blank was also taken to the field for sampling the oil pitch materials for TCLP extraction. These blanks were analyzed by WRI and contained none of the TCLP regulated analytes above the analytical detection limits listed in Tables 19, 20, and 21. 
Table 22. Concentrations of the TCLP Regulated Analytes in TCLP Extracts of the Tar Sand Sludge Sample and Tar Sand Sludge Sample Split, mg/L

\begin{tabular}{|c|c|c|c|c|}
\hline TCLP Analyte & $\begin{array}{c}\text { Tar Sand } \\
\text { Sludge } \\
\text { WRI }\end{array}$ & $\begin{array}{l}\text { Tar Sand } \\
\text { Sludge } \\
\text { CLP }\end{array}$ & $\begin{array}{l}\text { Tar Sand } \\
\text { Sludge Split } \\
\text { WRI }\end{array}$ & $\begin{array}{l}\text { Tar Sand } \\
\text { Sludge Split } \\
\text { CLP }\end{array}$ \\
\hline Arsenic & $<0.10$ & $<0.04$ & $<0.10$ & $<0.04$ \\
\hline Barium & 0.039 & 0.029 & 0.043 & 0.044 \\
\hline Cadmium & $<0.01$ & $<0.002$ & $<0.01$ & $<0.002$ \\
\hline Chromium & $<0.008$ & $<0.004$ & $<0.008$ & $<0.004$ \\
\hline Lead & $<0.10$ & $<0.04$ & $<0.10$ & $<0.04$ \\
\hline Mercury & $<0.002$ & $<0.0002$ & $<0.002$ & $<0.0002$ \\
\hline Selenium & $<0.10$ & $<0.04$ & $<0.10$ & $<0.04$ \\
\hline Silver & $<0.02$ & $<0.003$ & $<0.02$ & $<0.003$ \\
\hline Pyridine & $<0.25$ & $<5.0$ & $<0.25$ & $<5.0$ \\
\hline 1,4-Dichlorobenzene & $<0.10$ & $<7.5$ & $<0.10$ & $<7.5$ \\
\hline 2-methylphenol & $<0.10$ & $<200.0$ & $<0.10$ & $<200.0$ \\
\hline 4-methylphenol/ & $<0.10$ & $<200.0$ & $<0.10$ & $<200.0$ \\
\hline \multicolumn{5}{|l|}{ 3-methylphenol } \\
\hline Hexachloroethane & $<0.10$ & $<3.0$ & $<0.10$ & $<3.0$ \\
\hline Nitrobenzene & $<0.10$ & $<2.0$ & $<0.10$ & $<2.0$ \\
\hline Hexachlorobutadiene & $<0.10$ & $<0.5$ & $<0.10$ & $<0.5$ \\
\hline 2,4,5-Trichlorophenol & $<0.25$ & $<400.0$ & $<0.25$ & $<400.0$ \\
\hline 2,4,6-Trichlorophenol & $<0.10$ & $<2.0$ & $<0.10$ & $<2.0$ \\
\hline 2,4-Dinitrotoluene & $<0.10$ & $<0.13$ & $<0.10$ & $<0.13$ \\
\hline Hexachlorobenzene & $<0.10$ & $<0.13$ & $<0.10$ & $<0.13$ \\
\hline Pentachlorophenol & $<0.25$ & $<100.0$ & $<0.25$ & $<100.0$ \\
\hline Vinyl Chloride & $<0.01$ & $<0.20$ & $<0.01$ & $<0.20$ \\
\hline 1,1-Dichloroethene & $<0.005$ & $<0.70$ & $<0.005$ & $<0.70$ \\
\hline Methyl ethyl ketone & $<0.01$ & $<200.0$ & $<0.01$ & $<200.0$ \\
\hline Carbon Tetrachloride & $<0.005$ & $<0.5$ & $<0.005$ & $<0.5$ \\
\hline Chlorobenzene & $<0.005$ & $<100.0$ & $<0.005$ & $<100.0$ \\
\hline Trichloroethene & $<0.005$ & $<0.5$ & $<0.005$ & $<0.5$ \\
\hline Chloroform & $<0.005$ & $<6.0$ & $<0.005$ & $<6.0$ \\
\hline 1,2-Dichloroethane & $<0.005$ & $<0.5$ & $<0.005$ & $<0.5$ \\
\hline Tetrachloroethene & $<0.005$ & $<0.7$ & $<0.005$ & $<0.7$ \\
\hline Benzene & $<0.005$ & $<0.5$ & $<0.005$ & $<0.5$ \\
\hline
\end{tabular}


Table 23. Concentrations of the TCLP Regulated Analytes in TCLP Extracts of the Crushed KC Rock Sample and Crushed KC Rock Sample Split, mg/L

\begin{tabular}{|c|c|c|c|c|}
\hline TCLP Analyte & $\begin{array}{l}\text { Crushed } \\
\text { KC Rock } \\
\text { WRI }\end{array}$ & $\begin{array}{l}\text { Crushed } \\
\text { KC Rock } \\
\text { CLP }\end{array}$ & $\begin{array}{l}\text { Crushed } \\
\text { KC Rock Split } \\
\text { WRI }\end{array}$ & $\begin{array}{l}\text { Crushed } \\
\text { KC Rock Split } \\
\text { CLP }\end{array}$ \\
\hline Arsenic & $<0.10$ & $<0.04$ & $<0.10$ & $<0.04$ \\
\hline Barium & 0.097 & 0.102 & 0.104 & 0.102 \\
\hline Cadmium & $<0.01$ & $<0.002$ & $<0.01$ & $<0.002$ \\
\hline Chromium & $<0.008$ & $<0.004$ & $<0.008$ & $<0.004$ \\
\hline Lead & $<0.10$ & $<0.04$ & $<0.10$ & $<0.04$ \\
\hline Mercury & $<0.002$ & $<0.0002$ & $<0.002$ & $<0.0002$ \\
\hline Selenium & $<0.10$ & $<0.04$ & $<0.10$ & $<0.04$ \\
\hline Silver & $<0.02$ & $<0.003$ & $<0.02$ & $<0.003$ \\
\hline Pyridine &.$<0.10$ & $<5.0$ & $<0.10$ & $<5.0$ \\
\hline 4-Dichlorobenzene & $<0.04$ & $<7.5$ & $<0.04$ & $<7.5$ \\
\hline 2-methylphenol & $<0.04$ & $<200.0$ & $<0.04$ & $<200.0$ \\
\hline 4-methylphenol/ & $<0.04$ & $<200.0$ & $<0.04$ & $<200.0$ \\
\hline \multicolumn{5}{|l|}{ 3-methylphenol } \\
\hline Hexachloroethane & $<0.04$ & $<3.0$ & $<0.04$ & $<3.0$ \\
\hline Nitrobenzene & $<0.04$ & $<2.0$ & $<0.04$ & $<2.0$ \\
\hline Hexachlorobutadiene & $<0.04$ & $<0.5$ & $<0.04$ & $<0.5$ \\
\hline 2,4,5-Trichlorophenol & $<0.10$ & $<400.0$ & $<0.10$ & $<400.0$ \\
\hline 2,4,6-Trichlorophenol & $<0.04$ & $<2.0$ & $<0.04$ & $<2.0$ \\
\hline 2,4-Dinitrotoluene & $<0.04$ & $<0.13$ & $<0.04$ & $<0.13$ \\
\hline Hexachlorobenzene & $<0.04$ & $<0.13$ & $<0.04$ & $<0.13$ \\
\hline Pentachlorophenol & $<0.10$ & $<100.0$ & $<0.10$ & $<100.0$ \\
\hline Vinyl Chloride & $<0.01$ & $<0.20$ & $<0.01$ & $<0.20$ \\
\hline 1,1-Dichloroethene & $<0.005$ & $<0.70$ & $<0.005$ & $<0.70$ \\
\hline Methyl ethyl ketone & $<0.01$ & $<200.0$ & $<0.01$ & $<200.0$ \\
\hline Carbon Tetrachloride & $<0.005$ & $<0.5$ & $<0.005$ & $<0.5$ \\
\hline Chlorobenzene & $<0.005$ & $<100.0$ & $<0.005$ & $<100.0$ \\
\hline Trichloroethene & $<0.005$ & $<0.5$ & $<0.005$ & $<0.5$ \\
\hline Chloroform & $<0.005$ & $<6.0$ & $<0.005$ & $<6.0$ \\
\hline 1,2-Dichloroethane & $<0.005$ & $<0.5$ & $<0.005$ & $<0.5$ \\
\hline Tetrachloroethene & $<0.005$ & $<0.7$ & $<0.005$ & $<0.7$ \\
\hline Benzene & $<0.005$ & $<0.5$ & $<0.005$ & $<0.5$ \\
\hline
\end{tabular}


Table 24. Concentrations of the TCLP Regulated Analytes in TCLP Extracts of the Oil Pitch Composite and Oll Pitch Composite Split, mg/L

\begin{tabular}{|c|c|c|c|c|}
\hline TCLP Analyte & $\begin{array}{l}\text { Oil Pitch } \\
\text { WRI }\end{array}$ & $\begin{array}{l}\text { Oil Pitch } \\
\text { CLP }\end{array}$ & $\begin{array}{l}\text { Oil Pitch } \\
\text { Split } \\
\text { WRI }\end{array}$ & $\begin{array}{l}\text { Oil Pitch } \\
\text { Split } \\
\text { CLP }\end{array}$ \\
\hline Arsenic & $<0.10$ & $<0.04$ & $<0.10$ & $<0.04$ \\
\hline Barium & 0.477 & 0.512 & 0.403 & 0.457 \\
\hline Cadmium & $<0.01$ & $<0.002$ & $<0.01$ & $<0.002$ \\
\hline Chromium & $<0.008$ & $<0.004$ & $<0.008$ & $<0.004$ \\
\hline Lead & $<0.05$ & $<0.04$ & $<0.05$ & $<0.04$ \\
\hline Mercury & $<0.002$ & $<0.0002$ & $<0.002$ & $<0.0002$ \\
\hline Selenium & $<0.10$ & $<0.04$ & $<0.10$ & $<0.04$ \\
\hline Silver & $<0.01$ & $<0.003$ & $<0.01$ & $<0.003$ \\
\hline Pyridine & $<0.25$ & $<5.0$ & $<0.25$ & $<5.0$ \\
\hline 1,4-Dichlorobenzene & $<0.10$ & $<7.5$ & $<0.10$ & $<7.5$ \\
\hline 2-methylphenol & $<0.10$ & $<200.0$ & $<0.10$ & $<200.0$ \\
\hline 4-methylphenol/ & $<0.10$ & $<200.0$ & $<0.10$ & $<200.0$ \\
\hline \multicolumn{5}{|l|}{ 3-methylphenol } \\
\hline Hexachloroethane & $<0.10$ & $<3.0$ & $<0.10$ & $<3.0$ \\
\hline Nitrobenzene & $<0.10$ & $<2.0$ & $<0.10$ & $<2.0$ \\
\hline Hexachlorobutadiene & $<0.10$ & $<0.5$ & $<0.10$ & $<0.5$ \\
\hline 2,4,5-Trichlorophenol & $<0.25$ & $<400.0$ & $<0.25$ & $<400.0$ \\
\hline 2,4,6-Trichlorophenol & $<0.10$ & $<2.0$ & $<0.10$ & $<2.0$ \\
\hline 2,4-Dinitrotoluene & $<0.10$ & $<0.13$ & $<0.10$ & $<0.13$ \\
\hline Hexachlorobenzene & $<0.10$ & $<0.13$ & $<0.10$ & $<0.13$ \\
\hline Pentachlorophenol & $<0.25$ & $<100.0$ & $<0.25$ & $<100.0$ \\
\hline Vinyl Chloride & $<0.01$ & $<0.20$ & $<0.01$ & $<0.20$ \\
\hline 1,1-Dichloroethene & $<0.005$ & $<0.70$ & $<0.005$ & $<0.70$ \\
\hline Methyl ethyl ketone & 0.026 & $<200.0$ & 0.027 & $<200.0$ \\
\hline Carbon Tetrachloride & $<0.005$ & $<0.5$ & $<0.005$ & $<0.5$ \\
\hline Chlorobenzene & $<0.005$ & $<100.0$ & $<0.005$ & $<100.0$ \\
\hline Trichloroethene & $<0.005$ & $<0.5$ & $<0.005$ & $<0.5$ \\
\hline Chloroform & $<0.005$ & $<6.0$ & $<0.005$ & $<6.0$ \\
\hline 1,2-Dichloroethane & $<0.005$ & $<0.5$ & $<0.005$ & $<0.5$ \\
\hline Tetrachloroethene & $<0.005$ & $<0.7$ & $<0.005$ & $<0.7$ \\
\hline Benzene & 0.19 & $<0.5$ & 0.15 & $<0.5$ \\
\hline
\end{tabular}


The data from analyses of the TCLP method blanks, TCLP split sample extracts, TCLP equipment blanks, and trip blanks for sampling materials for TCLP extraction are included in appendix $E$ of this report. QA/QC data from analyses of instrument blanks and matrix spike analyses are also included in Appendix $E$ with the corresponding sample data.

Btu Characterization of the Unprocessed Tar Sand, Unprocessed Coal, and Raw Oil Shale Streams

In addition to TCLP characterization, the composite groups within the unprocessed tar sand, unprocessed coal, and raw oil shale streams were analyzed by WRI for their Btu content. Some of these materials, if not all of them, will most likely be disposed in a landfill, and landfills require Btu information for acceptance of these types of materials. The Btu values of the unprocessed tar sands, unprocessed coals, and raw oil shales are listed in Table 25.

\section{Characterization of the North Site Waters}

\section{$\mathrm{pH}$ Values of the North Site Watere}

The materials comprising the North Site water stream were measured for their $\mathrm{pH}$ values to determine if they would be classified as hazardous based on corrosivity. As mentioned, an aqueous material having a $\mathrm{pH}$ less than or equal to 2 or greater than or equal to 12.5 , as determined by a $\mathrm{pH}$ meter using an approved method (40 CFR 261.22, 1992), exhibits the hazardous characteristic of corrosivity. The $\mathrm{pH}$ values of the North Site water individual and composite samples are listed in Table 26. None of these materials have $\mathrm{pH}$ values less than or equal to 2 or greater than or equal to 12.5. As a result, they are not hazardous based on their $\mathrm{pH}$ (corrosivity).

\section{North Site Waters Characterization for TCLP Regulated Analytes}

The North Site waters were analyzed for their total concentrations of the TCLP regulated analytes. As previously mentioned, in most cases, the TCLP extract of a water sample is a filtrate of the water, which is then analyzed for the regulated analytes. To save the time and expense of performing solid content determinations and filtrations, the waters were analyzed and judged as hazardous or nonhazardous based on their total concentrations. The concentrations of the regulated metals and organic compounds that were determined to be present in the North Site waters by both WRI and the CLP laboratories are listed in Tables 27-33. The only water that was not analyzed by the CLP laboratories is the CROWTM (Contained Recovery of Oil Wastes) water (Table 32), which was added to the disposal list late in phase I. Copies of the original data report forms that were received from the analytical laboratories for analysis of the North Site waters are included in Appendix E. 
Table 25. Btu Content of Unprocessed Tar Sand, Unprocessed Coal, and Raw Oil Shale Samplea

Composite/ndividual Sample

Btu Value

Tar Sand

Tar Sand Sludge

Tar Sand Sludge Split

$1,589 \mathrm{Btu} / \mathrm{b} \mathrm{b}^{*}$

$7,885 \mathrm{Btu} / \mathrm{b}$

$7,411 \mathrm{Btu} / \mathrm{b}$

Unprocesed Western Coal

Unprocessed Eastern Coal

9,772 Btu/b

$10,880 \mathrm{Btu} / \mathrm{b}$

Raw Western Oil Shale

Raw Eastern Oil Shale

$2,394 \mathrm{Btu}^{\mathrm{b}}$

Raw Oil Shale Pile

2,928 Btu

2,138 Btu

- Heating value

${ }^{b}$ Calorific value

Table 26. pH Values of the North Site Waterw

Composite/Individual Water Sample

pH

Retort Water

9.2

Graham Water

9.1

Tank Cleanout Water

8.3

Water Scavenger

2.5

Water, Coal Fines, Oil

7.9

Unidentified UCG Water

8.1

Hoe Creek Water

8.3

RM1 Water

8.3

CROW Water

6.9

Tank Bottom Water

5.9

Sludgy Water

7.1

Treolite Distillates

5.0

Free \& Distilled Water

7.0 
Table 27. Concentrations of the TCLP Regulated Analytes in the North Site Rotort Water and Graham Water, mg/L

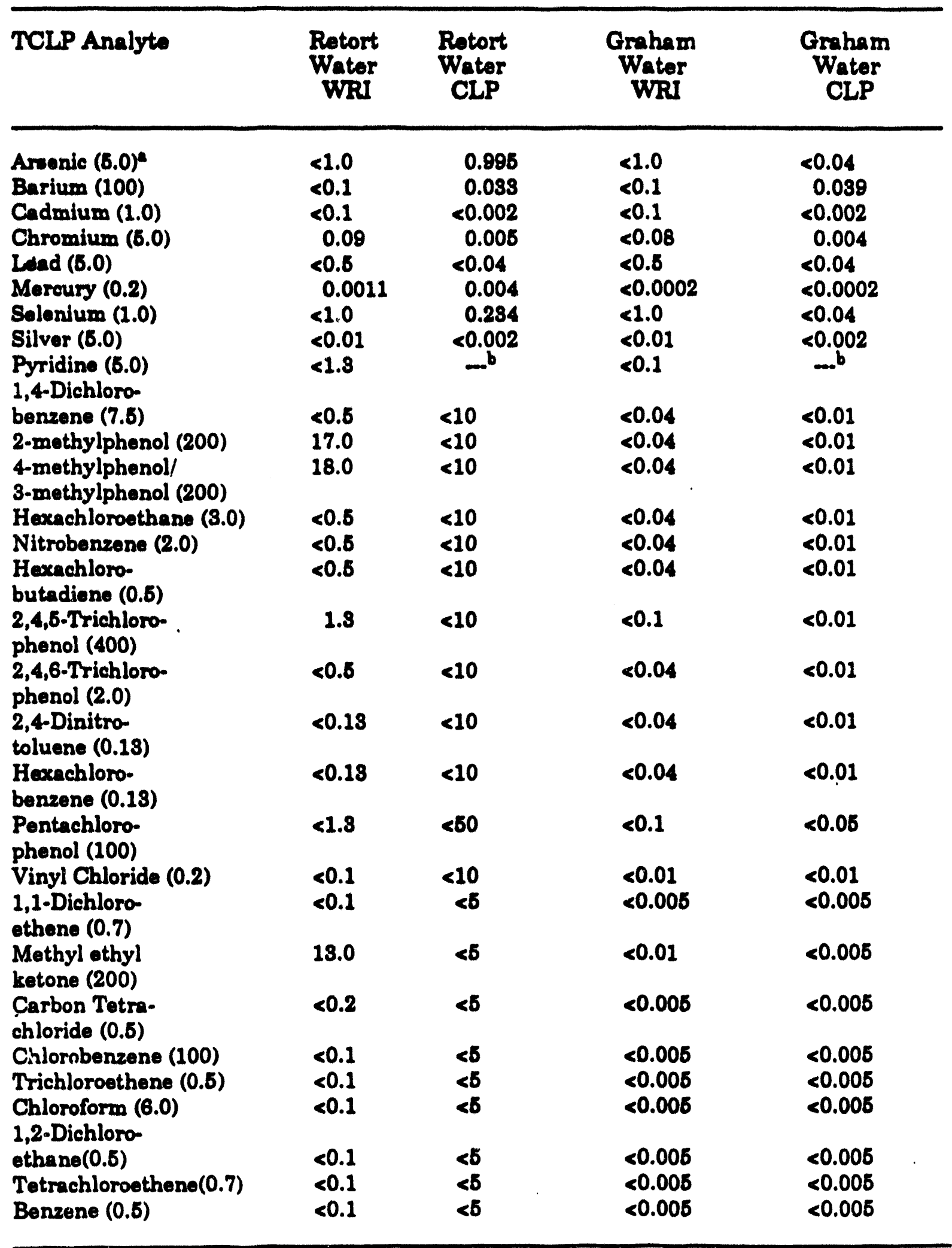

- The value given in parentheses is the regulatory level in ma/L for each analyte.

b No value reported 
Table 28. Concentrations of the TCLP Regulated Analytes in the North Site Tank Cleanout Water and Water Scavenger, mg/L

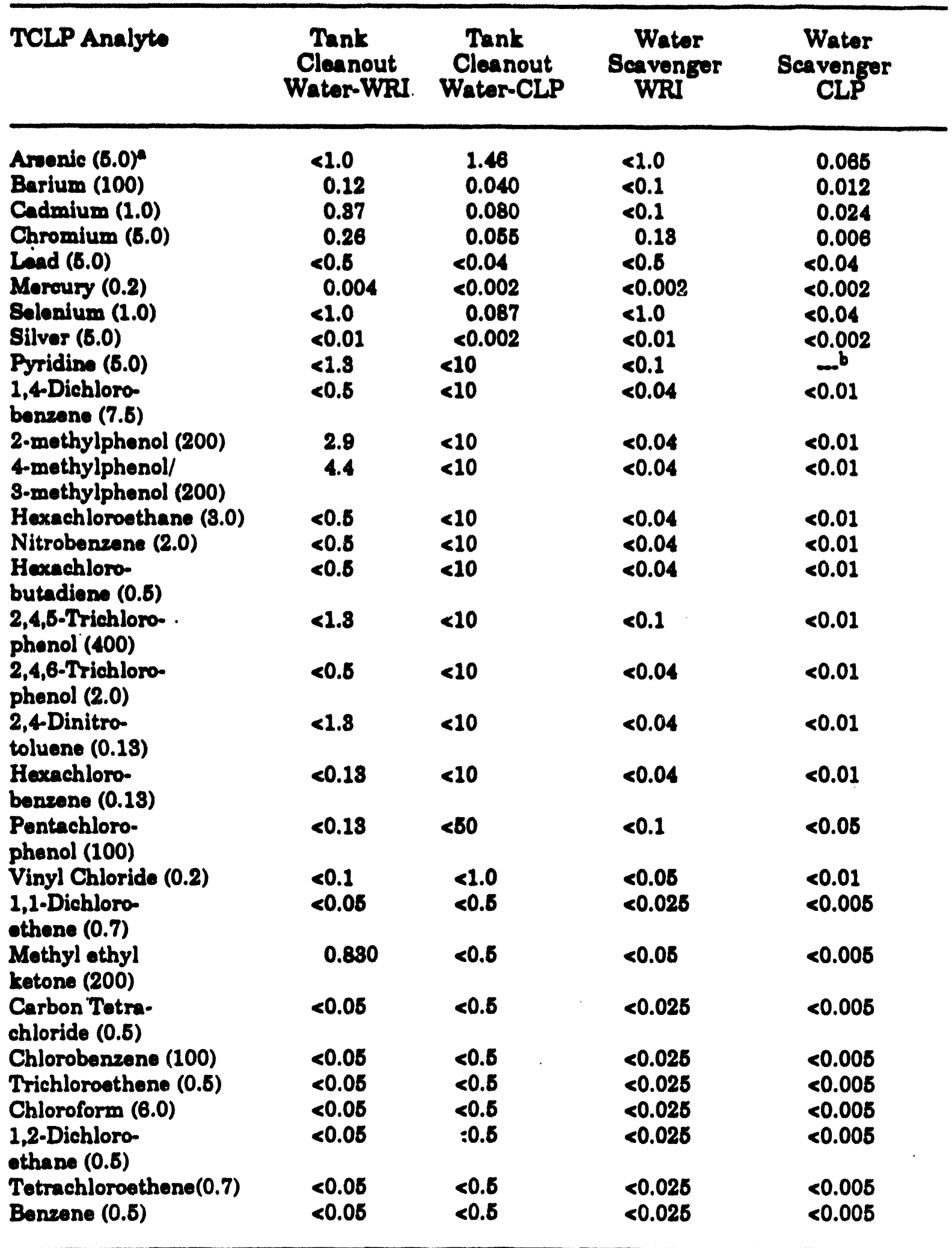

- The value given in parentheses is the regulatory level in mgl for each analyte.

b No value reported 
Table 29. Concentration of the TCLP Regulated Analytes in the North site Unidentifiod UCG Wator and Hoe Creek Water, mg/L

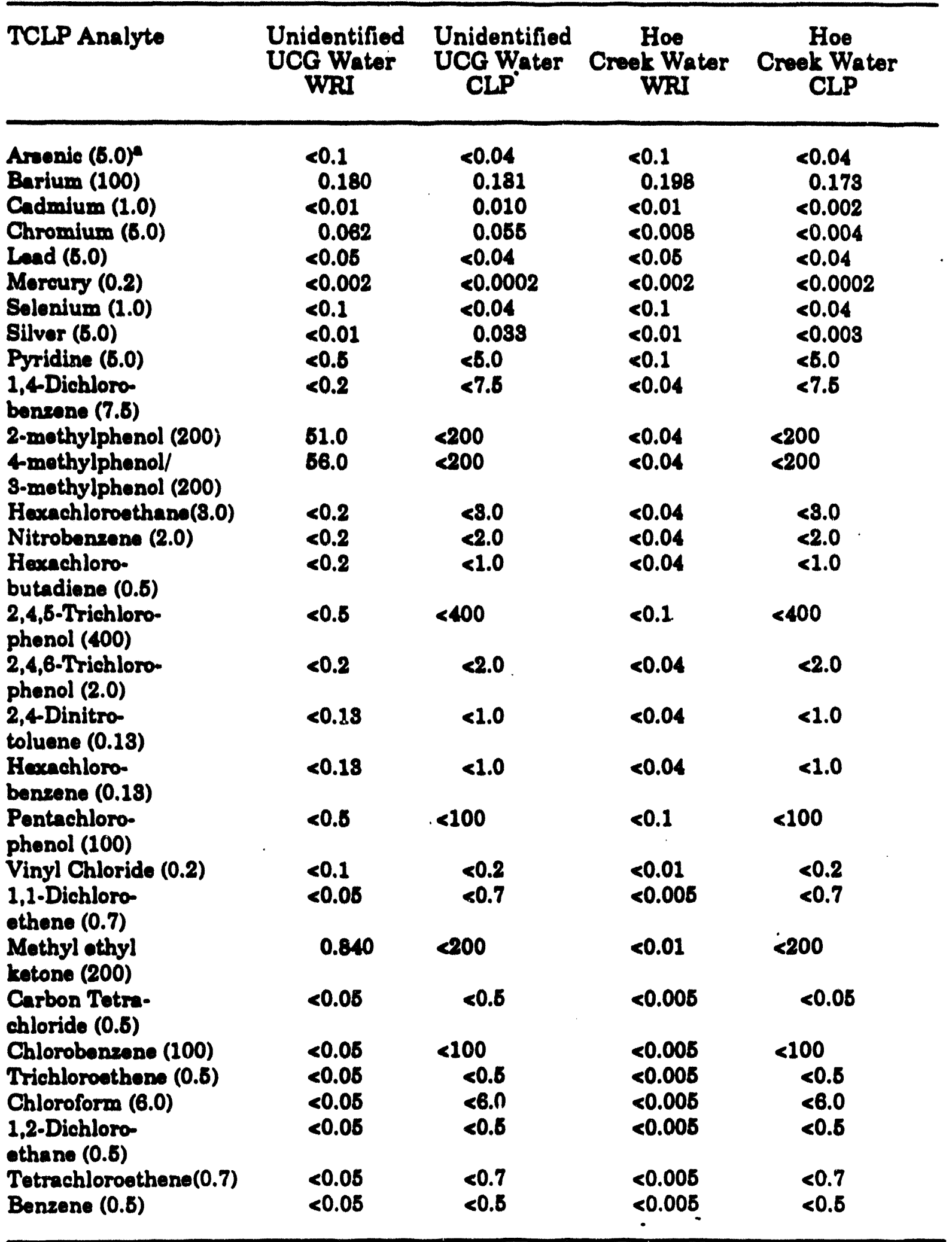

- The value given in parentheses is the regulatory level in $\mathrm{mg} / \mathrm{L}$ for each analyte. 
Table 80. Concentrations of the TCLP Regulated Analytes in the North Site Tank Bottom Water and Sludgy Water, mg/L

\begin{tabular}{|c|c|c|c|c|}
\hline TCLP Analyte & $\begin{array}{l}\text { Tank } \\
\text { Bottom } \\
\text { Water } \\
\text { WRI }\end{array}$ & $\begin{array}{c}\text { Tank } \\
\text { Bottom } \\
\text { Water } \\
\text { CLP }\end{array}$ & $\begin{array}{l}\text { Sluday } \\
\text { Water } \\
\text { WRI }\end{array}$ & $\begin{array}{c}\text { Sluday } \\
\text { Water } \\
\text { CLP }\end{array}$ \\
\hline 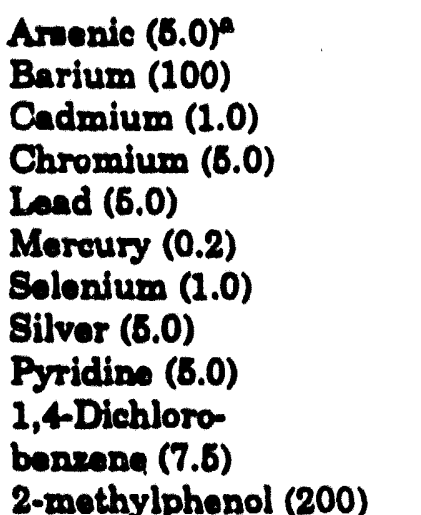 & $\begin{array}{l}16.0 \\
<0.1 \\
0.18 \\
0.17 \\
<0.6 \\
<0.02 \\
1.62 \\
<0.01 \\
<2.6 \\
<1.0 \\
<1.0\end{array}$ & $\begin{array}{c}8.47 \\
0.068 \\
0.082 \\
0.122 \\
<0.04 \\
0.01 \\
1.17 \\
0.010 \\
<0.2 \\
<0.2 \\
<0.2\end{array}$ & $\begin{array}{l}1.69 \\
1.68 \\
6.81 \\
2.72 \\
0.78 \\
<0.0002 \\
<1.0 \\
<0.01 \\
<0.31 \\
<0.18 \\
\\
0.18\end{array}$ & $\begin{array}{c}14.0 \\
3.42 \\
13.4 \\
6.01 \\
2.99 \\
0.14 \\
<0.04 \\
0.027 \\
<0.1 \\
<0.1 \\
\\
<0.1\end{array}$ \\
\hline $\begin{array}{l}\text { 2-methylphenol (200) } \\
\text { 4-methylphenol/ } \\
\text { 3-methylphenol (200) }\end{array}$ & $<1.0$ & $\begin{array}{l}<0.2 \\
<0.2\end{array}$ & 0.1 & $<0.1$ \\
\hline $\begin{array}{l}\text { Hexachloroethane }(3.0) \\
\text { Nitrobenzene (2.0) }\end{array}$ & $<1.0$ & $<0.2$ & $<0.18$ & $<0.1$ \\
\hline $\begin{array}{l}\text { Hexachloro } \\
\text { butadion }(0.5)\end{array}$ & $<0.5$ & $<0.2$ & $<0.18$ & $<0.1$ \\
\hline $\begin{array}{l}\text { 2,4,6-Triahloro } \\
\text { phonol }(400)\end{array}$ & $<1.0$ & $<0.2$ & $<0.81$ & $<0.1$ \\
\hline $\begin{array}{l}\text { 2,4,6-Trichloro- } \\
\text { phenol }(2.0)\end{array}$ & $<2.5$ & \$0.2 & $<0.18$ & $<0.1$ \\
\hline $\begin{array}{l}\text { 2,4-Dinitro- } \\
\text { toluene }(0.13)\end{array}$ & $<0.13$ & $<0.2$ & $<0.13$ & $<0.1$ \\
\hline $\begin{array}{l}\text { Hexachloro- } \\
\text { benzene }(0.13)\end{array}$ & $<0.13$ & $<0.2$ & $<0.13$ & $<0.1$ \\
\hline $\begin{array}{l}\text { Pentachloro- } \\
\text { phenol (100) }\end{array}$ & $<2.6$ & $<1.0$ & $<0.81$ & $<0.5$ \\
\hline Vinyl Chloride (0.2) & $<0.1$ & $<20$ & $<0.1$ & $<1.0$ \\
\hline $\begin{array}{l}\text { 1,1-Dichloro- } \\
\text { thene }(0.7)\end{array}$ & $<0.1$ & $<10$ & $<0.05$ & $<0.6$ \\
\hline $\begin{array}{l}\text { Methyl ethyl } \\
\text { kotone (200) }\end{array}$ & 2.0 & $<10$ & 0.1 & $<0.6$ \\
\hline $\begin{array}{l}\text { Carbon Tetra- } \\
\text { chloride }(0.5)\end{array}$ & $<0.1$ & $<10$ & $<0.05$ & $<0.6$ \\
\hline Chlorobenzene $(100)$ & $<0.1$ & $<10$ & $<0.08$ & $<0.6$ \\
\hline Trichloroethen $(0.5)$ & $<0.1$ & $<10$ & $<0.05$ & $<0.5$ \\
\hline Chloroform (6.0) & $<0.1$ & $<10$ & $<0.06$ & $\begin{array}{l}<0.5 \\
<0.5\end{array}$ \\
\hline $\begin{array}{l}\text { 1,2-Dichloro- } \\
\text { ethane }(0.5)\end{array}$ & $<0.1$ & $<10$ & $<0.05$ & $<0.5$ \\
\hline $\begin{array}{l}\text { Tetrachloroethene }(0.7) \\
\text { Benzene }(0.5)\end{array}$ & $\begin{array}{l}<0.1 \\
<0.1\end{array}$ & $\begin{array}{l}<10 \\
<10\end{array}$ & $\begin{array}{l}<0.05 \\
<0.05\end{array}$ & $\begin{array}{l}<0.5 \\
<0.5\end{array}$ \\
\hline
\end{tabular}

- The value given in parentheses is the regulatory level in mg/L for each analyte. 
Table 81. Concentrations of the TCLP Regulated Analytes in the North Site Treolite Distlllates and Free and Distilled Water, mg/L

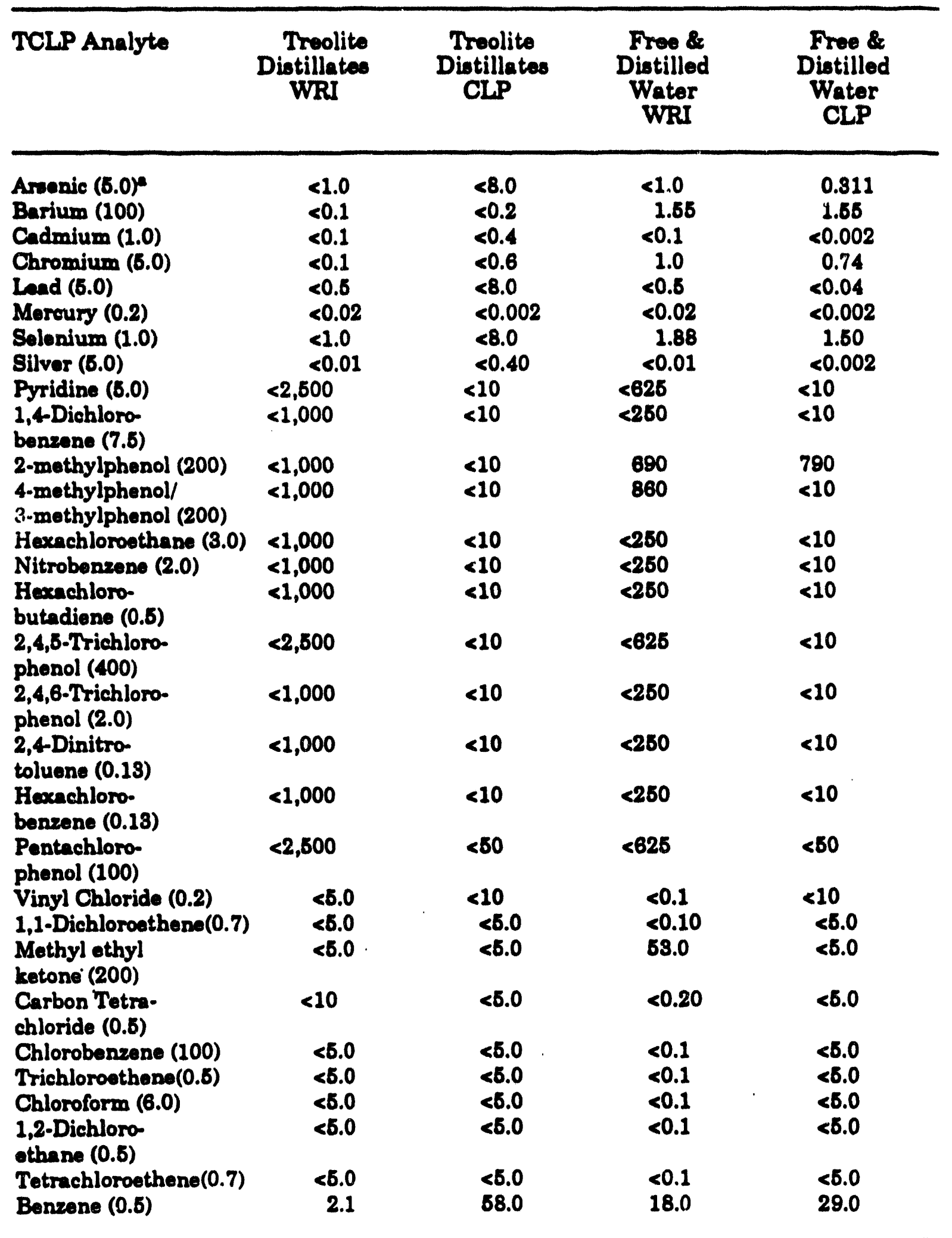

- The value given in parentheses is the regulatory level in mgll for each unalyte. 
Table 32. Concentrations of the TCLP Regulated Analytes in the North Site RM1 Water and CROW Water, mg/L

TCLP Analyte

RM1 Water

WRI

RMI Water
CLP

CROW Water

WRI

Arsenic (5.0)

Barium (100)

Cadmium (1.0)

Chromium (5.0)

Lead (5.0)

Mercury (0.2)

Selenium (1.0)

Silver (5.0)

Pyridine (5.0)

1,4-Dichlorobenzene (7.5)

2-methylphenol (200)

4-methylphenol/

$<0.1$

0.061

$<0.04$

$<0.1$

$<0.01$

$<0.008$

$<0.05$

$<0.002$

$<0.1$

0.053

2.45

$<0.002$

$<0.01$

$<0.004$

$<0.008$

$<0.04$

$<0.05$

$<0.0002$

$<0.002$

$<0.01$

$<0.1$

$<0.04$

$<0.1$

$<0.003$

$<0.01$

$<0.04$

$<0.04$

$<5.0$

$<7.5$

$<0.25$

$<0.1$

$<0.04$

$<200$

$<0.1$

$<200$

$<0.1$

3-methylphenol (200)

Hexachloroethane (3.0)

$<0.04$

$<0.04$

$<3.0$

$<0.1$

$<0.04$

$<2.0$

$<0.1$

Hexachlorobutadiene (0.5)

$<0.1$

2,4,6-Trichlorophenol (400)

$<0.04$

$<1.0$

$<0.1$

$<400$

$<2.0$

$<0.25$

$<0.04$

$<1.0$

$<0.1$

$<0.04$

$<1.0$

$<0.1$

Hexachlorobenzene ( $(0.13)$

$<0.1$

$<100$

$<0.1$

$<0.01$

$<0.005$

$<0.2$

$<0.25$

Vinyl Chloride (0.2)

1,1-Dichloroethene (0.7)

Methyl ethyl ketone (200)

$<0.01$

$<0.005$

$<0.7$

$<0.05$

$<0.025$

$<200$

$<0.05$

$<0.005$

$<0.5$

$<0.025$

Chlorobenzene (100)

Trichloroethene (0.5)

Chloroform (6.0)

$<0.005$

$<100$

$<0.025$

$<0.5$

$<0.025$

$<0.005$

$<6.0$

$<0.025$

$<0.005$

$<0.5$

$<0.025$

$<0.005$

$<0.7$

$<0.025$

Benzene (0.5)

$<0.005$

$<0.5$

0.200

- The value given in parentheses is the regulatory level in $m g / L$ for each analyte. 
Table 33. Concentrations of the TCLP Regulated Analytes in the North Site Water, Coal Fines, Oil Sample, mg/L

TCLP Analyte

Water, Coal Fines, Oil WRI

Water, Coal Fines, Oil CLP

Arsenic (5.0)

$<2.0$

$<0.04$

Barium (100)

0.153

0.115

Cadmium (1.0)

$<0.1$

$<0.002$

Chromium (5.0)

0.11

$<0.004$

Lead (5.0)

$<0.5$

$<0.04$

Mercury (0.2)

$<0.02$

$<0.002$

Selenium (1.0)

$<1.0$

$<0.04$

Silver (5.0)

$<0.1$

$<0.003$

Pyridine (5.0)

$<0.5$

$<5.0$

1,4-Dichlorobenzene (7.5)

$<0.2$

$<7.5$

2-methylphenol (200)

71.0

96.0

$<200$

4-methylphenol/

3-methylphenol (200)

Hexachloroethane (3.0)

Nitrobenzene (2.0)

$<0.2$

$<200$

Hexachlorobutadiene (0.5)

$<0.2$

$<3.0$

$<0.2$

$<2.0$

2,4,5-Trichlorophenol (400)

$<0.5$

$<1.0$

2,4,6-Trichlorophenol (2.0)

$<0.2$

$<400$

2,4-Dinitrotoluene (0.13)

$<0.13$

$<2.0$

$<0.13$

$<1.0$

Hexachlorobenzene (0.13)

$<0.5$

Pentachlorophenol (100)

Vinyl Chloride (0.2)

$<0.05$

$<1.0$

1,1-Dichloroethene (0.7)

Methyl ethyl ketone (200)

$<0.025$

14.0

$<0.025$

$<0.025$

$<0.025$

$<100$

$<0.025$

$<0.2$

$<0.7$

Carbon Tetrachloride (0.5)

Chlorobenzene (100)

Trichloroethene (0.5)

$<0.025$

$<200$

Chloroform (6.0)

1,2-Dichloroethane (0.5)

Tetrachloroethene (0.7)

Benzene (0.5)

$<0.025$

$<0.5$

$<100$

$<0.5$

$<6.0$

$<0.5$

0.16

$<0.7$

$<0.5$

- The value given in parentheses is the regulatory level in $\mathrm{mg} / \mathrm{L}$ for each analyte. 
The concentrations of the TCLP regulated analytes in the retort water are listed in Table 27. The data generated by WRI show that this water does not contain any of the TCLP regulated analytes in concentrations above the TCLP action levels, and as a result, is not hazardous based on toxicity. The data generated by SVL Analytical also show this for the TCLP regulated metals. However, for many of the semivolatile and volatile organic analytes, the detection limits reported by Pace are above the regulatory levels, and no TCLP pass/fail decision can be made based on the Pace data. In error, Pace did not analyze the retort water for pyridine.

The concentrations of the TCLP regulated analytes in the graham water are also listed in Table 27. The data generated by WRI and the CLP laboratories show that the graham water does not contain any of the TCLP regulated analytes at levels above the TCLP regulatory values. The only analyte for which WRI data are not confirmed by the CLP laboratory is pyridine. In error, Pace did not analyze the graham water for pyridine. However, based on the data shown in Table 27, the graham water is aiso nonhazardous in terms of toxicity.

WRI data listed in Table 28 show that the tank cleanout water and the water scavenger do not contain any of the TCLP regulated analytes in concentrations above their TCLP action levels, and as a result, pass TCLP characterization for toxicity. The data generated by SVL Analytical (Table 28) verify that the tank cleanout water and the water scavenger pass TCLP for the regulated metals. However, once again, for many of the organic analytes in the tank cleanout water, the detection limits reported by Pace (Table 28) are above the regulatory levels, and no TCLP pass/fail decision can be made for this water based on the data from Pace. In addition, Pace once again did not analyze the water scavenger for pyridine.

WRI data listed in Table 29 show that the unidentified UCG and Hoe Creek "aters do not contain any of the TCLP regulated analytes in concentrations above s heir TCLP action levels, and as a result, are not hazardous based on toxicity. The data generated by SVL Analytica: (Table 29) verify that the unidentified UCG and Hoe Creek waters pass TCLP for the regulated metals. For most of the TCLP regulated semivolatile and volatile organic compounds, Pace used a detection limit equal to the regulatory level (Table 29) and verified WRI's results. However, for hexachlorobutadiene, 2,4-dinitrotoluene, and hexachlorobenzene, the Pace detection limits are above the regulatory levels and do not give information that can be used to decide if the waters pass TCLP for those compounds.

WRI and SVL data listed in Table 30 show that the tank bottom water fails TCLP characterization for arsenic and selenium, and as a result, this water is hazardous based on toxicity. The concentration of arsenic determined to be present in the tank bottom water by WRI is $15.0 \mathrm{mg} / \mathrm{L}$, while SVL detected $8.5 \mathrm{mg} / \mathrm{L}$. The toxicity characteristic regulatory level for arsenic is $5.0 \mathrm{mg} / \mathrm{L}$. The concentrations of 
selenium that were detected in the tank bottom water by WRI and SVL are 1.6 and $1.2 \mathrm{mg} / \mathrm{L}$, respectively. Selenium has a regulatory value of $1.0 \mathrm{mg} / \mathrm{L}$.

WRI and SVL data listed in Table 30 also show that the sludgy water fails TCLP characterization and is hazardous based on toxicity. WRI data show the concentration of cadmium $(5.3 \mathrm{mg} / \mathrm{L})$ in the sludgy water exceeding the TCLP regulatory level of $1.0 \mathrm{mg} / \mathrm{L}$. In addition to showing cadmium (13.4 $\mathrm{mg} / \mathrm{L}$ ) at a concentration above $1.0 \mathrm{mg} / \mathrm{L}$, SVL data show the concentrations of arsenic (14.0 $\mathrm{mg} / \mathrm{L})$ and chromium $(6.0 \mathrm{mg} / \mathrm{L})$ in the sludgy water to be above their regulatory value of $5.0 \mathrm{mg} / \mathrm{L}$. Although arsenic and chromium were not detected above their regulatory levels by WRI, and the concentration of cadmium that was determined by the two laboratories vary, the water is shown to be hazardous by both laboratories. Data generated by WRI and/or Pace show that the concentrations of the regulated organic compounds in the sludgy water do not exceed TCLP regulatory levels.

Data resulting from analyses of the treolite distillates and free and distilled water for the TCLP regulated analytes are listed in Table 31. As shown by the organic data generated by WRI and Pace, both laboratories could not lower their analytical detection limits below TCLP regulatory levels for many of the semivolatile and volatile organic compounds. This was due to sample dilution, which was required to analyze these materials. SVL also had difficulty lowering their detection limits for analysis of the treolite distillates for arsenic, lead, and selenium. Despite the analytical difficulties, both of these materials were determined to be hazardous as wastes, based on their concentrations of benzene, r.t. ch has an action level of $0.5 \mathrm{mg} / \mathrm{L}$. WRI detected $2.1 \mathrm{mg} / \mathrm{L}$ of benzene in the

$\therefore \therefore$ distillate, and Pace reported $58 \mathrm{mg} / \mathrm{L}$. In the free and distilled water, 18.0 $\therefore .0 \mathrm{mg} / \mathrm{L}$ of benzene were reported by WRI and Pace, respectively. In addition, the free and distilled water also fails TCLP based on concentrations of cresol and selenium present in the material. WRI detected $1.9 \mathrm{mg} / \mathrm{L}$ selenium in the free and distilled water, while SVL reported finding $1.5 \mathrm{mg} / \mathrm{L}$. The TCLP action level for selenium is $1.0 \mathrm{mg} / \mathrm{L}$. 1,550 mg/L total cresol (2-, 3-, 4-methylphenol) was reported by WRI to be present in the free and distilled water, while Pace detected $709 \mathrm{mg} / \mathrm{L}$. The concentrations of the organic analytes detected by WRI and Pace vary considerably. This may be due to nonhomogeneity and difficulty of the analyses.

WRI data listed in Table 32 show that the RMI and CROW waters do not contain any of the TCLP regulated analytes in concentrations above their TCLP action levels, and as a result, are not hazardous based on toxicity. As mentioned earlier, the CROW water was added to the disposal list very late in phase I and was analyzed by only WRI. The data generated by SVL Analytical (Table 32) verify that the RM1 water passes TCLP for the regulated metals. For most of the TCLP regulated semivolatile and volatile organic compounds, Pace used a detection limit equal to or below the appropriate regulatory level (Table 32) and verified WRI's results. However, for hexachlorobutadiene, 2,4-dinitrotoluene, and 
hexachlorobenzene, the Pace detection limits are above the regulatory levels and do not give information that can be used to decide if the RMI water passes TCLP for those compounds.

WRI data listed in Table 33 show that the water, coal fines, oil material does not contain any of the TCLP regulated analytes in concentrations above their TCLP action levels, and as a result, is not hazardorss based on toxicity. The data generated by SVL Analytical (Table 33) verify that the water, coal fines, oil material passes TCLP for the regulated metals. For most of the TCLP regulated semivolatile and volatile organic compounds, Pace used a detection limit equal to the appropriate regulatory level (Table 33) and verified WRI's results. However, for hexachlorobutadiene, 2,4-dinitrotoluene, and hexachlorobenzene, the Pace detection limits are above the regulatory levels and do not give information that can be used to decide if this material passes TCLP for those compounds.

To summarize the information, which is discussed above and presented in Tables 27-33, Table 34 lists the TCLP pass/fail results for each of the composite groups in the North Site water stream based on their concentrations of the toxicity characteristic regulated analytes. In addition, Table 35 shows those water composite groups that fail the toxicity characteristic and the constituents and their concentrations that cause them to fail.

In addition to the tank bottom water, sludgy water, treolite distillates, and free and distilled water being hazardous, investigation of the nature of the graham waters led to information showing that these materials contain radium 226. Information listed in Table 7 shows that containers 1113-1120 are represented by the graham water composite group. Of these, water stored in drums 1113, 1114, 1117, and 1118 contain 116 picocuries of radium 226, and water stored in drums 1115, 1116, 1119, and 1120 contain 12.4 picocuries of radium 226.

\section{Analysis of the QAVQC Field Trip Blants for Sampling the Waters}

Metals, semivolatile organic, and volatile organic field trip blanks were taken to the field during sampling of the North Site water containers. These blanks were analyzed during analysis of the water samples to check for any contamination of the waters due to the field environment, including sample storage and transportation. The blanks were analyzed by WRI, and none of the TCLP regulated analytes were detected at concentrations above the analytical detection limits, with the exception of chromium, which was reported at $0.1 \mathrm{mg} / \mathrm{L}$. The regulatory action level for chromium is $5.0 \mathrm{mg} / \mathrm{L}$, and the sludgy water, which is the only water that contains hazardous levels of chromium, was reported to contain much higher levels at 2.7 and $6.0 \mathrm{mg} / \mathrm{L}$. Results from analysis of the field trip blanks, as well as, QA QC data from analyses of instrument blanks and matrix spikes are included with the water data in Appendix $\mathbf{E}$. 
Table 34. TCLP Pass/Fall Reaults for the North Site Water Stream Based on Total Concentration of TCLP Regulated Analytes in the Water

\begin{tabular}{|c|c|c|c|}
\hline Composite & Characterization & WRI Data & CLP Data \\
\hline $\begin{array}{l}\text { Tank Bottom Water } \\
\text { pH }=5.9\end{array}$ & $\begin{array}{l}\text { TCLP Metal } \\
\text { TCLP BNA's } \\
\text { TCLP Volatiles }\end{array}$ & $\begin{array}{l}\text { Fagil } \\
\text { Pass }\end{array}$ & Fquil $_{b}$ \\
\hline $\begin{array}{l}\text { Retort Water } \\
\mathrm{pH}=9.2\end{array}$ & $\begin{array}{l}\text { TCLP Metals } \\
\text { TCLP BNA's } \\
\text { TCLP Volatiles }\end{array}$ & $\begin{array}{l}\text { Pass } \\
\text { Pass } \\
\text { Pass }\end{array}$ & \\
\hline $\begin{array}{l}\text { Graham Water } \\
\mathrm{pH}=9.1\end{array}$ & $\begin{array}{l}\text { TCLP Metals } \\
\text { TCLP BNA's } \\
\text { TCLP Volatiles }\end{array}$ & $\begin{array}{l}\text { Pass } \\
\text { Pass } \\
\text { Pass }\end{array}$ & $\frac{\text { Pass }}{\text { Pass }}$ \\
\hline $\begin{array}{l}\text { Tank Cleanout Water } \\
\mathrm{pH}=9.3\end{array}$ & $\begin{array}{l}\text { TCLP Metals } \\
\text { TCLP BNA's } \\
\text { TCLP Volatiles }\end{array}$ & $\begin{array}{l}\text { Pass } \\
\text { Pass } \\
\text { Pass }\end{array}$ & $\begin{array}{l}\text { Pags } \\
-b \\
-b\end{array}$ \\
\hline $\begin{array}{l}\text { Sludgy Water } \\
\text { pH }=7.1\end{array}$ & $\begin{array}{l}\text { TCLP Metals } \\
\text { TCLP BNA's } \\
\text { TCLP Volatiles }\end{array}$ & $\begin{array}{l}\text { Fail } \\
\text { Pass } \\
\text { Pass }\end{array}$ & $\begin{array}{l}\text { Fail } \\
\text { Pags }\end{array}$ \\
\hline $\begin{array}{l}\text { Treolite Distillate } \\
\mathrm{pH}=5.0\end{array}$ & $\begin{array}{l}\text { TCLP Metals } \\
\text { TCLP BNA's } \\
\text { TCLP Volatiles }\end{array}$ & $\begin{array}{l}\text { Pasos } \\
\text { Fail }\end{array}$ & $\underset{b}{a b}$ \\
\hline $\begin{array}{l}\text { Free \& Distilled } \\
\text { Water } \\
\text { pH }=7.0\end{array}$ & $\begin{array}{l}\text { TCLP Metals } \\
\text { TCLP BNA's } \\
\text { TCLP BNA's }\end{array}$ & $\begin{array}{l}\text { Fail } \\
\text { Fail } \\
\text { Fail }\end{array}$ & $\begin{array}{l}\text { Fail } \\
\text { Fail } \\
\text { Fail }\end{array}$ \\
\hline $\begin{array}{l}\text { Water Scavenger } \\
\mathrm{pH}=2.5\end{array}$ & $\begin{array}{l}\text { TCLP Metals } \\
\text { TCLP BNA's } \\
\text { TCLP Volatiles }\end{array}$ & $\begin{array}{l}\text { Pass } \\
\text { Pass } \\
\text { Pass }\end{array}$ & $\frac{\text { Pass }}{\text { Pass }}$ \\
\hline $\begin{array}{l}\text { Water, Coal Fines, } \\
\text { Oil } \\
\text { pH }=7.9\end{array}$ & $\begin{array}{l}\text { TCLP Metals } \\
\text { TCLP BNA's } \\
\text { TCLP Volatiles }\end{array}$ & $\begin{array}{l}\text { Pass } \\
\text { Pass } \\
\text { Pass }\end{array}$ & $\frac{\text { Pass }}{\text { Pass }}$ \\
\hline $\begin{array}{l}\text { Unidentified } \\
\text { UCG Water } \\
\text { pH }=8.1\end{array}$ & $\begin{array}{l}\text { TCLP Metals } \\
\text { TCLP BNA's } \\
\text { TCLP Volatiles }\end{array}$ & $\begin{array}{l}\text { Pass } \\
\text { Pass } \\
\text { Pass }\end{array}$ & $\begin{array}{l}\text { Pags } \\
\text { Pass }\end{array}$ \\
\hline $\begin{array}{l}\text { Hoe Creek Water } \\
\text { pH }=8.3\end{array}$ & $\begin{array}{l}\text { TCLP Metals } \\
\text { TCLP BNA's } \\
\text { TCLP Volatiles }\end{array}$ & $\begin{array}{l}\text { Pass } \\
\text { Pasa } \\
\text { Pass }\end{array}$ & $\begin{array}{l}\text { Pass } \\
\text { Pass }\end{array}$ \\
\hline $\begin{array}{l}\text { RM-1 Water } \\
\text { pH }=\mathbf{8 . 3}\end{array}$ & $\begin{array}{l}\text { TCLP Metals } \\
\text { TCLP BNA's } \\
\text { TCLP Volntiles }\end{array}$ & $\begin{array}{l}\text { Pase } \\
\text { Pass } \\
\text { Pass }\end{array}$ & $\frac{\text { Pagss }}{\text { Pass }}$ \\
\hline $\begin{array}{l}\text { CROW Water } \\
\text { pH }=6.9\end{array}$ & $\begin{array}{l}\text { TCLP Motals } \\
\text { TCLP BNA's } \\
\text { TCLP Volatiles }\end{array}$ & $\begin{array}{l}\text { Pase } \\
\text { Peas } \\
\text { Peso }\end{array}$ & $m_{d}^{d}$ \\
\hline
\end{tabular}

- Regulated semivolatile organic compounds, base, neutral, and acid (BNA's)

b The method detection limit is greater than the regulatory level. As a result, no pass/fail decision can be made.

c Sample not analyzed for pyridine

d Sample not submitted for analysis 
Table 35. Composite Groups in the North Site Water Stream Falling TCLP Regulatory Levels

\begin{tabular}{|c|c|c|c|c|}
\hline \multirow[t]{2}{*}{ Composite } & \multirow{2}{*}{$\begin{array}{l}\text { Container No. } \\
\text { Ropresented }\end{array}$} & \multicolumn{3}{|c|}{ Failure } \\
\hline & & WRI & & $\overline{\text { CLP }}$ \\
\hline $\begin{array}{l}\text { Tank Bottom } \\
\text { Water }\end{array}$ & $824,825,889,947$ & $\begin{array}{l}\text { As: } 15 \mathrm{ppm} \\
\text { Se: } 1.6 \mathrm{ppm}\end{array}$ & $\begin{array}{l}\text { As: } \\
\text { Se: }\end{array}$ & $\begin{array}{l}8.5 \mathrm{ppm} \\
1.2 \mathrm{ppm}\end{array}$ \\
\hline Sludgy Water & 550 & Cd: $5.3 \mathrm{ppm}$ & $\begin{array}{l}\text { As: } \\
\text { Cd: } \\
\text { Cr: }\end{array}$ & $\begin{array}{r}14.0 \mathrm{ppm} \\
13.4 \mathrm{ppm} \\
6.0 \mathrm{ppm}\end{array}$ \\
\hline $\begin{array}{l}\text { Treolite } \\
\text { Distillates }\end{array}$ & 618 & Benzene: 2 ppm & Ben & ene: $58 \mathrm{ppm}$ \\
\hline $\begin{array}{l}\text { Free \& } \\
\text { Distilled } \\
\text { Water }\end{array}$ & 1201 & $\begin{array}{l}\text { Se: } 1.9 \text { ppm } \\
\text { Cresol: } 1,550 \mathrm{ppm} \\
\text { Benzene: } 18 \mathrm{ppm}\end{array}$ & $\begin{array}{l}\text { Se: } 1 \\
\text { Cres } \\
\text { Ben: }\end{array}$ & $\begin{array}{l}.5 \mathrm{ppm} \\
\text { ol: } 709 \mathrm{ppm} \\
\text { ene: } 29 \mathrm{ppm}\end{array}$ \\
\hline
\end{tabular}

Results from Analyeis of the Tars, Oils, and Hydrocarbon Liquids

Two of the composite groups in the tar, oil, and hydrocarbon liquid stream were characterized by TCLP extraction and were determined to be nonhazardous based on toxicity. These are the oil pitch and tank bottom heavy oil solid (Tables 17 and 18). The remaining materials under this product stream were to be characterized for their total concentrations of the TCLP regulated analytes due to the difficulty in applying the TCLP.

As discussed in the description of the analyses of the North Site tars, oils, and hydrocarbon liquids, due to the nature of these materials, difficulties were encountered by both WRI and the CLP laboratories in analyzing them for the TCLP regulated analytes. High levels of dilution that were required for analyses caused the analytical detection limits for many of the regulated TCLP a nalytes to be greater than the TCLP action levels. An approach was taken to a nalyze the materials for their benzene concentrations, as well as their concentrations of the regulated metals, to identify those materials that can be classified as hazardous based on their concentrations of these regulated analytes and to reduce the number of materials requiring more difficult analyses. 


\section{Results from Benzene Analysis of the Tars, Oils, and Hydrocarbon Liquids}

The concentrations of benzene, which were determined to be present in the composite and individual samples that are part of the tar, oil, and hydrocarbon liquid stream, are listed in Table 36. All of the samples listed were analyzed for their benzene concentrations by WRI, and nine of the materials were also sent to Pace for benzene analysis to verify WRI's results. The benzene concentrations listed in Table 36 all exceed the TCLP action level of $0.5 \mathrm{mg} / \mathrm{L}$ for wastes. If the samples listed in Table 36 were tested by TCLP, and the total amount of benzene they contain was extracted into the TCLP extract, the concentration of benzene would be diluted by the extraction fluid. For solid materials, the dilution factor would be equal to 20 , and for multiphasic samples, the dilution factor would be less than 20 and would vary depending on the percent solids in the sample. To determine the percent solids in the oily materials as specified in the TCLP would have been extremely costly and time consuming for this project. As a result, it was decided to evaluate the toxicity of the oily materials based on their total concentration of benzenc, which means that all of the materials listed in Table 36 are hazardous if they require disposal. This approach may seem very conservative; however, if the benzene concentrations listed in Table 36 are divided by 20 , which is a higher d... .tion factor than would be required for the multiphasic wastes, the resulting ucentrations for all of the materials, except the tank oil and tank bottom heavy oil, still exceed the TCLP action level of $0.5 \mathrm{mg} / \mathrm{L}$ as shown in Table 37. Benzene data from WRI and Pace analyses of the materials in the tar, oil, and hydrocarbon liquid stream can be found in Appendix $E$.

Table 36. Concentrations of Benzene in Composite and Individual Samples of the Tar, Oil, and Hydrocarbon Liquid Stream, ppm

\begin{tabular}{|c|c|c|}
\hline \multirow{2}{*}{$\begin{array}{c}\text { Composite/Individual } \\
\text { Sample }\end{array}$} & \multicolumn{2}{|c|}{ Benzene } \\
\hline & WRI & CLP \\
\hline $\begin{array}{l}\text { Shale Oil-1 } \\
\text { Shale Oil-2 } \\
\text { Shale Oil-3 } \\
\text { Shale Oil Distillates. } \\
\text { Tar Sand Heavy Oil } \\
\text { Heavy Oil Plus Coal } \\
\text { Dirty Oil \& Sludge } \\
\text { Coal Tar } \\
\text { Heavy Oil } \\
\text { Heavy Fuel Oil } \\
\text { Heavy Crude Oil } \\
\text { Tank Bottom } \\
\text { Tank Oil } \\
\text { Distillate Light Oil } \\
\text { Oily Material Plus Water } \\
\text { Tank Bottom Heavy Oil }\end{array}$ & $\begin{array}{l}45 \\
26 \\
36 \\
260 \\
18 \\
290 \\
>2.6 \\
2,900 \\
130 \\
13 \\
21 \\
130 \\
7.2 \\
7,700 \\
330 \\
2.1\end{array}$ & 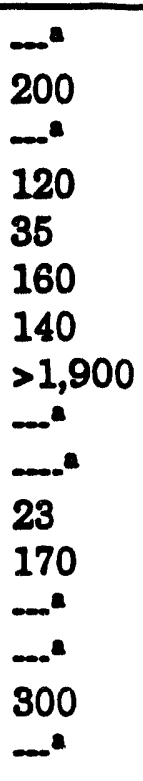 \\
\hline
\end{tabular}

- Sample not analyzed 
Table 37. Concentrations of Benzene in Composite and Individual Samples of the Tar, Oll, and Bydrocarbon Liquid Stream Divided by a Dilution Factor of 20, ppm

\begin{tabular}{lll}
\hline $\begin{array}{l}\text { Composite/Individual } \\
\text { Sample }\end{array}$ & \multicolumn{1}{c}{ Benzene } \\
\cline { 2 - 3 } & \multicolumn{1}{c}{ WRI } & CLP \\
\hline Shale Oil-1 & $45 / 20=2.2$ & - \\
Shale Oil-2 & $26 / 20=1.3$ & $200 / 20=10$ \\
Shale Oil-3 & $36 / 20=1.8$ & - \\
Shale Oil Distillates & $260 / 20=13$ & $120 / 20=6$ \\
Tar Sand Heavy Oil & $18 / 20=0.9$ & $35 / 20=1.7$ \\
Heavy Oil Plus Coal & $290 / 20=14.5$ & $160 / 20=8$ \\
Dirty Oil \& Sludge & $>2.6 / 20=>0.13$ & $140 / 20=7$ \\
Coal Tar & $2,900 / 20=145$ & $>1,900 / 20=>95$ \\
Heavy Oil & $130 / 20=6.5$ & - \\
Heavy Fuel Oil & $13 / 20=0.65$ & - \\
Heavy Crude Oil & $21 / 20=1.0$ & $23 / 20=1.1$ \\
Tank Bottom & $130 / 20=6.5$ & $170 / 20=8.5$ \\
Tank Oil & $7.2 / 20=0.36$ & - \\
Distillate Light Oil & $7,700 / 20=385$ & - \\
Oily Materia! Plus Water & $330 / 20=16.5$ & $300 / 20=15$ \\
Tank Bottom Heavy Oil & $2.1 / 20=0.10$ & - \\
\hline
\end{tabular}

- Sample not analyzed

For the most part, the benzene concentrations determined by WRI and Pace (Table 36) vary between the two laboratories. This is most likely due to the nature of the materials. However, data from WRI and Pace are in agreement, showing concentrations of benzene above the TCLP action level (Tables 36 and 37).

\section{Volatile Analysis of the Tank Oil and Tank Water}

Tank oil and tank water samples were analyzed by WRI for their concentrations of the other regulated volatile organic compounds. Concentrations of trichloroethene greater than the TCLP regulatory level of $0.5 \mathrm{mg} / \mathrm{L}$ were detected in both materials. The tank water, which would not be diluted as part of the TCLP extraction, contains $2.2 \mathrm{ppm}$ trichloroethene, and the tank oil contains $1,400 \mathrm{ppm}$. The concentration of trichloroethene in the tank oil would exceed the regulatory level even with a dilution factor of 20 applied. As a result, both the tank oil and tank water are hazardous. Data from WRI analysis of the tank oil and tank water are included in Appendix E. 
Other Orgenic Analytes Determined in the Tars, Oils, and Hydrocarbon Liquids Above TCLP Action Levels

Trichloroethene was also determined to be present in the shale oil.- 1 and heavy oil composites at concentrations above the TCLP regulatory value of $0.5 \mathrm{mgl}$. WRI detected $0.71 \mathrm{ppm}$ trichloroethene in the shale oil-1 composite sample and $43 \mathrm{ppm}$ trichloroethene in the heavy oil composite sample. Both of these composite groups are hazerdous as wastes based on their benzene concentrations (Tables 36 and 37). Forty-three parts per million of trichloroethene, even with a dilution factor of 20 applied, also causes the heavy oil to be hazardous. WRI detected $410 \mathrm{ppm}$ methy! ethyl ketone in both the coal tar composite sample and the distillate light oil composite sample. The TCLP regulatory level for methyl ethyl ketone is $200 \mathrm{mg} /$. The coal tar and distillate light oil composite groups are also hazardous as wastes based on their benzene concentrations (Table 36 and 37). These materials are hazardous if they are to be disposed, but do not have any restrictions if they are used as fuels.

For most of the semivolatile organic compounds in the tars, oils, and hydrocarbon liquids, the WRI and Pace analytical detection limits were much higher Lan the TCLP action levels because of the sample dilutions that were required. Very few of the oily samples were analyzed by Pace and WRI for the regulated semivolatile organic compounds. WRI did roport $8.5 \mathrm{ppm}$ pyridine in the tank cleanout material. The TCLP action lovel for pyridine is $5.0 \mathrm{mg} / \mathrm{L}$. Data from WRI's analyses of the materials in the tar, oil, and hydrocarbon liquid stream for the regulated volatile and semivolatile organic compounds can be found in Appendix E, along with the limited semivolatile data that were reported by Pace.

Results from Metals Analysis of the Tars, Oils, and Hydrocarbon Liquids

After some experimentation, the method that was selected for metals analysis of the oily materials was sample preparation by combustion using bomb calorimetry followed by atomic absorption and inductively coupled plasma spectrometry. SVL Analytical could not analyze most of the tars, oils, and hydrocarbon liquids without raising their detection limits above the TCLP action levels, and they do not perform the ASTM oxygen bomb combustion method. As a result, most of the metals data for the materials in the tar, oil, and hydrocarbon liquid stream were generated by WRI only. WRI metals data for the individual and composite samples in this product stream are listed in Table 38. Many of the metal concentrations listed in Table 38 exceed their TCLP regulatory values. It should be noted that, even with a dilution factor of 20 applied, the concentrations of lead in the tar sand heavy oil and heavy oil composite samples exceed the regulatory value of $5.0 \mathrm{mg} / \mathrm{L}$. The data given in Table 38 will be used in determining proper disposal means for the oily materials. Copies of the data report forms received for WRI metal analyses of the tars, oils, and hydrocarbon liquids are included in Appendix E. 
Table 38. TCLP Regulated Motal Concentrations in the North Site Tar, Oil, and Hydrocarbon Liquid Stream, ppm

\begin{tabular}{|c|c|c|c|c|c|c|c|c|}
\hline $\begin{array}{l}\text { Composite/ } \\
\text { Individual } \\
\text { Sample }\end{array}$ & $\stackrel{\text { A }}{(B .0)^{*}}$ & $\underset{(100)}{\mathrm{Ba}}$ & $\begin{array}{c}\text { Cd } \\
(1.0)\end{array}$ & $\begin{array}{c}C_{r} \\
(\overline{b .0})\end{array}$ & $\begin{array}{c}\mathrm{Pb} \\
(\mathbf{6 . 0})\end{array}$ & $\begin{array}{c}\mathrm{H}_{8} \\
(0.2)\end{array}$ & $\begin{array}{l}80 \\
(1.0)\end{array}$ & A. \\
\hline Shale Oil-1 & 8.97 & $<0.1$ & 0.10 & 0.28 & 4.62 & 0.86 & 1.26 & $<0.1$ \\
\hline Shale Oil-2 & 6.12 & 0.18 & $<0.1$ & 0.14 & 4.16 & 0.21 & $<1.0$ & $<0.1$ \\
\hline Shale Oil-s & 14.1 & $<0.1$ & $<0.1$ & 0.18 & 1.08 & 0.10 & $<1.0$ & $<0.1$ \\
\hline $\begin{array}{l}\text { Shale Oil } \\
\text { Divtillatea }\end{array}$ & $<2.0$ & 0.08 & 0.28 & 0.80 & 0.48 & 0.08 & $<1.0$ & $<0.1$ \\
\hline $\begin{array}{l}\text { Tar Band } \\
\text { Heavy Oil }\end{array}$ & 4.16 & 6.74 & 0.79 & 2.24 & 174 & 0.07 & $<1.0$ & $<0.1$ \\
\hline $\begin{array}{l}\text { Heavy Oil } \\
\text { Plus Coal }\end{array}$ & 2.98 & 22.3 & 0.68 & 11.8 & 14.4 & 0.03 & $<1.0$ & 0.28 \\
\hline $\begin{array}{l}\text { Dirty Oil a } \\
\text { Sludge }\end{array}$ & 5.16 & 11.0 & 0.82 & 0.97 & 72.7 & $<0.02$ & $<0.6$ & $<0.1$ \\
\hline Coal Tar & 2.87 & 61.1 & 0.85 & $' 12.4$ & .6 .60 & 0.64 & 2.86 & 0.60 \\
\hline Heavy Oil & 24.8 & 68.7 & 0.76 & 18.7 & 121 & 0.14 & 1.76 & 1.48 \\
\hline Heavy Fual Oil & $<2.0$ & 0.14 & 0.08 & 0.14 & 0.41 & $<0.02$ & $<1.0$ & $<0.1$ \\
\hline Heavy Crudo Oil & 6.60 & $<0.1$ & $<0.1$ & 0.18 & 0.68 & $<0.02$ & $<1.0$ & $<0.1$ \\
\hline Tank Bottom & 22.2 & .224 & 0.26 & 3.42 & 81.0 & 0.32 & $<1.0$ & 0.69 \\
\hline Tank Watar & 2.32 & 0.12 & $<0.08$ & 0.12 & $<0.6$ & $<0.002$ & 0.86 & $<0.08$ \\
\hline Tank Oil & $<2.0$ & 8.04 & $<0.1$ & 0.98 & $<0.5$ & 0.10 & $<1.0$ & $<0.1$ \\
\hline $\begin{array}{l}\text { Distillate } \\
\text { Light Oil }\end{array}$ & $<2.0$ & $<0.1$ & $<0.1$ & 8.02 & $<0.6$ & 0.18 & $<1.0$ & $<0.1$ \\
\hline Tank Cleanout & 8.86 & $<0.1$ & $<0.1$ & $<0.1$ & $<0.4$ & $<0.02$ & 2.28 & $<0.1$ \\
\hline $\begin{array}{l}\text { Tank Cleanout } \\
\text { Oil }\end{array}$ & 8.42 & 11.8 & 2.16 & 4.68 & 12.8 & 0.40 & 11.1 & 0.59 \\
\hline $\begin{array}{l}\text { Oily Material } \\
\text { Plus Water }\end{array}$ & $<2.0$ & 1.12 & $<0.1$ & 0.52 & $<0.6$ & $<0.02$ & $<0.5$ & $<0.1$ \\
\hline $\begin{array}{l}\text { Tank Bottom } \\
\text { Heavy Oil }\end{array}$ & 42.9 & 11.4 & 2.06 & $\mathbf{6 . 6 2}$ & 19.1 & 0.24 & 1.02 & 0.61 \\
\hline
\end{tabular}

- The value given in parentheses is the regulatory level in mall for each analyte. 
Dilutions of the tank cleanout and tank cleanout oil materials resulted in extremely high detection limits for analyses of their volatile organic compounds. As a result, no useful volatile data were obtained for these materials. However, metals date for the tank eleanout and tank cleanout oil were determined and are listed in Table 38. Both of these materials contain concentrations of the TCLP regulated motal above thoir action levels.

As mentioned above, many of the materials in the tar, oil, and hydrocarbon liquid stream were not analyeed by SVL Analytical, and very little useful motals data were received from the CLP laboratory for the oily materials because of their high detection limits. The metale data received from SVL for the dirty oil and sludge composite sample, conl tar composite sample, and tank cleanout oil composite sample are listed in Table 39, along with WRI data for the composite samples. For the most part, the metal concentrations determined by WRI and SVI for the composite samples agree. However, there are some discrepancies, such as for the concentration of barium in the dirty oil and sludge, the concentrations of chromium and silver in the coal tar, and the concentrations of arsenic, barium, and solenium in the tank cleanout oil. A concentration of arsenic at $107 \mathrm{ppm}$, which was detected by SVL in the tank cleanout oil, makes this material hazardous, even with application of a dilution factor of 20.

Table 89. Metal Concentrations in the Dirty OLl and Sludge, Coal Tar, and Tank Cleanout Oll Componite Samples Determined by SVL Analytical' and WRI, ppm

\begin{tabular}{lcccccccc}
\hline $\begin{array}{l}\text { Composite/ } \\
\text { Individual }\end{array}$ & $\mathrm{As}_{\mathrm{s}}$ & $\mathbf{B a}$ & $\mathrm{Cd}$ & $\mathrm{Cr}$ & $\mathrm{Pb}$ & $\mathrm{Hg}_{\mathrm{g}}$ & $\mathrm{Se}$ & $\mathrm{Ag}$ \\
Sample & $(5.0)^{\mathrm{b}}$ & $(100)$ & $(1.0)$ & $(5.0)$ & $(5.0)$ & $(0.2)$ & $(1.0)$ & $(5.0)$
\end{tabular}

Dirty Oil \& Sludge

$\begin{array}{lllllllll}\text { WRI } & 6.16 & 11.0 & 0.82 & 0.97 & 72.7 & <0.02 & <0.5 & <0.1 \\ \text { SVI } & <8.0 & 1.18 & <0.4 & 0.74 & 76.7 & <0.1 & <8.0 & <0.4\end{array}$

Coal Tar

$\begin{array}{lllllllll}\text { WRI } & 2.37 & 61.1 & 0.85 & 12.4 & 5.60 & 0.54 & 2.85 & 0.60 \\ \text { SVI } & <8.0 & 64.2 & 0.72 & 6.4 & <8.0 & 0.57 & <8.0 & 1.12\end{array}$

Tank Cleanout Oil

$\begin{array}{lllllllll}\text { WRI } & 3.42 & 11.3 & 2.15 & 4.66 & 12.8 & 0.40 & 11.1 & 0.59 \\ \text { SVL } & 107 & 35.7 & 1.65 & 5.26 & 11.5 & 0.30 & 22.7 & <0.4\end{array}$

- SVL Analytical is the inorganic CLP laboratory that was used in phase I to verify WRI's analytical results.

b The value given in parentheses is the regulatory lovel in mg/L for each analyte. 
The higher detection limite, which were roported by SVL, limit comparison of the data in Table 89. In addition to WRI motals data, the SVL motale data will also be used to provide information for selecting proper disposal options for the materials in this product otream. All motale date, which were genorated by SVL for the tar, oil, and hydrocarbon liquid stream, aro included in Appendix $\mathbf{E}$.

Flach Point Charecterization of the Shale Oil Diatillate Samples and the Distillate Lisht Oil Composite Sample

Samples of the three materiale comprising the shale oil distillate composite group and a composite sample of the distillate light oil (Table 8) were analyzed by WRI and Pace for thoir flash point. The flash point values for the eamples are listed in Table 40. As epecified in 40 CFR 261.21 (1992), aste exhibits the characteristic of ignitability if it has a nash point less than $140^{\circ} \mathrm{F}\left(60^{\circ} \mathrm{C}\right)$. Based on this criterion, the oil shale distillates and the distillate light oil composite sample exhibit the hazardous characteristic of ignitability. For shale oil distillate samples 614 and 615, WRI did not report a flash point value that classifies the materials as hazardous based on ignitability; however, for these samples, Pace did report values that are less than $140^{\circ} \mathrm{F}$. As a result, the samples will be considered hazardous based on ignitability.

Table 40. Flash Point Values for the Shale O1I Ditillete Samples and the Dintillnte Light Oll Componite Eample

Sample $\quad$ Flash Point, $F \quad$ Regulatory Value, $F$
Shale Oil Distillate-614
WRI
Pace*

140

120

$<140$

$<140$

Shale Oil Distillate-615

WRI

168

184

$<140$

Pace

128

$<140$

$<140$
$<82$

118
$<140$

$<140$

- Pace Laboratory is the organic CLP laboratory that was used in phase I to verify WRI's analytical results.

b WRI reported that the sample contained too much water for nash point determination. 


\section{Btu Charactorization of the Heavy Fuel Oils}

Individual samples of the materials comprising the heavy fuel oil composite group (Table 8) were analyzed by WRI for their Btu content to provide information on their usefulness as fuels. Btu values for the aix materials ranged from 16,752 to $17,543 \mathrm{Btu} / \mathrm{lb}$, with an average value of $17,311 \mathrm{Btu} / \mathrm{bb}$.

Hazand Classification of the Tars, Oils, and Hydrocarbon Liquids

The hazard classification for each of the materials in the tar, oil, and hydrocarbon liquid stream is given in Table 41 , along with the failing characteristic. All of the composite group in the tar, oil, and hydrocarbon liquid stream, except the oil pitch and tank bottom hoavy oil solid aro hazardous.

Table 41. Hazard Claselfication for the Tars, Olls, and Hydrocarbon Hquids

Composite Group Hazard Classification $\quad \begin{gathered}\text { Failing Characteristic/ } \\ \text { Analyto }\end{gathered}$

Tank Bottom Heavy Oil Solid

Oil Pitch

Shale Oil-1

Shale Oil-2

Shale Oil-3

Shale Oil Distillates

Tar Sand Heavy Oil

Heavy Oil Plus Coal

Dirty Oil \& Sludge

Coal Tar

Heavy Oil

Heavy Fuel Oil

Heavy Crude Oil

Tank Bottom

Tank Water

Tank Oil

Distillate

Light Oil

Tank Cleanout

Tank Cleanout Oil

Oily Material

Plus Water

Tank Bottom

Heavy Oil
Nonhazardous

Nonhazardous

Hezardous

Hazardous

Hazardous

Hezardous

Hazardous

Hazardous

Hazardous

Hazardous

Hazardous

Hazardous

Hezardous

Hezardous

Hazardous

Hezardous

Hazardous

Hazardous

Hazardous

Hazardous

Hezardous
Toxicity/Benzene

Toxicity/Benzene

Toxicity/Benzene

Toxicity/Benzene

Ignitability/Flash Point .

Toxicity/Benzene, Lead

Toxicity/Benzene

Toxicity/Benzene

Toxicity/Benzene

Toxicity/Benzene,

Trichloroethene, Lead

Toxicity/Benzene

Toxicity/Benzene

Toxicity/Benzene

Toxicity/Trichloroethene

Toxicity/Trichloroethene,

Benzene

Toxicity/Benzene

Ignitability/Flash Point

Toxicity

Toxicity/Arsenic

Toxicity/Benzene

Toxicity 
As discussed, the oil pitch and tank bottom heavy oil solid composite samples were characterized for toxicity by TCLP extraction. The TCLP extracts of both materials contained none of the TCLP regulated analytes in concentrations above their TCLP regulatory levels, and as a result, these composite groups are nonhazardous based on toxicity.

As shown in Table 39, SVL Analytical detected $107 \mathrm{ppm}$ of arsenic in the tank cleanout oil composite sample. Dividing $107 \mathrm{ppm}$ by a dilution factor of 20 , which is most likely high for this material, gives a value of $5.3 \mathrm{ppm}$. The regulatory level for arsenic is $5.0 \mathrm{mg} / \mathrm{L}$, and as a result, the tank cleanout oil is hazardous based on the SVL data. This value is questionable since WRI reported only $3.42 \mathrm{ppm}$ arsenic in the composite sample; however, to save the costs of additional sampling and analyses, a conservative approach was taken, and the material is considered to be hazardous.

For disposal, the tank cleanout material will also be considered hazardous. As mentioned, this material contains $8.5 \mathrm{ppm}$ pyridine, and as shown in Table 38, the tank cleanout also contains $2.2 \mathrm{ppm}$ selenium. However, these concentrations should be divided by a dilution factor for toxicity characteristic evaluation. In addition, volatile and semivolatile organic analyses of this material gave many analytical detection limits that were above the regulatory levels. As a result, to correctly classify this material as hazardous or nonhazardous, TCLP extraction is required. However, because there is only one 30-gallon container of this material, it is more cost effective to dispose of it as a hazardous waste than to pay for the extraction and analyses for TCLP characterization.

For disposal, the tank bottom heavy oil will also be classified has hazardous. As shown in Tables 36 and 38, this material contains several of the TCLP regulated analytes at concentrations above the TCLP action levels. However, once again these concentrations should be divided by a dilution factor for toxicity characteristic evaluation. In addition, semivolatile organic analyses of this material gave many analytical detection limits that were above the regulatory lovels. As a result, to correctly classify this material as kiazardous or nonhazardous, TCLP extraction is required. Once again, it is believed to be more cost effective for the project to dispose of the materials in this composite group as hazardous wastes, rather that to pay for the extraction and analyses for TCLP characterization.

\section{Analysis of Tars, Oils, and Hydrocarbon Liquids QAMC Samples}

Metals, semivolatile organic, and volatile organic field trip blanks were taken to the field during sampling of the tank eleanout, tank cleanout oil, oily material plus water, dirty oil and sludge, and coal tar materials. These blanks were analyzed during analysis of the oily materials to check for any contamination aue to the field environment, including sample storage and transportation. The blanks were 
analyzed by WRI, and none of the TCLP regulated analytes were detected at concentrations above the analytical detection limits.

Two coal tar composite samples were prepared in phase I. The first of these was split, and the coal tar composite and its split wore submitted to WRI and the CLP laboratories as blind samples for analysis of benzene and the regulated metals. Table 42 shows the data from these analyses. Copies of the date report forms for these samples are also included with the tars, oils, and hydrocarbon liquids data in Appendix E. There is good agreement between the metal values listed in Table 42, both between WRI and SVL values and between values determined by the two laboratories for the splits. Unfortunately, for arsenic, lead, and selenium, SVL could only report less than 8 ppm; however, the values, which were determined by WRI for these elements, were less than 8 ppm as reported by SVL. Silver is the only element for which the values reported by the laboratories do not agree. For the hazard classifications, this is not a problem. In the oily materials, silver is not an element of concern because most of the concentrations of silver that were detected in the samples are less than 0.1 ppm.

For benzene analysis of the coal tar and its split (Table 42), greater than values were reported by both WRI and Pace. In all cases, the greater than values are much higher than the regulatory value of $0.5 \mathrm{mg} / \mathrm{L}$, and even with a dilution factor of 20 applied, all result in a hazard classification for the coal tar material.

Table 42. QA/QC Data from Analyees of a Coal Tar Composite and Its Blind Split, ppm *

\begin{tabular}{lcccccc}
\hline \multirow{2}{*}{ TCLP Analyte } & \multicolumn{2}{c}{ Coal Tar Composite } & & \multicolumn{2}{c}{ Blind Split } \\
\cline { 2 - 3 } & WRI & CLP & & WRI & CLP \\
\hline Arsenic & 1.90 & $<8.0$ & 1.97 & $<8.0$ \\
Barium & 57.4 & 64.2 & 61.1 & 67.4 \\
Cadmium & 0.64 & 0.72 & 0.85 & 0.59 \\
Chromium & 5.16 & 6.42 & 6.77 & 4.41 \\
Lend & 5.18 & $<8.0$ & 6.60 & $<8.0$ \\
Mereury & 0.48 & 0.57 & 0.54 & $<0.1$ \\
Selenium & 2.07 & $<8.0$ & 2.35 & $<8.0$ \\
Silver & 0.60 & 1.12 & $<0.1$ & 0.94 \\
Benzene & 226 & $>1,900$ & $>1,600$ & $>1,300$ \\
& & & & &
\end{tabular}

- These values may differ from those listed in Tables $36,37,38$, and 39 because two coal tar composites were prepared. The values reported in Tables 36, 87, 38, and 39 are the highest concentrations that were determined from analysis of the two composites. 


\section{Analysis of the North Site Chomicals and Unknown Materials}

The unknown materials and chemicals listed in Tables 9 and 10 were analyzed by WRI using screening methods to provide information on their composition and identity. The only material that was not analyzed is the chlorinated solvent, which was deemed hazardous based on knowledge that it is indeed chlorinated solvent. Initial screening showed the artic $75 / 90$ material to be diesel fuel. Screening also showed the pellets composite to contain no organic compounds that are amenable to gas chromatographic analysis. As a result, the pellet composite was extracted by TCLP for the regulated metals. Results for this extraction, which were discussed in the section of this report on results from TCLP extraction of composite and individual samples (see Tables 17 and 18), along with the information from the organic screen, show that the pellets are not hazardous. The identity of the chemicals, monoethanolamine, which has a $\mathrm{pH}$ of 12.6 , and tretolite, were verified, and these materials were deemed hazardous. Also the material labeled unknown material, which is a liquid solvent, was determined to be hazardous based on its concentrations of benzene at 4,200 ppm and lead at 13 ppm.

The remaining materials listed in Tables 9 and 10 were determined to contain nrimarily inorganic constituents and were further analyzed to determine the cancentrations of their inorganic components. These are listed in Table 43. Based on the data given in this table and previous analyses, the identity of the material labeled as soda ash was confirmed.

To classify the remaining materials listed in Table 43 as hazardous or nonhazardous and to save the time and expense of TCLP extractions, the materials were analyzed directly for the TCLP regulated metals and semivolatile and volatile organic compounds. The concentrations of the TCLP regulated metals that were determined to be prasent in the unknown materials and chemicals are listed in Table 44. As shewn, none of the metals exceed the TCLP regulatory levels. In addition, none of the TCLP regulated semivolatile organic compounds were detected in these materials at concentrations above their analytical detection limits, and only very low concentrations (0.05-2.3 ppm) of methyl ethyl ketone were detected in the unknown liquid, caustic soda, boiler water treatment, and dry water treatment-1. The regulatory level for methyl ethyl ketone is $200 \mathrm{mg} / \mathrm{L}$. This is the only volatile organic compound that was detected above the analytical detection limits in any of the unknown materials and chemicals listed in Tables 43 and 44 . As a result, these materials can be classified as nonhazardous. The data report forms for analysis of the chemicals and untnown materials can be found in Appendix $\mathbf{E}$.

Metals, semivolatile organic, and volatile organic field trip blanks were taken to the field during sampling of the North Site chemicals and unknown materials. These blanks were analyzed by WRI to check for any contamination of the materials due to the field environment, including sample storage and transportation. None of the TCLP regulated analytes were detected at concentrations above their analytical detection limits in any of the blanks. Results from analysis of the field trip blanks are included with the unkrown material and chemical data in Appendix E. 
Table 43. Inorganic Characterization of the North Site Chemicals and Unknown Materials

\begin{tabular}{|c|c|c|}
\hline Composito & Metals & Anions \\
\hline $\begin{array}{l}\text { Dry Water Treatment-1 } \\
\text { (Solid) } \\
\text { pH = } 10.2 \\
\text { (17:1 waterisolid) }\end{array}$ & $\begin{array}{l}46.6 \% \mathrm{Na} \\
489 \mathrm{ppm} \mathrm{K} \\
251 \mathrm{ppm} \mathrm{Co}\end{array}$ & $\begin{array}{l}160,000 \text { ppm Sulfate } \\
\text { 1,400 ppm Chloride } \\
1,300 \text { ppm Nitrate as N }\end{array}$ \\
\hline $\begin{array}{l}\text { Dry Water Treatment-2 } \\
\text { (Liquid) } \\
\mathrm{pH}=6.5\end{array}$ & $\begin{array}{l}2.7 \% \mathrm{Na} \\
128 \text { ppm } \mathrm{K}\end{array}$ & $\begin{array}{l}12,400 \text { ppm Sulfate } \\
2,700 \text { ppm Orthophosphate as } P \\
350 \text { ppm Chloride }\end{array}$ \\
\hline $\begin{array}{l}\text { Caustic Soda } \\
\text { (Liquid-labeled 50\% } \\
\text { Aqueous } \mathrm{NaOH} \text { ) pH = } 7.7\end{array}$ & $6.64 \% \mathrm{Na}$ & $\begin{array}{l}\text { <10 ppm Mineral Carbon } \\
13 \text { ppm Sulfate } \\
\text { (Anion screen can not } \\
\text { detect hydroxide. Absence } \\
\text { of other major anions } \\
\text { indicates presence of } \\
\text { hydroxide. }\end{array}$ \\
\hline $\begin{array}{l}\text { Boiler Water Treatment } \\
\text { (Liquid) } \\
\text { pH }=12.1\end{array}$ & $\begin{array}{l}3.14 \% \mathrm{Na} \\
247 \text { ppm K } \\
93 \text { ppm Ca. }\end{array}$ & $\begin{array}{l}3,600 \text { ppm Sulfate } \\
930 \text { ppm Chloride } \\
900 \text { ppm Ortho- } \\
\text { Phosphate as P } \\
289 \text { ppm Mineral Carbon }\end{array}$ \\
\hline $\begin{array}{l}\text { Soda Ash } \\
\text { (Solid) } \\
\text { pH }=10.7 \\
\text { (1:1 waterasolid) }\end{array}$ & $\begin{array}{l}46.7 \% \mathrm{Na} \\
96.5 \mathrm{ppm} \mathrm{Ca}\end{array}$ & 11\% Mineral Carbon \\
\hline $\begin{array}{l}\text { Unknown Liquid } \\
\text { (Water Soluble) } \\
\mathrm{pH}=6.3\end{array}$ & $\begin{array}{l}3.19 \% \mathrm{Na} \\
3,554 \mathrm{ppm} \mathrm{K} \\
3,177 \mathrm{ppm} \mathrm{B} \\
471 \mathrm{ppm} \mathrm{Ni} \\
337 \mathrm{ppm} \mathrm{Mg}\end{array}$ & $\begin{array}{l}54,000 \text { ppm Chloride } \\
12,000 \text { ppm Sulfate } \\
21 \text { ppm Nitrate as N }\end{array}$ \\
\hline $\begin{array}{l}\text { SAI Comp Material- } \\
\text { Liquid } \\
\mathrm{pH}=\mathbf{8 . 1}\end{array}$ & $\begin{array}{l}4.42 \% \mathrm{Na} \\
198 \mathrm{ppm} \mathrm{K} \\
44.8 \mathrm{ppm} \mathrm{Si}\end{array}$ & $\begin{array}{l}450 \text { ppm Nitrate as } N \\
190 \text { ppm Chloride } \\
70 \text { ppm Sulfate }\end{array}$ \\
\hline $\begin{array}{l}\text { SAI Comp Material- } \\
\text { Solid } \\
\text { pH = } 7.5 \\
\text { (5:1 wateresolid) }\end{array}$ & $\begin{array}{l}22.1 \% \mathrm{Na} \\
2,270 \mathrm{ppm} \mathrm{Ca} \\
375 \mathrm{ppm} \mathrm{Si}\end{array}$ & $\begin{array}{l}360,000 \text { ppm Sulfate } \\
\text { 3,10 ppm Chloride } \\
\text { 2,600 ppm Nitrate as N }\end{array}$ \\
\hline
\end{tabular}


Table 44. TC:.-P Regulated Metal Concentrations in the North Site Unknown Materials and Chemicale, Ppm

\begin{tabular}{|c|c|c|c|c|c|c|c|c|}
\hline $\begin{array}{l}\text { Composite/ } \\
\text { Individual } \\
\text { Sample }\end{array}$ & $\begin{array}{c}\text { As } \\
(5.0)^{a}\end{array}$ & $\begin{array}{c}\mathrm{Ba} \\
(100)\end{array}$ & $\underset{(1.0)}{C d}$ & $\underset{(5.0)}{\mathbf{C r}}$ & $\begin{array}{c}\mathrm{Pb} \\
(\bar{b} .0)\end{array}$ & $\begin{array}{l}\mathrm{Hg} \\
(0.2)\end{array}$ & $\begin{array}{l}\text { Se } \\
(1.0)\end{array}$ & $\begin{array}{c}\mathrm{Ag} \\
(5.0)\end{array}$ \\
\hline $\begin{array}{l}\text { Dry Water } \\
\text { Trentment-1 }\end{array}$ & $<0.6$ & $<0.7$ & $<0.7$ & $<0.5$ & $<1.5$ & $<0.02$ & $<0.6$ & $<0.6$ \\
\hline $\begin{array}{l}\text { Dry Water } \\
\text { Treatment-2 }\end{array}$ & 3.21 & 0.285 & 0.023 & 0.419 & $<0.5$ & $<0.002$ & $<0.1$ & $<0.1$ \\
\hline Caustic Soda & $<1.0$ & $<0.1$ & $<0.1$ & 0.10 & $<1.0$ & 0.093 & $<1.0$ & $<1.0$ \\
\hline $\begin{array}{l}\text { Boiler Water } \\
\text { Treatment }\end{array}$ & $<1.0$ & $<0.1$ & $<0.1$ & 0.31 & $<5.0$ & $<0.002$ & $<1.0$ & $<0.1$ \\
\hline Unknown Liquid & $<1.0$ & 0.24 & $<0.1$ & 0.20 & $<1.0$ & $<0.002$ & $<1.0$ & $<1 . j$ \\
\hline $\begin{array}{l}\text { SAI Comp Material. } \\
\text { Liquid }\end{array}$ & $<0.1$ & 0.083 & 0.143 & 2.78 & $<0.5$ & $<0.002$ & $<0.1$ & $<0.1$ \\
\hline $\begin{array}{l}\text { SAI Comp Material- } \\
\text { Solid }\end{array}$ & $<0.6$ & $<0.6$ & $<0.6$ & 2.04 & $<1.4$ & $<0.02$ & $<0.6$ & $<0.6$ \\
\hline
\end{tabular}

- The value given in parentheses is the regulatory level in mgl for cach analyte.

Results from Analysis of the Fleld Equipment Blanks

Two sets of field equipment blanks, scoop blanks and coliwasa blanks, were analyzed by WRI for the regulated metals, semivolatile organic compounds, and volatile organic compounds to show any contamination of the North Site samples contributed by the sampling equipment. As discussed, disposable glass coliwasas and plastic scoops were primarily used for sampling the North Site materials. In both the scoop and coliwasa field equipment blanks, all concentrations of the TCLP regulated metals and semivolatile organic compounds were reported below analytical detection limits. The same was true for the concentrations of the regulated volatile organic compounds, except a concentration of methyl ethyl ketone at $0.02 \mathrm{mg} / \mathrm{L}$ was detected in the coliwasa equipment blank. The regulatory level for this compound is $200 \mathrm{mg} / \mathrm{L}$. Besed on these results, it appears that the sampling equipment did not contribute any contamination to tha North Site samples that affected the sample data. Copies of the data report forms for analyses of the field equipment blanks can be found in Appendix $\mathbf{E}$. 


\section{CONCLUSIONS}

The objective of phase I of this cleanup project was to define the North Site product streams requiring disposel or use. Information on the identity and composition of the materials in each of the product streams, as well as their hazard classification, has been obtained. Sixty-nine composite or individual samples were characterizod. Forty-one of these are nonhazandous, and 28 are hazardous based on the characteristic of toxicity. Two of the composite groups that fail toxicity also fail the characteristic of ignitability. Most of the composite groups that were determined to be hazardous are oily materials that contain high concentrations of benzene. Hazard classification information for the North Site composite groups is summarized in Table 45. The information presented in this report represents the bulk of the North Site materials requiring characterization. However, as the project proceeds, there may be additional materials that require hazard testing. Depending on the nature of these materials, they will be characterized in the same manner used for the materials described in this report. Information obtained in phase I will now be used in phases II and III of the North Site cleanup project. These phases, which involve disposal or use of the North Site materials, can now begin. 
Table 45. Hazard Classification of the North Site Composite Groups

\begin{tabular}{|c|c|c|c|}
\hline $\begin{array}{l}\text { Product Stream/ } \\
\text { Composite Group }\end{array}$ & $\begin{array}{l}\text { Containers } \\
\text { - Represented }\end{array}$ & $\begin{array}{c}\text { Hazard } \\
\text { Classification }\end{array}$ & Comments \\
\hline \multicolumn{4}{|c|}{ Unprocessed Tar Sands } \\
\hline Tar Send & $\begin{array}{l}14-48,50-54 \\
66-63,65,221- \\
223,226-240 \\
862-885,1159 \\
1160\end{array}$ & Nonhazardous & $\begin{array}{l}\text { Passes TCLP } \\
\text { Extraction } \\
\text { 1,689 Btu/lb }\end{array}$ \\
\hline Tar Sand Sludge & 49 & Nonhazardous & $\begin{array}{l}\text { Passes TCLP } \\
\text { Extraction } \\
7,885 \text { Btu/lb }\end{array}$ \\
\hline \multicolumn{4}{|l|}{ Unprocessed Coals } \\
\hline $\begin{array}{l}\text { Unprocessed } \\
\text { Western Coal }\end{array}$ & $\begin{array}{l}83-94,97-114, \\
116,117,119 \\
138,213-220, \\
372,653-560, \\
567-569,578, \\
574,812-814, \\
939-942,983, \\
988,990,1070, \\
1071,1161-1166\end{array}$ & Nonhazardous & $\begin{array}{l}\text { Passes TCI.P } \\
\text { Extraction } \\
9,772 \text { Btu/lb }\end{array}$ \\
\hline $\begin{array}{l}\text { Unprocessed } \\
\text { Eastern Coal }\end{array}$ & $\begin{array}{l}1-4,85,96 \\
115,201-212 \\
810,811,1212\end{array}$ & Nonhezardous & $\begin{array}{l}\text { Passes TCLP } \\
\text { Extraction } \\
\text { 10,880 Btu/lb }\end{array}$ \\
\hline \multicolumn{4}{|l|}{ Raw Oil Shales } \\
\hline $\begin{array}{l}\text { Rav Western } \\
\text { Oil Shale }\end{array}$ & $\begin{array}{l}139-161,241- \\
277,374-406 \\
409-421,424 \\
434,436-473, \\
547-549,815,816\end{array}$ & Nonhazardous & $\begin{array}{l}\text { Passes TCLP } \\
\text { Dxtraction } \\
\text { 2,394 Btu }\end{array}$ \\
\hline $\begin{array}{l}\text { Rav Eastern } \\
\text { Oil Shale }\end{array}$ & $\begin{array}{l}162-180,182 \\
183,185-200 \\
337-343,354 \\
362,407,408 \\
855,856,1167\end{array}$ & Nonhazardous & $\begin{array}{l}\text { Passes TCLP } \\
\text { Extraction } \\
2,928 \text { Btu }\end{array}$ \\
\hline Raw Shale Pile & $\begin{array}{l}1260,1262 . \\
1264\end{array}$ & Nonhazandous & $\begin{array}{l}\text { Passes TCLP } \\
\text { Extraction } \\
\text { 2,138 Btu }\end{array}$ \\
\hline
\end{tabular}


Table 45. Hazard Classification of the North Site Composite Groups (continued)

\begin{tabular}{|c|c|c|}
\hline $\begin{array}{l}\text { Product Streem/ } \\
\text { Composite Group }\end{array}$ & $\begin{array}{l}\text { Containers } \\
\text { Represented }\end{array}$ & $\begin{array}{c}\text { Hazard } \\
\text { Classification }\end{array}$ \\
\hline
\end{tabular}

Spent Oil Shale, Processed Tar Sand, Activated Chareoal

\begin{tabular}{|c|c|c|c|}
\hline Spent Oil Shale-1 & $\begin{array}{l}328-332,363 . \\
367,541 \cdot \\
546,818\end{array}$ & Nonhazardous & $\begin{array}{l}\text { Passes TCLP } \\
\text { Extraction }\end{array}$ \\
\hline Spent Oil Shale-2 & 1080,1081 & Noshazardous & $\begin{array}{l}\text { Passes TCLP } \\
\text { Extraction }\end{array}$ \\
\hline $\begin{array}{l}\text { Spent Oil Shale } \\
\text { Pile }\end{array}$ & 1259,1261 & Nonhazardous & $\begin{array}{l}\text { Passes TCLP } \\
\text { Extraction }\end{array}$ \\
\hline Spent Tar Sand & 368-371, 373 & Nonhazardous & $\begin{array}{l}\text { Passes TCLP } \\
\text { Extrection }\end{array}$ \\
\hline Activated Charcoal & $\begin{array}{l}684-702,826 \\
838,840-852 \\
1170,1226,1227\end{array}$ & Nonhezardous & $\begin{array}{l}\text { Passes TCLP } \\
\text { Extraction }\end{array}$ \\
\hline $\begin{array}{l}\text { Unused Activated } \\
\text { Charcoal }\end{array}$ & 859,860 & Nonhazardous & $\begin{array}{l}\text { Pasces TCLP } \\
\text { Extraction }\end{array}$ \\
\hline MG Fines, Char & $\begin{array}{l}\text { 1204-1211, } \\
\text { 1213-1219, } \\
\text { 1221-1225, } 1257\end{array}$ & Nonhazardous & $\begin{array}{l}\text { Passes TCLP } \\
\text { Extraction }\end{array}$ \\
\hline \multicolumn{4}{|c|}{ Miscellaneous Materials } \\
\hline Oily Insulation & 948, 949 & Nonhazardous & $\begin{array}{l}\text { Passes TCLP } \\
\text { Extraction }\end{array}$ \\
\hline Tank Bottom Liner & $820,821,823$ & Nonhazandous & $\begin{array}{l}\text { Pareas TCLP } \\
\text { Extraction }\end{array}$ \\
\hline $\begin{array}{l}\text { Evaporation Tank } \\
\text { Bottom Dirt }\end{array}$ & $933,1244,1245$ & Nonhazardous & $\begin{array}{l}\text { Passes TCLP } \\
\text { Extraction }\end{array}$ \\
\hline Oily Dirt & 645-655, 999 & Nonhazardous & $\begin{array}{l}\text { Passes TCLP } \\
\text { Extraction }\end{array}$ \\
\hline Sulfur & 950 & Nonhazardous & $\begin{array}{l}\text { Pasoes TCLP } \\
\text { Extraction }\end{array}$ \\
\hline Crushed KC Rock & 1121 & Nonhazardous & $\begin{array}{l}\text { Passes TCLP } \\
\text { Extraction }\end{array}$ \\
\hline Fly Ash & 891-912 & Nonhazardous & $\begin{array}{l}\text { Passes TCLP } \\
\text { Extraction }\end{array}$ \\
\hline
\end{tabular}


Table 45. Hazard Classification of the North Site Composite Groups (continued)

\begin{tabular}{|c|c|c|c|}
\hline $\begin{array}{l}\text { Product Stream/ } \\
\text { Composite Group }\end{array}$ & $\begin{array}{l}\text { Containers } \\
\text { Represented }\end{array}$ & $\begin{array}{c}\text { Hezard } \\
\text { Classification }\end{array}$ & Comments \\
\hline \multicolumn{4}{|l|}{ Watere } \\
\hline Retort Water & $350,1079,1122$ & Nonharandous & $\begin{array}{l}\text { Analyzed for } \\
\text { TCLP regulated } \\
\text { analytes } \\
\text { pH }=9.2\end{array}$ \\
\hline Graham Water & $1113-1120$ & $\begin{array}{l}\text { Nonhazardous } \\
\text { but Radionetive }\end{array}$ & $\begin{array}{l}\text { Analyzed for } \\
\text { TCLP regulated } \\
\text { analytes } \\
\text { pH }=9.1 \\
\text { Contains } \\
\text { Radium } 226\end{array}$ \\
\hline $\begin{array}{l}\text { Tank Cleanout } \\
\text { Water }\end{array}$ & 931,944 & Nonhazardous & $\begin{array}{l}\text { Analyzed for } \\
\text { TCLP regulated } \\
\text { analytes } \\
\text { pH }=\mathbf{9 . 3}\end{array}$ \\
\hline Water Scavenger & $493-495$ & Nonhazardous & $\begin{array}{l}\text { Analyzed for } \\
\text { TCLP regulated } \\
\text { analytes } \\
\text { pH }=2.6\end{array}$ \\
\hline $\begin{array}{l}\text { Water, Coal } \\
\text { Fines, Oil }\end{array}$ & 1198 & Nonhazardous & $\begin{array}{l}\text { Annlyzed for } \\
\text { TCLP regulated } \\
\text { analytes } \\
\text { pH = } 7.9\end{array}$ \\
\hline $\begin{array}{l}\text { Unidentified } \\
\text { UCG Water }\end{array}$ & 1271 & Nonhezardous & $\begin{array}{l}\text { Analyzed for } \\
\text { TCLP regulated } \\
\text { analytes } \\
\text { pH }=8.1\end{array}$ \\
\hline Hoe Crieek Water & 1278 & Nonhazardous & $\begin{array}{l}\text { Analyzed for } \\
\text { TCLP regulated } \\
\text { analytes } \\
\text { pH = } \mathbf{8 . 3}\end{array}$ \\
\hline RM1 Water & 1272 & Nonhazardous & $\begin{array}{l}\text { Analyzed for } \\
\text { TCLP regulated } \\
\text { analytes } \\
\text { pH }=8.3\end{array}$ \\
\hline CROW Water & 1267,1268 & Nonhazandous & $\begin{array}{l}\text { Analyzed for } \\
\text { TCLP regulated } \\
\text { analytes } \\
\text { pH }=6.9\end{array}$ \\
\hline
\end{tabular}


Table 46. Hazard Claseification of the North Site Composite Groups (continued)

\begin{tabular}{|c|c|c|c|}
\hline $\begin{array}{l}\text { Product Stronm/ } \\
\text { Composite Group }\end{array}$ & $\begin{array}{l}\text { Containers } \\
\text { Represented }\end{array}$ & $\begin{array}{c}\text { Hazand } \\
\text { Claseification }\end{array}$ & Comments \\
\hline \multicolumn{4}{|l|}{ Watere (continued) } \\
\hline Tank Bottom Wator & $\begin{array}{l}824,826,889 \\
947\end{array}$ & Hazardous & $\begin{array}{l}\text { Analyzed for } \\
\text { TCLP regulated } \\
\text { analytes-Fails } \\
\text { As \& Se } \\
\text { pH = } 8.9\end{array}$ \\
\hline Sludyy Water & 650 & Hezardous & $\begin{array}{l}\text { Analyzed for } \\
\text { TCLP regulated } \\
\text { analytes-Fails } \\
\text { As, Cd, Cr } \\
\text { pH = 7.1 }\end{array}$ \\
\hline $\begin{array}{l}\text { Treolite } \\
\text { Distillates }\end{array}$ & 618 & Hazardous & $\begin{array}{l}\text { Analyzed for } \\
\text { TCLP regulated } \\
\text { inalytes-Fails } \\
\text { Benzene } \\
\text { pH = } \mathbf{6 . 0}\end{array}$ \\
\hline $\begin{array}{l}\text { Free \& Distilled } \\
\text { Water }\end{array}$ & 1201 & Hazardous & $\begin{array}{l}\text { Analyzed for } \\
\text { TCLP regulated } \\
\text { anelytes-Fails } \\
\text { Se, Cresol, } \\
\text { Benzene } \\
\text { pH }=7.0\end{array}$ \\
\hline \multicolumn{4}{|c|}{ Tars, Oils, and Hydrocarbon Liquius } \\
\hline $\begin{array}{l}\text { Tank Bottom Heavy } \\
\text { Oil Solid }\end{array}$ & $65,643,890$ & Nonhazardous & $\begin{array}{l}\text { Passes TCLP } \\
\text { Extraction }\end{array}$ \\
\hline Oil Pitch & $\begin{array}{l}951-956,975 \\
976,1258\end{array}$ & Nonhazardous & $\begin{array}{l}\text { Passes TCLP } \\
\text { Extraction }\end{array}$ \\
\hline Shale Oil-1 & $\begin{array}{l}279,282,293, \\
294,295,298, \\
299,301,819 \\
320,322\end{array}$ & Hezardous & $\begin{array}{l}\text { Analyred for } \\
\text { TCLP regulated } \\
\text { analytes-Fails } \\
\text { Benzene }\end{array}$ \\
\hline Shale Oil-2 & $844,846-848$ & Hezardous & $\begin{array}{l}\text { Analyzed for } \\
\text { TCLP regulated } \\
\text { analytes-Fails } \\
\text { Benzene }\end{array}$ \\
\hline
\end{tabular}


Table 46. Hazard Claseffication of the North Site Composite Groups (continued)

\begin{tabular}{|c|c|c|c|}
\hline $\begin{array}{l}\text { Product Stream/ } \\
\text { Composite Group }\end{array}$ & $\begin{array}{l}\text { Containers } \\
\text { Represented }\end{array}$ & $\begin{array}{c}\text { Hazard } \\
\text { Clessification }\end{array}$ & Comments \\
\hline \multicolumn{4}{|c|}{ Tare, Oils and Hydrocerbon Liquids (continued) } \\
\hline Shale Oil-3 & $776-784$ & Hazardous & $\begin{array}{l}\text { Analyzed for } \\
\text { TCLP regulated } \\
\text { analytos-Fails } \\
\text { Benzene }\end{array}$ \\
\hline $\begin{array}{l}\text { Shale Oil } \\
\text { Distillatee }\end{array}$ & $614,615,656$ & Hazardous & $\begin{array}{l}\text { Analyzed for } \\
\text { TCLP rogulated } \\
\text { analytes-Fails } \\
\text { Benzone } \\
\text { Fail } \\
\text { Ignitability } \\
\text { Flash pt.=<140 F }\end{array}$ \\
\hline Tar Sand Heavy Oil & $\begin{array}{l}64,498,577 \\
699,1139,1141\end{array}$ & Hazardous & $\begin{array}{l}\text { Analyzed for } \\
\text { TCLP regulated } \\
\text { analytes-Faile } \\
\text { Benzene, Pb }\end{array}$ \\
\hline $\begin{array}{l}\text { Henvy Oil Plus } \\
\text { Coal }\end{array}$ & $\begin{array}{l}474-477,500 \\
602\end{array}$ & Hazardous & $\begin{array}{l}\text { Analyzed for } \\
\text { TCLP regulated } \\
\text { analytee-Fails } \\
\text { Bensene }\end{array}$ \\
\hline $\begin{array}{l}\text { Dirty Oil \& } \\
\text { Sludge }\end{array}$ & $\begin{array}{l}785,794,795 \\
858\end{array}$ & Hazardous & $\begin{array}{l}\text { Analyzed for } \\
\text { TCLP regulated } \\
\text { analytes-Fails } \\
\text { Benzene }\end{array}$ \\
\hline Coal Tar & $\begin{array}{l}482,959-974 \\
1135-1138\end{array}$ & Hazardous & $\begin{array}{l}\text { Analyzed for } \\
\text { TCLP regulated } \\
\text { analytes-Fails } \\
\text { Benzene }\end{array}$ \\
\hline Heavy Oil & $\begin{array}{l}66,805,489 \\
490,491,987\end{array}$ & Hazardous & $\begin{array}{l}\text { Analyzed for } \\
\text { TCLP regulated } \\
\text { analytes-Fails } \\
\text { Pb, Trichloro- } \\
\text { othene, Benzene }\end{array}$ \\
\hline Heavy Fuel Oil & $\begin{array}{l}6,7,9,10 \\
11,12\end{array}$ & Hazaridous & $\begin{array}{l}\text { Analyzed for } \\
\text { TCLP regulated } \\
\text { analytes-Fails } \\
\text { Benzene } \\
17,311 \text { Btu/lb }\end{array}$ \\
\hline Heavy Crude Oil & $787,792,793$ & Hazardous & $\begin{array}{l}\text { Analyzed for } \\
\text { TCLP regulated } \\
\text { analytes-Fails } \\
\text { Benzene }\end{array}$ \\
\hline
\end{tabular}


Table 46. Hazard Clasuification of the North Site Composite Groups (contlnued)

\begin{tabular}{|c|}
\hline $\begin{array}{l}\text { Product Stroem/ } \\
\text { Composito Group }\end{array}$ \\
\hline
\end{tabular}

Tare, Oils, and Hydrocarbon Liquide (continued)

Tank Bottom

Tank Water

1265

$843,957,858$, 978

Hazardous

Hezerdous

Tank Oil

Distillate

Light Oil

Tank Cleanout

Tank Cleanout Oil

Oily Material

Plus Water

Tank Bottom

Heavy Oil
1199,1200

623

1266

Hazardous

Hazardous

Hazardous

Hazardous

619,620

600-610, 945

627-642, 886-888, 929, 930
Analyzed for TCLP resulated analytes-Faile

Benzene

Analyzed for TCLP rogulated analytas-Fails Trichloroethene

Analyzed for TCLP regulated analyteo-Fails Bencene and Trichloroethene

Anslyzed for TCLP regulated analytee-Fails Benzene Fails Isnitability Flaoh pt. $=<140^{\circ} \mathrm{F}$

Analyzed for TCLP regulated analytesDecinion made to casi hazardous

Analyzed for TCLP regulated analytes-Fails As

Analyzed for TCLP regulated enalytes-Fails Benzene

Anelyzed for TCLP regulated enalytesDecision made to call hazardous 
Table 45. Hazard Claselfication of the North Site Composite Groups (continued)

\begin{tabular}{|c|c|c|c|}
\hline $\begin{array}{l}\text { Product Stream/ } \\
\text { Composite Group }\end{array}$ & $\begin{array}{l}\text { Containers } \\
\text { Represented }\end{array}$ & $\begin{array}{l}\text { Hazard } \\
\text { Classification }\end{array}$ & Comments \\
\hline \multicolumn{4}{|l|}{ Unlonown Matariale } \\
\hline Pollote & $818-620,652$ & Nonhazardow & $\begin{array}{l}\text { Passes TCLP } \\
\text { Extraction for } \\
\text { Motale; GC } \\
\text { analyais ahows } \\
\text { no organics }\end{array}$ \\
\hline Unknown Liquid & 498 & Nonhazardous & $\begin{array}{l}\text { Analyzed for } \\
\text { TCLP regulated } \\
\text { annlytw; Major } \\
\text { component is } \\
\text { NaCl; pH = } 6.3\end{array}$ \\
\hline Unknown Material & 892, 993 & Hezardous & $\begin{array}{l}\text { Solvent } \\
\text { Contain 4,200 } \\
\text { ppm Bonzene \& } \\
13 \text { ppm Pb }\end{array}$ \\
\hline $\begin{array}{l}\text { SAI Comp } \\
\text { Material-Liquid }\end{array}$ & 1067,1068 & Nonhazardous & $\begin{array}{l}\text { Analyzed for } \\
\text { TCLP regulated } \\
\text { analytea; Major } \\
\text { component is } \\
\mathrm{NaNO}_{3} ; \\
\mathrm{pH}=8.1\end{array}$ \\
\hline $\begin{array}{l}\text { SAI Comp } \\
\text { Material-Solid }\end{array}$ & 1140 & Nonhazardous & $\begin{array}{l}\text { Analyzed for } \\
\text { TCLP regulated } \\
\text { analytes; Major } \\
\text { component is } \\
\mathrm{Na}_{2} \mathrm{SO}_{4}\end{array}$ \\
\hline Artic 76/90 & 868,864 & Hazardous & Dicsel Fuel \\
\hline $\begin{array}{l}\text { Chlorinated } \\
\text { Solvents }\end{array}$ & 1074 & Hezardous & \\
\hline
\end{tabular}

\section{Chemicals}

SAI Comp
Material-Liquid

Monoethanolamine $487 \quad$ Hezardous

Trotolite $\quad 852,617 \quad$ Hazardous 
Table 46. Hazard Claseification of the North Site Composite Groups (continued)

\begin{tabular}{llll}
\hline $\begin{array}{l}\text { Product Stroam } \\
\text { Composito Group }\end{array}$ & $\begin{array}{l}\text { Containers } \\
\text { Ropresentod }\end{array}$ & $\begin{array}{c}\text { Hazard } \\
\text { Classification }\end{array}$ & Comments \\
\hline
\end{tabular}

Chemicaln (continued)

Cauntic Soda

803,804

Nonhazardous

60\% Aqueous

NaOH; Analyzed

for TCLP

rosulated

enalytes

$\mathrm{pH}=7.7$

Boiler Wator

805

Nonhazardous

Treatment

Dry Water

Treatmont-1

808

Nonhazandous

Analyzed for TCLP rogulated enalytes; Major component is $\mathrm{Na}_{2} \mathrm{SO}$; $\mathrm{pH}=12.1$

Analyzed for TCLP regulated analyteo; Major componont is $\mathrm{Na}_{2} \mathrm{SO}_{4}$

Dry Water

Treatment-2

807,808

Nonhazardous

Anelyzed for TCLP regulated analytea; Major component is $\mathrm{Na}_{2} \mathrm{SO}_{4}$ $\mathrm{pH}=6.5$

Soda Ash

Nonhazardous

$\mathrm{Na}_{2} \mathrm{CO}_{3}$ 

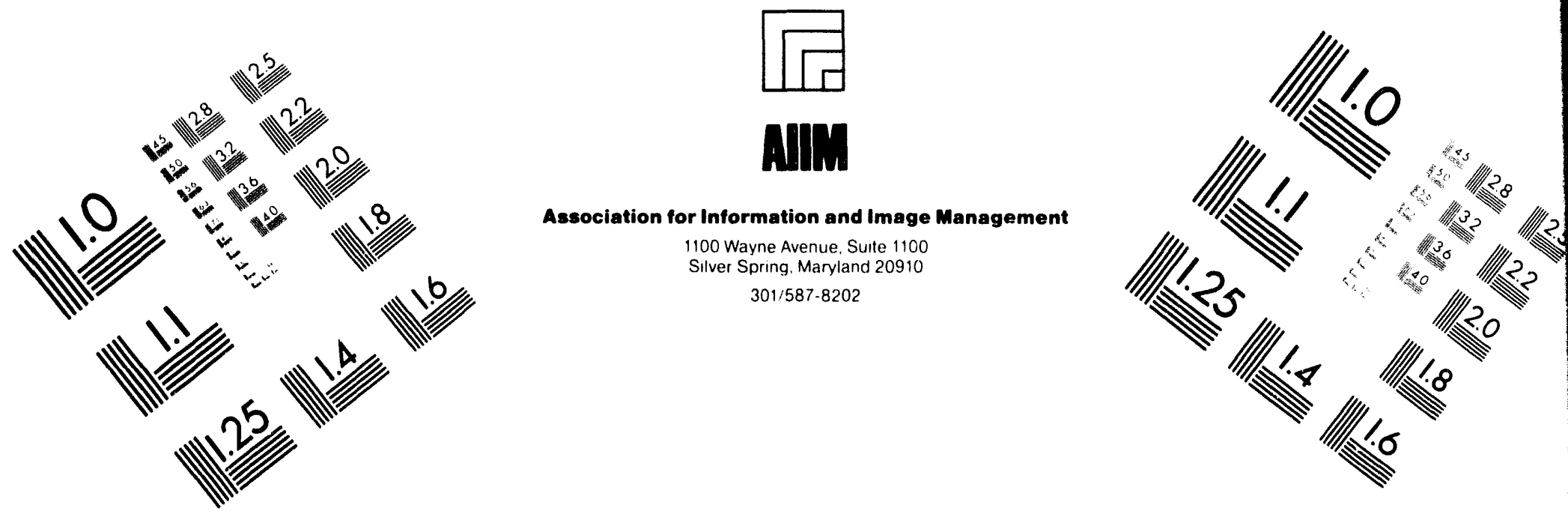

\section{Centimeter}

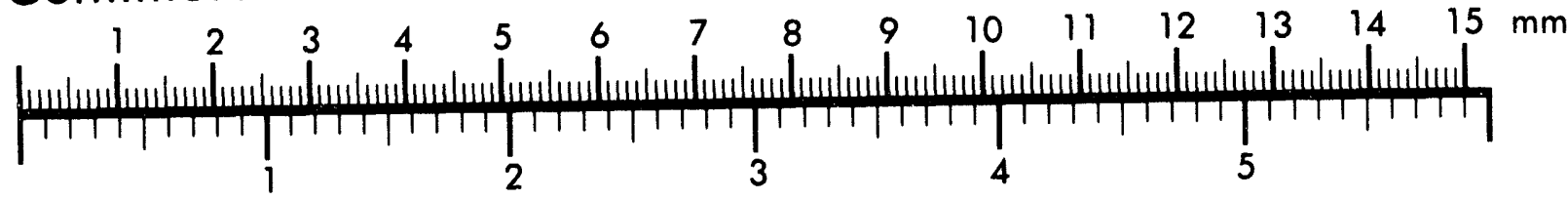

Inches
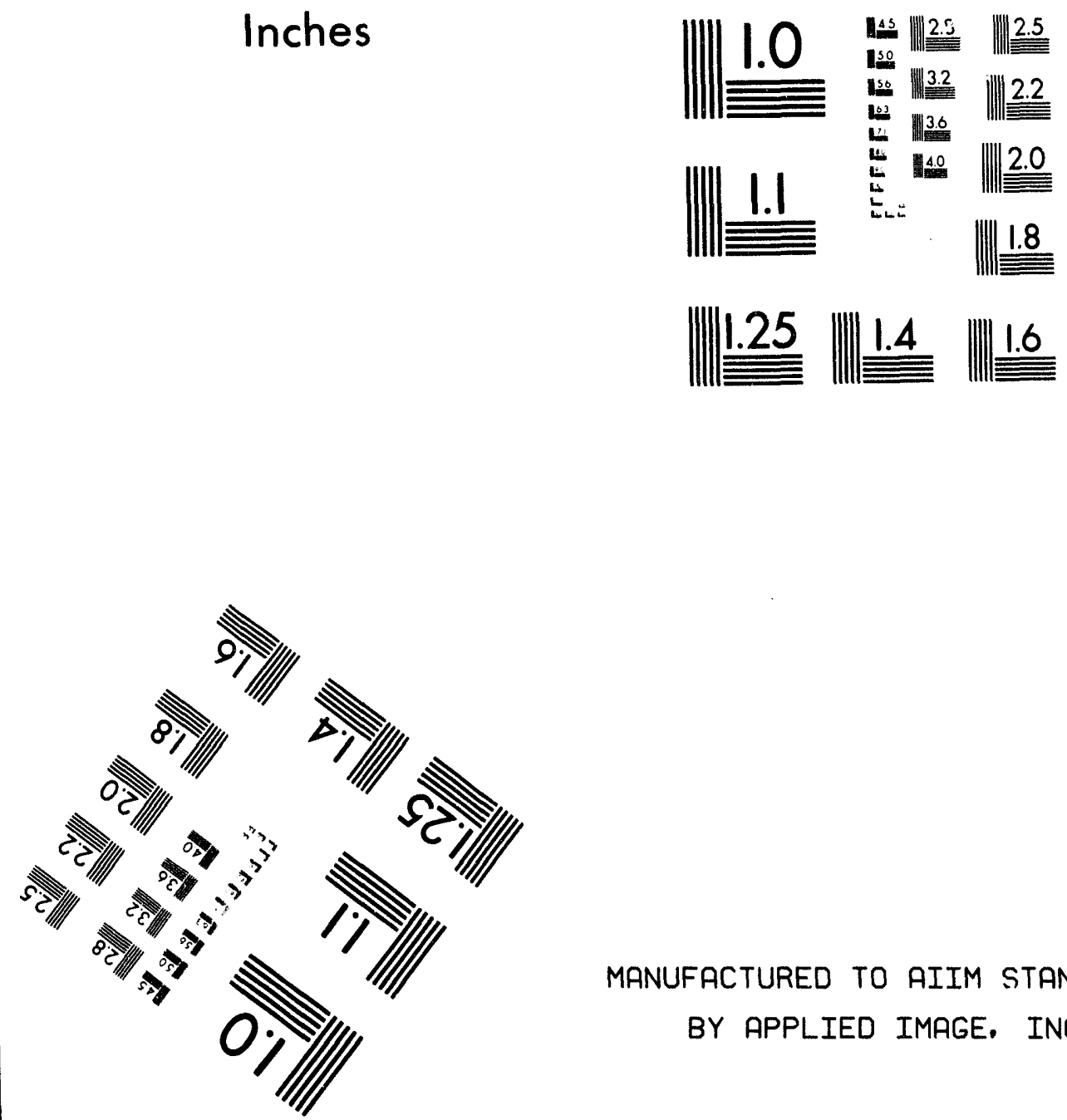

MANUFACTURED TO AIIM STANDARDS

BY APPLIED IMAGE. INC.

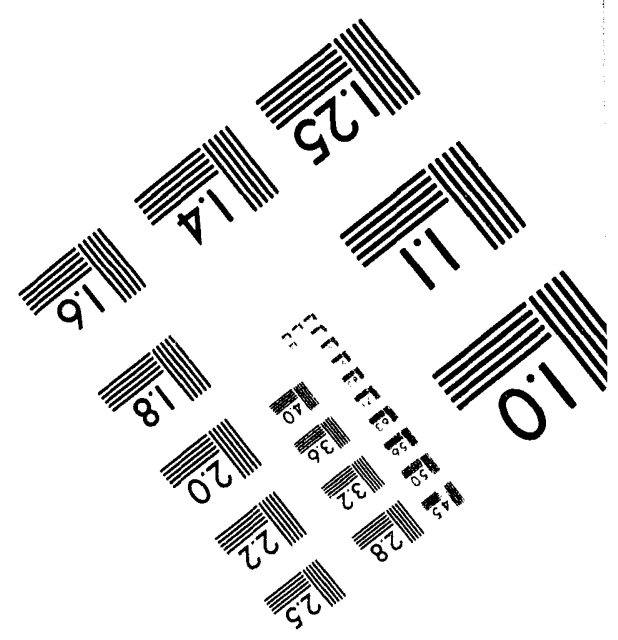



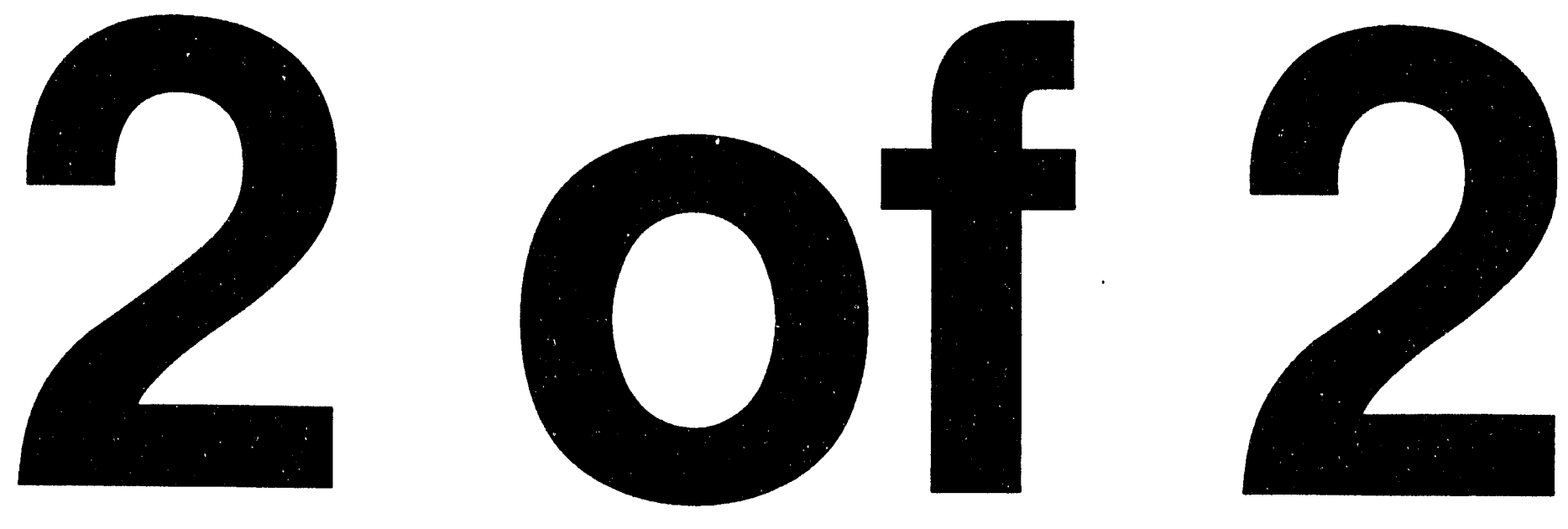


\section{NORTH SITE MATERIALS BANDIING DATA BASE}

As mentioned, the North Site Materials Handling Data Base was created as a quick and accurate means for producing reports on the status of the cleanup project. The system is written in FoxPro 2.0, which is based on a superset of the dBase language. It consists of five primary and two helper data base files. The function of each of these is summarized below. The capitalized letters in the file descriptions are field names.

\section{North Site Materials FYle (EATMAT.DBF)}

This file contains a record for each container of material requiring disposal or use. Each record contains the container's serial number (SERIAL_NO), common name of the material (COMMN_NAME), location (LOCATION), project account number under which the material was generated (ACCT_NO), last name of the project manager (PROJ_MNGR), hazard classification (ËPA Hazardous Waste Number; HAZ_CLASS), container type (CONTAINER), container volume in gallons, (CONT VOLUM), quantity in pounds (QTY LBS), storage environment (STRG_ENVIR), date material was accumulated (ĀCCUMULATED), date material came on site (DATEONSITE), date material was last inspected (LAST_INSPEC), process by which the material was created (WRI_USE), product stream identification number (PRDCTSTRM), composite group identification (COMPGROUP), and comments (COMMENTS).

The following list gives the identification numbers and descriptions for the CONTAINER, STRG_ENVIR, and PRDCTSTRM fields.

- CONTAINER

1 Plastic

2 Stainless Steel

3 Steel

4 Steel with Plastic Liner

5 Cardboard

- STRG_ENVIR

1 Ambient

- PRDCTSTRM

1 Chemicals

2 Miscellaneous Materials

3 Raw Oil Shales

4 Spent Oil Shale, Processed Tar Sand, Activated Charcoal

5 Tars, Oils, and Hydrocarbon Liquids

6 Unknown Materials

7 Unprocessed Coals

8 Unprocessed Tar Sands

9 Waters 


\section{Composite Group File (COMPGRP.DBF)}

This file contains a record of each composite group in the North Site product streams. Each record contains the composite group's name (NAME), identification number (COMPGROUP), list of serial numbers of the containers in the composite group (SN1 and SN2), the hazard status (FAIL, true if hazardous; ANALYFAIL, true if found hazardous by analysis; FORCEFAIL, true if declared hazardous), and product stream identification number (PRDCTSTRM).

\section{Sample File (SAMPLE.DBF)}

This file contains a record for each sample that was taken during characterization of the North Site materials. Each record contains the sample's identification number (SAMPLE_ID), composite group to which the sample belongs (COMPGRP), sample type (TYPE), date and time the sample was taken (DATE;TIME), sampling method (METHOD), name of sample collector (WHO), comments (INSP_COMM), reference to the sampling and laboratory logbooks (FIELDBOOK, FIELDPAGE; LABBOOK, LABPAGE), types of analyses performed on the sample (QUICK, IGNITABILITY, CORROSIVITY, REACTIVITY, TCLP_FULL, TCLP_PART, TOTAL_CHAR, SEMI_QUANT, BTU_CHARAC), related samples (REL_SAMPLE), serial number of the container sampled (SERIAL_NO), and quantity of sample collected (QTY;UNITS).

Each sample identification number consists of the logbook number and logbook page number where the sample is described, followed by either the serial number of the container sampled, or for extracts, composite samples, and blanks, a number assigned to the material. In the data base, a "normal" sample refers to the sample collected at the North Site, and "related" samples are the composite sample to which it was added, a split of the sample, and/or its TCLP extract. The identification numbers and descriptions of the TYPE, METHOD, and WHO fields are listed below.

- TYPE

$\begin{array}{ll}1 & \text { Field Blank } \\ 2 & \text { Normal } \\ 3 & \text { Split } \\ 4 & \text { Equipment Blank } \\ 5 & \text { Method Blank } \\ 6 & \text { Composite } \\ 7 & \text { Extract }\end{array}$


- METHOD

$\begin{array}{ll}1 & \text { Auger } \\ 2 & \text { Coliwasa } \\ 3 & \text { Dipper } \\ 4 & \text { Scoop } \\ 5 & \text { Shovel } \\ 6 & \text { Thief } \\ 7 & \text { Trier } \\ 8 & \text { Weighted Bottle } \\ 9 & \text { Scissors } \\ 10 & \text { Drum Handler Drained from Valve } \\ & \\ \text { WHO }\end{array}$
1 Gitke, Les
2 Sorini, Susan

Analysis File (ANALYSIS.DBF)

This file contains a record for each analysis performed on the samples in SAMPLE.DBF. Each record contains the analysis identification (ANALY_ID, computer generated), identification number of the sample (SAMPLE_ID), analysis type (ANALYTYPE), a nalytical method (ANALYMETH), laboratory identification (WHERE), date analysis was performed (DATE), name of analyst (WHO), notebook reference to sample analysis (LABBOOK;LABPAGE), quantity analyzed (QTY;UNITS), whether the sample passes hazardous waste criteria based on results from analysis (PASS, true indicates nonhazardous), whether the sample is a matrix spike (MATRIXSPIK, true indicates that it is a spike), the identification number of the associated matrix spike (MATRIXTEST), and comments (COMMENTS).

The identification numbers and descriptions for the WHERE, ANALYMETH, and ANALYTYPE are given below.

- WHERE
1 Pace
2 Silver Valley Labs
3 Western Research Institute 
- ANALYMETH

$\begin{array}{ll}1 & \text { ASTM D2015 } \\ 2 & \text { ASTM D240 } \\ 3 & \text { ASTM D3050,D3683,D3684 } \\ 4 & \text { ASTM D93 } \\ \text { 5 } & \text { EPA 1311 } \\ 6 & \text { EPA 3010,3050, \& 6010 } \\ 7 & \text { EPA 3580,8000 } \\ 8 & \text { EPA 7.3.3.2 \& 7.3.4.2 } \\ 9 & \text { EPA 9040 } \\ 10 & \text { EPA 200.7 } \\ 11 & \text { EPA 8240 } \\ 12 & \text { EPA 8250 } \\ 13 & \text { ASTM 3684, 7.1-7.6/7470 } \\ 14 & \text { ASTM 3684, 7.1-7.6/7060 } \\ 15 & \text { ASTM 3684, 7.1-7.6/7740 } \\ 16 & \text { EPA 3050/6010 } \\ 17 & \text { EPA 7471 } \\ 18 & \text { EPA 3050/7060 } \\ 19 & \text { EPA 3050/7740 } \\ 20 & \text { EPA 3050/6010 } \\ 21 & \text { EPA 7470 } \\ 22 & \text { EPA 3010/6010 }\end{array}$

- ANALYTYPE

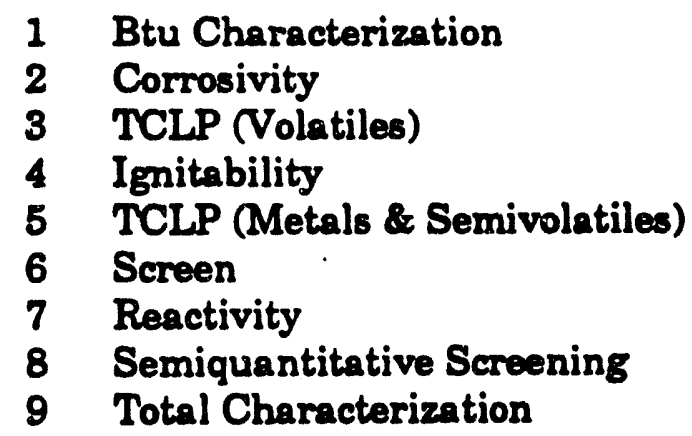

\section{Results File (RESULTS.DBF)}

This file contains a record for each analyte for which testing was conducted. Each record contains the analytical identification number (ANALY_ID), name of the analyte (LABEL), quantity of analyte found (QTY;UNITS), and whether the value for the analyte passes or fails the hazardous criteria (PASS_HWNO, if pass, this is set to PASS; if fail, this is set to the EPA Hazardous Waste Number; if inconclusive, this is set to ????). 


\section{Rexulatory Analyte File (REGLEVELDBF)}

This file contains a record for each TCLP regulated analyte. Each record contains the analyte's name (LABEL), abbreviation (ABBREV), low and high limits (LOWLIMIT;HILIMIT), EPA Hazardous Waste Number (EPAHWNO), units of the limits (UNITS), and three fields used for internal data base operations (TYPE, ORDER, LNMTT).

\section{Label File (POPUP.DBF)}

This file contains the various labels and associated identification symbols described for the data bases.

\section{Data Base Reports}

Reports providing various types of information can be generated using the North Site Materials Handling Data Base. Information that can be generated includes container inventory, which is Appendix $A$ of this report (serial number and material name), testing results by product stream (product stream, composite group, hazard classification, failing characteristic, analyte, and quantity found), failing containers (includes composite groups to which the containers belong), and passing containers (also includes composite groups to which the containers belong). Examples of data base reports for phase I of the North Site cleanup project are included in Appendix $\mathbf{F}$. 


\section{DISCLADMIER}

Mention of specific brand names or models of equipment is for information only and does not imply endorsement of any particular brand. 


\section{REFERENCES}

American Society for Testing and Materials, 1983, D-2015, Standard Test Method for Gross Calorific Value of Solid Fuel by the Adiabatic Bomb Calorimeter. Vol. 05.05: 326-331.

American Society for Testing and Materials, 1983, D-3684, Standard Test Method for Total Mercury in Coal by the Oxygen Bomb Combustion/Atomic Absorption Method. Vol. 05.05: 465-468.

American Society for Testing and Materials, 1988, D.93, Standard Test Method for Flash Point by Pensky-Martens Closed Tester. Vol. 05.01: 31-37.

American Society for Testing and Materials, 1988, D-240, Standard Test Method for Heat of Combustion of Liquid Hydrocarbon Fuels by Bomb Calorimeter. Vol. 05.01: 157-161.

American Society for Testing and Materials, 1988, D-3278, Test Methods for Flash Point of Liquids by Setaflash-Closed-Cup Apparatus. Vol. 06.03.

Code of Federal Regulations, 1992, Protection of the Environment. 40 Part 260, Office of the Federal Register.

Code of Federal Regulations, 1992, Protection of the Environment. 40 Part 261, Office of the Federal Register.

Code of Federal Regulations, 1992, Transportation. 49 Part 173, Office of the Federal Register.

Merriam, N., and S. Sorini, 1993, Project Management Plan for Phase I of North Site Facility Cleanup: Definition of Waste Streams. W/RI Report WRI-93R036.

National Association of Corrosion Engineers, 1972, NACE Standard TM-01-69. Testing of Metals for the Process Industries, NACE, 3400 West Loop South, Houston, TX 77027.

Resource Conservation and Recovery Act, 1984, 3001(g), 42 U.S.C. 6921(g).

U.S. EPA, 1986, Chapter Nine-Sampling Plan. Test Methods for Evaluating Solid Waste: Physical/Chemical Methods (SW-846), Vol. 2, Part 3.

U.S. EPA, 1986, Method 7.3.3.2: Test Method to Determine Hydrogen Cyanide Released from Wastes. Test Methods for Evaluating Solid Weste: Physical/Chemical Methods (SW-846), Vol. 1C, 3rd Ed.

U.S. EPA, 1986, Method 7.3.4.2: Test Method to Determine Hydrogen Sulfide Released from Wastes. Test Methods for Evaluating Solid Waste: Physical/Chemical Methods (SW-846), Vol. 1C, 3rd Ed. 
U.S. EPA, 1986, Method 1110: Corrosivity Toward Steel. Test Methods for Evaluating Solid Waste: Physical/Chemical Methods (SW-846), Vol. 1C, 3rd Ed.

U.S. EPA, 1986, Method 3010: Acid Digestion of Aqueous Samples and Extracts for Total Metals for Analysis by Flame Atomic Absorption Spectroscopy or Inductively Coupled Plasma Spectroscopy. Test Methods for Evaluating Solid Waste: Physical/Chemical Methods (SW-846), Vol. 1A, 3rd Ed.

U.S. EPA, 1986, Method 3050: Acid Digestion of Sediments, Sludges, and Soils. Test Methods for Evaluating Solid Waste: Physical/Chemical Methods (SW-846), Vol. 1A, 3rd Ed.

U.S. EPA, 1986, Method 3580: Waste Dilution. Test Methods for Evaluating Solid Waste: Physical/Chemical Methods (SW-846), Vol. 1B, 3rd Ed.

U.S. EPA, 1986, Method 3640: Gel-Permeation Cleanup. Test Methods for Evaluating Solid Waste: Physical/Chemical Methods (SW-846), Vol. 1B, 3rd Ed.

U.S. EPA, 1986, Method 6010: Inductively Coupled Plasma Atomic Emission Spectroscopy. Test Methods for Evaluating Solid Waste: Physical/Chemical Methods (SW-846), Vol. 1A, 3rd Ed.

U.S. EPA, 1986, Method 7060: Arsenic (Atomic Absorption, Furnace Technique). Test Methods for Evaluating Solid Waste: Physical/Chemical Methods (SW. 846), Vol. 1A, 3nd Ed.

U.S. EPA, 1986, Method 7470: Mercury in Liquid Waste (Manual Cold-Vapor Technique). Test Methods for Evaluating Solid Waste: Physical/Chemical Methods (SW-846), Vol. 1A, 3rd Ed.

U.S. EPA, 1986, Method 7740: Selenium (Atomic Absorption, Furnace Technique). Test Methods for Evaluating Solid Waste: Physical/Chemical Methods (SW. 846), Vol. 1A, 3rd Ed.

U.S. EPA, 1986, Method 8000: Gas Chromatography. Test Methods for Evaluating Solid Waste: Physical/Chemical Methods (SW-846), Vol. 1B, 3rd Ed.

U.S. EPA, 1986, Method 8240: Gas Chromatography/Mass Spectrometry for Volatile Organics. Test Methods for Evaluating Solid Waste: Physical/Chemical Methods (SW-846), Vol. 1B, 3rd Ed.

U.S. EPA, 1986, Method 9040: pH Electrometric Measurement. Test Methods for Evaluating Solid Waste: Physical/Chemical Methods (SW-846), Vol. 1C, 3rd Ed. 
U.S. EPA, 1989, Method 300.2: The Determination of Inorganic Anions in Water by Ion Chromatography. Methods for Chemical Analysis of Water and Wastes, U.S. EPA Report EPA/600/4-79/020.

U.S. EPA, 1990, Toxicity Characteristic Leaching Procedure (Method 1311). Federal Register, March 29, 55: 11798-11877. 

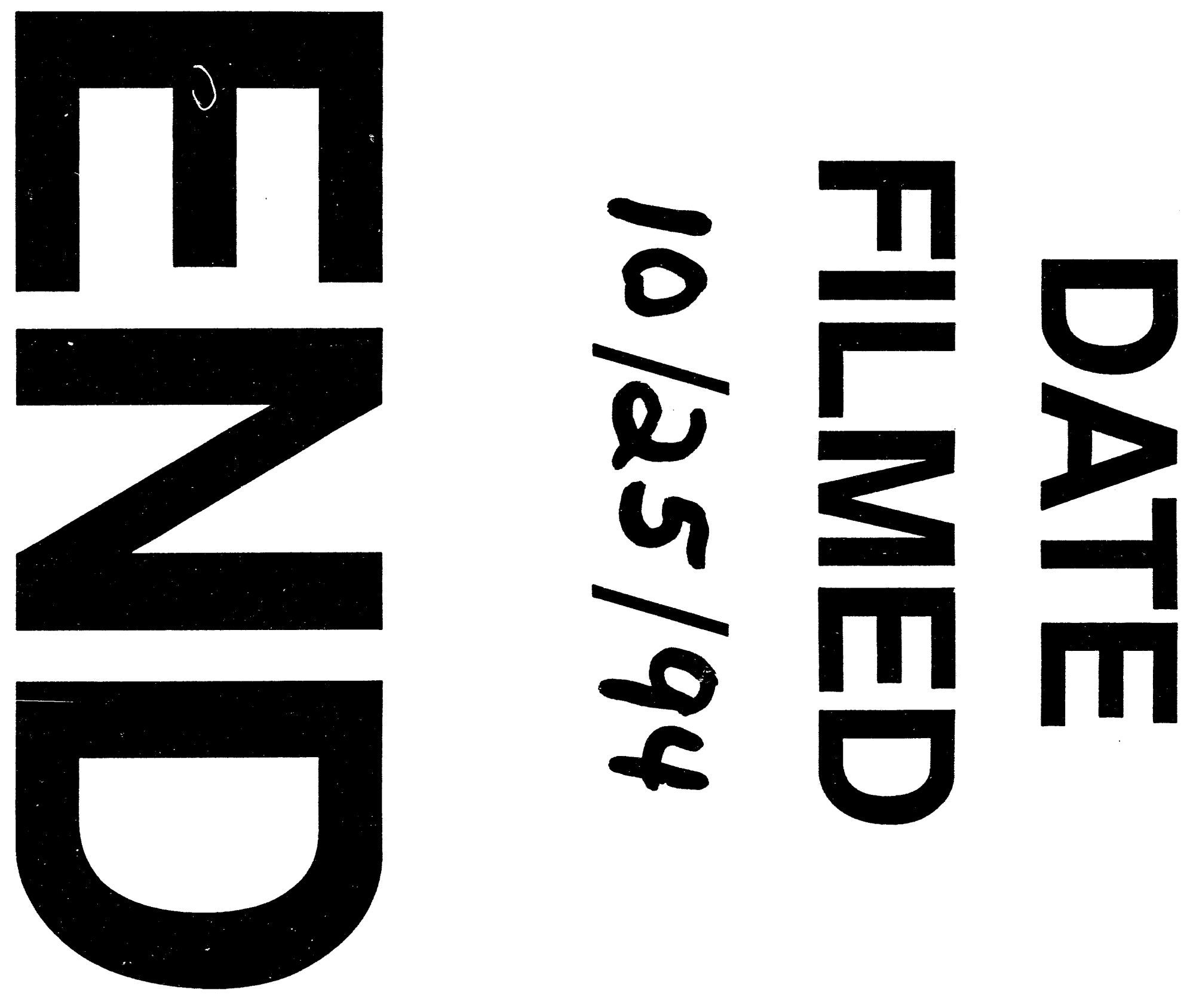
